\title{
An Analysis to Develop a Program for Energy-Integrated Farm Systems
}

September 1981

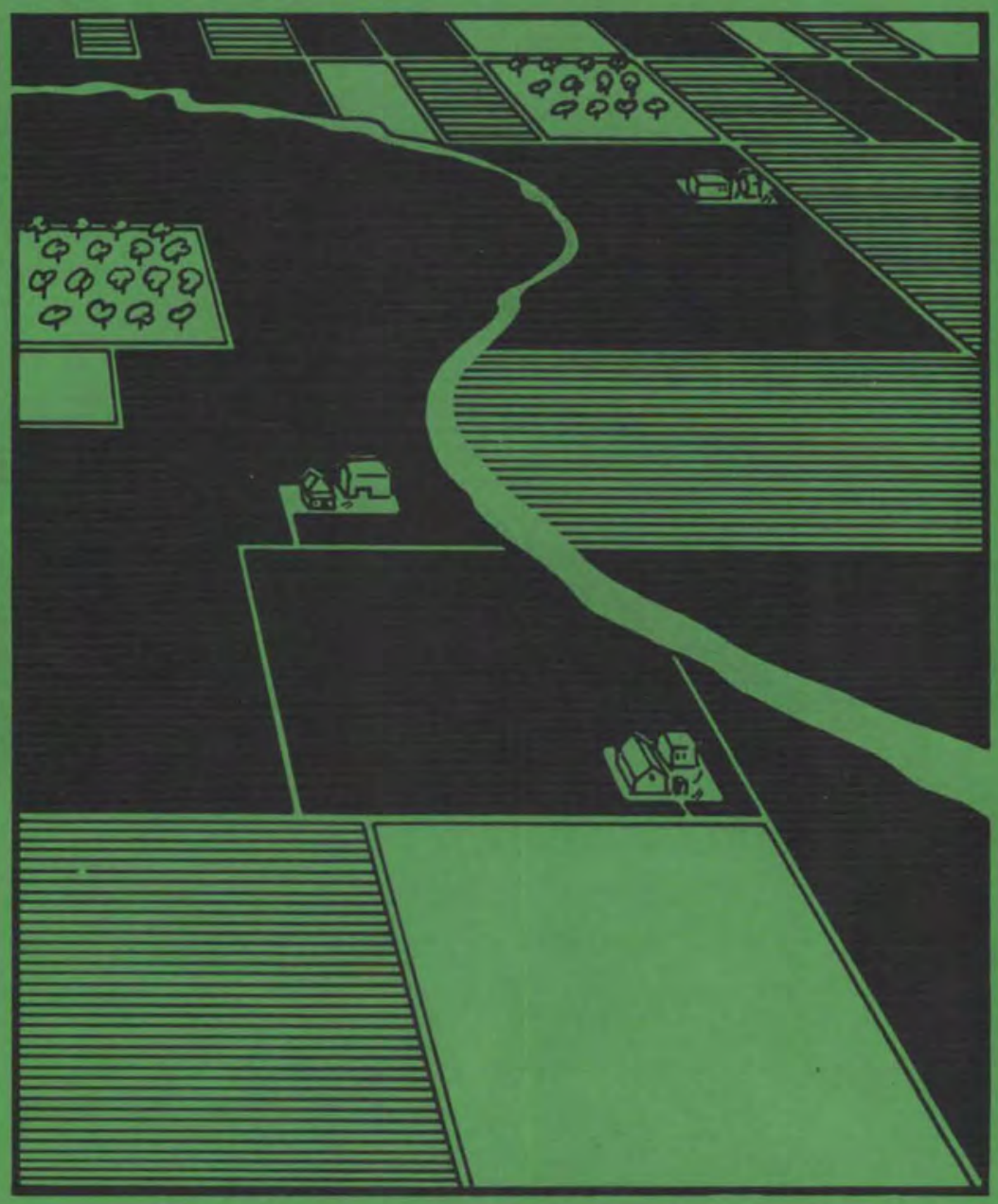

Prepared for the U.S. Department of Energy under Contract DE-AC06-76RLO 1830

Pacific Northwest Laboratory Operated for the U.S. Department of Energy by Battelle Memorial Institute 
PNL-3981

UC-93

AN ANALYSIS TO DEVELOP A PROGRAM FOR ENERGYINTEGRATED FARM SYSTEMS

D. E. Eakin

M. A. Clark

L. K. Inaba

K. I. Johnson

September 1981

Prepared for

the U.S. Department of Energy

under Contract DE-ACO6-RLO 1830

Pacific Northwest Laboratory

Richland, Washington 99352 



\section{CONTENTS}

CHAPTER 1

PURPOSE OF THE RESEARCH

CHAPTER 2

AN ANALYSIS OF EXISTING ENERGY USE PATTERNS . . . . . . . . . . 5

AGRICULTURAL PRODUCTION REGIONS • $\cdot$ • $\cdot \cdot \cdot \cdot \cdot \cdot \cdot \cdot \cdot \cdot \cdot 6$

ENERGY CONSUMPTION OF U.S. AGRICULTURE •

ENERGY CONSUMPTION FOR CROP PRODUCTION

Regional Energy Consumption by Commodity . . . . . . . 11

Geographic Distribution of Fuel Use . . . . . . . 15

Regional Energy Use by Farm Function . . . . . . . 15

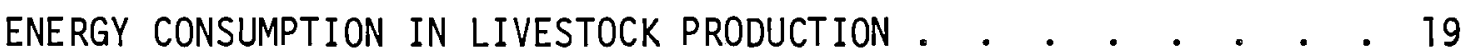

Regional Energy Consumption by Operation and Livestock

Type . . . . . . . . . . . . . . . . . . 19

Energy in Beef Cattle Production . . . . . . . . . 22

Energy in Dairy Production . . . . . . . . . . . 22

Energy in Poultry (Broiler) Production . . . . . . . 25

Energy in Swine Production . . . . . . . . . . 25



CHAPTER 3 •

AN ANALYSIS OF AVAILABILITY OF RENEWABLE RESOURCES . . . . . . . . 31

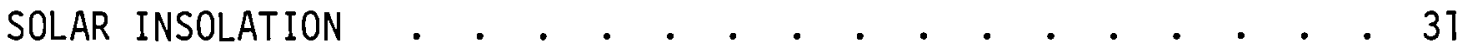

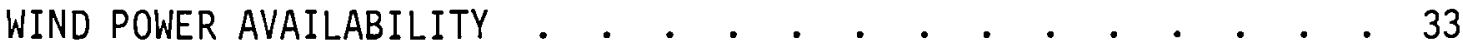

ON-FARM STREAM FLOW AVAILABILITY . . . . . . . . . . 39

GEOTHERMAL ENERGY AVAILABILITY . . . . . . . . . . . . 40

BIOMASS AVAILABILITY . . . . . . . . . . . . . . . . 40

CONCLUSION . . . . . . . . . . . . . . . . . . 44

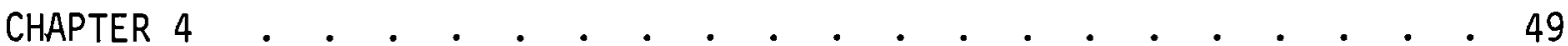

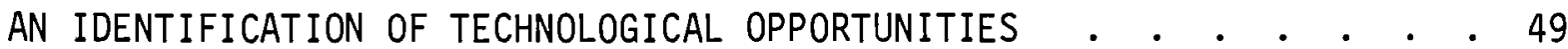

A REVIEW OF THE TECHNOLOGIES APPLICABLE TO ENERGY INTEGRATED

FARM SYSTEMS (EIFS) • • . . . . . . . . . . . . . . 49

Solar . . . . . . . . . . . . . . . . 50

Wind . . . . . . . . . . . . . . . . . 51

Low-Head Hydro . . . . . . . . . . . . . . 56 
(Contents Cont'd)

Geothermal . . . . . . . . . . . . . . 59

Biomass Technologies . . . . . . . . . . . 60

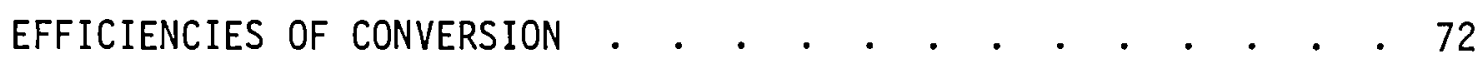

THE TECHNOLOGICAL OPPORTUNITY FOR CANDIDATE EIFS TECHNOLOGIES • 73

CHAPTER 5 .

AN INITIAL DESIGN FOR A NATIONAL PROGRAM OF ENERGY INTEGRATED FARM

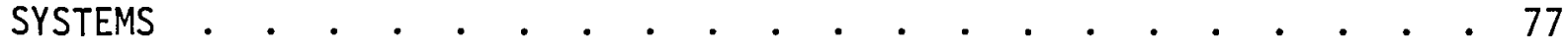

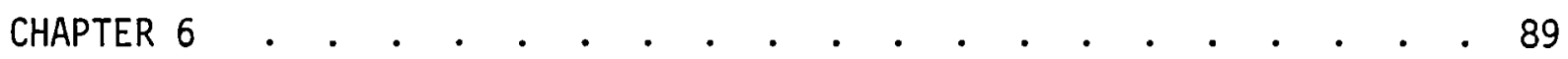

ACCEPTABILITY OF INTEGRATED FARM SYSTEMS TO OWNERS/USERS AND

INSTALLATION AND MAINTENANCE PERSONNEL . . . . . . . . . . . . . 89



Gasoline . . . . . . . . . . . . . . . . . 90

THE ATTITUDES OF THOSE WHO OWN, USE, INSTALL AND MAINTAIN

THE EIFS $\cdot \cdot \cdot \cdot \cdot \cdot \cdot \cdot \cdot \cdot \cdot \cdot \cdot \cdot \cdot \cdot \cdot \cdot \cdot \cdot \cdot \cdot \cdot \cdot \cdot \cdot \cdot 99$

SUMMARY OF THE TECHNOLOGICAL ACCEPTABILITY OF THE EIFS . . . . 101

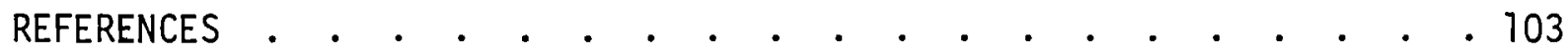

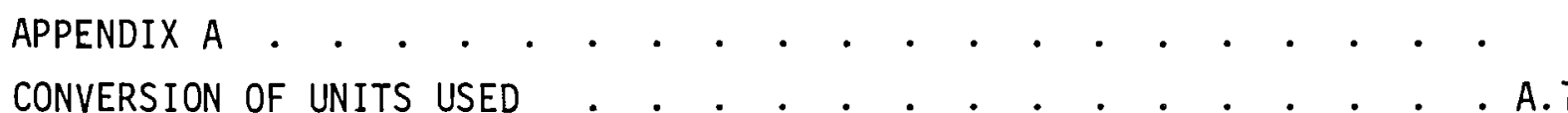

APPENDIX B 


\section{FIGURES}

2.1 Agricultural Production Regions . . . . . . . . . . . 7

2.2 Distribution of Energy in U.S. Agriculture by Energy Form . . 12

3.1 Annual Average Wind Power $\left(\mathrm{W} / \mathrm{m}^{2}\right)$ at $50 \mathrm{~m}$ (Elliott 1977) . . 35

3.2 Surmer - Average Wind Power $\left(\mathrm{W} / \mathrm{m}^{2}\right)$ Estimated at $50 \mathrm{~m}$ above Exposed Areas (E1liott 1977). Over mountainous regions, the estimates are lower limits expected for exposed mountain tops and ridges... . . . . . . . . . . . . . . . 37

4.1 Wind Energy Conversion Systems . . . . . . . . . . 52

4.2 Estimated Low-Head Hydro Capital and Generating Costs as a Function of Plant Capacity. . . . . . . . . . . . . 58

4.3 Possible Products from Agricultural Residues . . . . . . . 61

4.4 Combustion of Residues for Energy . . . . . . . . . . 64 


\section{$\underline{\text { TABLES }}$}

2.1 Total Energy Input to U.S. Crop Production by Farm Function, 1978 .

2.2 Total Energy Input to U.S. Livestock Production by Operation, 1978 . . . . . . . . . . . . . . . . 12

2.3 Energy Input to Production Agriculture by Commodity, 1974 • . 13

2.4 Energy Inputs to Produce Eight Commodities in Eight Regions 1974 (Billion Btu's) . . . . . . . . . . . . . . . 14

2.5 Energy Input in Thousand Btu per Ton Yield for Eight Commodities Produced in Eight Regions for 1974 . . . . . . 16

2.6 Yield in Tons per Acre for Six Commodities Produced in Eight Regions, 1974 . . . . . . . . . . . . . . . . . 17

2.7 Geographic Distribution of Fuel Use for Eight Major Commodities and Eight Regions in Billions Btu's, 1974 . . . . . . . . 18

2.8 Energy Input by Farm Function and Region for Crop Production 1978 (Billion Btu's). . . . . . . . . . . . . . 20

2.9 Energy Input by Livestock Type and Region, 1974 (Billion Btu's) 21

2.10 Energy Input by Operation and Region for Livestock Production 1978 (Billion Btu's). . . . . . . . . . . . . . 23

2.11 Beef Production Energy Requirements . . . . . . . . . 24

2.12 Dairy Production Energy Requirements . . . . . . . . . 26

2.13 Energy Requirements for Poultry Production . . . . . . . 27

2.14 Energy Requirements for Swind Production . . . . . . . . 27

3.1 Daily Averages of Solar Energy Received on a Horizontal Surface -- Monthly . . . . . . . . . . . . . . . 32

3.2 An Estimate of the Available Solar Energy During the Mean Farming Season, by Region . . . . . . . . . . . 34

3.3 Expected Available Wind Power $\left(W / \mathrm{m}^{2}\right)$ at Farm Elevation

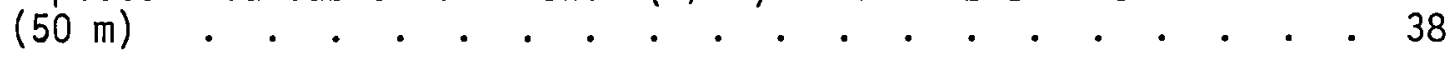

3.4 Percent of Farm Available as Wind Energy . . . . . . . . 38

3.5 Estimate of the Available On-Farm Stream Flow Energy During the Mean Farming Season, by Region . . . . . . . . . . 41

3.6 Estimate of the Available Geothermal Energy During the Mean Farming Season, by Region... . . . . . . . . 41

3.7 Typical Agricultural Residue Yields . . . . . . . . . . 42

3.8 Approximate Total Crop and Other Renewable Residues Developed in the USA . . . . . . . . . . . . . . . . . . . . 42

3.9 An Estimate of the Biomass Energy Available Annually by Region . 43 
(Tables cont'd)

3.10 Energy Availability by Conversion of Major U.S. Crops to Ethanol

3.11 Potential Contribution by Various Resources to Energy-Integrated Farms Energy Needs (in trillion Btu's). . . . . . . . . 46

3.12 Availability of EIFS Resources in Percent of Required Energy . 47

4.1 Energy Recovery Efficiency for Substitution Technology . . . 74

4.2 Percent of End Use Energy Form that Could be Supplied by the Substitution Technologies (Reflects both Stage of Development and Expected Ability to be Feasible) . . . . . . . . . 75

5.1 Total Energy Input by End Use Energy Form for U.S. Crop and Livestock Production, 1978 (from Chapter 2) . . . . . . . 78

5.2 Energy that Could be Supplied by the Substitution Technology (Billion Btu's) . . . . . . . . . . . . . . . . 79

5.3 Region 1 - Billions of Btu's that could be Supplied by the Substitution Technologies (Based on 1974 Energy Needs) . . . 81

5.4 Region 2 - Billions of Btu's that Could be Supplied by the Substitution Technologies (Based on 1974 Energy Needs) . . . 82

5.5 Region 3 - Billions of Btu's that Could be Supplied by the Substitution Technologies (Based on 1974 Energy Needs) . . . 83

5.6 Region 4 - Billions of Btu's that Could be Supplied by the Substitution Technologies (Based on 1974 Energy Needs) . . . 84

5.7 Region 5 - Billions of Btu's that Could be Supplied by the Substitutions Technologies (Based on 1974 Energy Needs) . . . 85

5.8 Region 6 - Billions of Btu's that Could be Supplied by the Substitution Technologies (Based on 1974 Energy Needs) . . . 86

5.9 Region 7 - Billions of Btu's that Could be Supplied by the Substitution Technologies (Based on 1974 Energy Needs) . . 87

5.10 Region 8 - Billions of Btu's that Could be Supplied by the Substitution Technologies (Based on 1974 Energy Needs) . . . 88

6.1 General Characterization of U.S. Farms . . . . . . . . . 91

6.2 Average Value of Farmland and Buildings by Region . . . . . 91

6.3 Average Value of Machinery, Motor Vehicles and Livestock . . . 92

6.4 Land Utilization of U.S. Farmland . . . . . . . . . . 92

6.5 Characterization of U.S. Farm Population (1977) . . . . . . 92

6.6 Livestock by Type on U.S. Farms . . . . . . . . . . . 93

6.7 Energy in Millions of Btu for Various Farm Needs for Example 94

6.8 Quantities of Various Energy Containing Materials Needed on
Example Farms in Each Region 
(Tables cont'd)

6.9 Average Energy Used in Milk Production . . . . . . . . . 96

6.10 Estimated Reaction of Market Participants to Candidate EIFS Technologies . . . . . . . . . . . . . . . 100

B.1 Average Farm Size (Region 1), 159 Acres (Million Btu's/Average Farm) . . . . . . . . . . . . . . . . . . . . B.1

B.2 Average Farm Size (Region 2), 244 Acres (Million Btu's/Average Farm). . . . . . . . . . . . . . . . B.2

B.3 Average Farm Size (Region 3), 219 Acres (Million Btu's/Average Farm) . . . . . . . . . . . . . . . . . B.3

B.4 Average Farm Size (Region 4), 206 Acres (Million Btu's/Average Farm). . . . . . . . . . . . . . . B.4

B.5 Average Farm Size (Region 5), 852 Acres (Million Btu's/Average Farm) . . . . . . . . . . . . . . . . . . . B.5

B.6 Average Farm Size (Region 6), 571 Acres (Million Btu's/Average Farm) . . . . . . . . . . . . . . . B.6

B.7 Average Farm Size (Region 7), 2570 Acres (Million Btu's/ Average Farm) . . . . . . . . . . . . . . B.7

B.8 Average Farm Size (Region 8), 1907 Acres (Million Btu's/ Average Farm) . . . . . . . . . . . . . . . B.8

B.9 Energy in Thousands of Btu's per Milk Cow by Fuel Type . . . B.9 
.

.

. 


\section{CHAPTER 1}

\section{PURPOSE OF THE RESEARCH}

American agriculture is critically dependent on energy. Lack of fuel during planting and harvest seasons can mean the loss of a crop, hungry people and a weakening of an entire economy. The risks of fuel shortages to agriculture are sufficiently high to warrant a national program of energy-integrated farm systems. The purpose of the research presented here is to: 1) establish the objective of the program, and 2) identify guidelines for program development.

Energy-producing technology has resulted in low-cost gas and oil to the American farmer and has allowed him to produce commodities with less labor. Consumers have benefited from this situation with abundant food at low prices. Farmers now rely on a relatively stable world political economy that assures a constant flow of $0 i 1$ and gas at acceptable prices. Rapid curtailment of $0 i 1$ and gas would cause food prices to soar; food shortages would likely develop in the short term. An energy shortfall of $5 \%$ is estimated to result in a $26 \%$ increase in the price of farm commodities (Council for Agricultural Science and Technology 1977). However, the U.S. agricultural economy, with its many relatively small producers, who are tied to a complex system of energy suppliers, and responsible for feeding an entire nation and more, is too complex for anyone to determine the precise impact of an energy shortfall. Those intimately familiar with the agriculture industry feel that the current risk of an energy shortfall to agriculture is too high to go unnoticed at the federal level.

Limits on future technological innovations in the $0 i 1$ and gas industry, the precarious nature of the world petroleum economy and the dependence of our food supply on energy necessitate the use of renewable energy resources and possibly a decentralization of energy systems for agriculture. This need requires answers to several questions.

- Do farmers have sufficient energy from the sun, wind, streams that flow through their fields, and residues of their crops to attain a satisfactory degree of independence from petroleum? 
- Can the same ingenuity that resulted in the recovery of that oil from above the Arctic Circle, below the ocean and the trasnport of that oil to the nation's farms be arranged to give farmers a degree of independence from petroleum?

- Can energy-integrated farm systems that apply available technology to the use of renewable energy sources be developed and thereby increase the certainty that our farms can continue to feed the nation? Such requirements warrant a national program to serve as a focal point for facilitating necessary interaction between the public and private sectors to induce conversation of nonrenewable energy resources through technology transfer at competitive market prices (Walden 1978).

A goal must be established to give the program direction and aid in the judicious allocation of federal funds. The program's objective is determined by: 1) an analysis of the technologies that could be utilized to transform renewable farm resources to energy by the year 2000, 2) the quantity of renewable farm resources that are available and 3) current energy-use patterns.

Generation of the first commercial application of a new or improved process or product can originate in facilities that range from small farm machine shops to large sophisticated laboratories. To reach these sources the Department of Energy issued a program opportunity notice soliciting proposals for projects leading to the commercialization of innovative technology (U.S. Department of Energy 1979). The final selection of projects has been made on the individual merits of specific proposals. However, the efficient expenditure of federal funds necessitates the identification of guidelines to assure that individual projects fit together in a comprehensive national program to meet the established objective.

Individual research, development and demonstration projects are fit into a national program of energy-integrated farm systems on the basis of: 1) market need, 2) conversion potential, 3) technological opportunities, and 4) acceptability. Quantification of these factors for the purpose of establishing program guidelines is conducted using the following four 
precepts: 1) market need is identified by current use of energy for agricultural production; 2) conversion potential is determined by the availability of renewable resources, and 3) technological opportunities are determined by the state-of-the-art methods, techniques and processes that can convert renewable resources into farm energy.

Each of these factors is analyzed in Chapters 2-4. Chapter 5 draws on the analysis of these factors to establish the objective of the program and identify guidelines for the distribution of program funds. Chapter 6 then discusses the "acceptability of integrated farm systems," which can not be quantified like the other factors. 
CHAPTER 2

\section{AN ANALYSIS OF EXISTING ENERGY USE PATTERNS}

American agriculture is not equally dependent on energy throughout its different farming regions. Regions currently having farming practices that are more energy-intensive than others are thought to warrant greater concentration of federal effort in promoting energy-integrated farm systems. This position is predicated on the proposition that energy intensity creates need, which is interpreted as a market for alternative energy technology. Commercialization is higher in firms that devote more of their research and development resources to projects that are designed to satisfy a felt market need rather than designed to find specific uses for promising technology (Mansfield et al., 1977). Therefore, the Department of Energy is believed to probably have a greater impact on the inducement of energy-integrated farm systems if it funded a greater share of research, development, and demonstration in areas where the greatest farm use of energy currently occurs.

A literature review shows no analysis of existing data to identify relative regional energy-use intensity. The standard data bases are Energy and U.S. Agriculture: 1974 Data Base, (U.S. Department of Agriculture 1976) and Energy and U.S. Agriculture: 1974 and 1978, (U.S. Department of Agriculture 1980). These data bases are the source of the data presented in this chapter. Friedrich (1978, p. 161-162) presents suggested energyconservation techniques and analyses and various energy-saving implementation strategies but concludes that differences in geography, climate, politics, economics, and social conditions require policymakers to make appropriate modifications in suggested strategies to maximize social welfare. Dvoskin and Heady (1977) use an interregional linear programming model to determine the response of U.S. agricultural production to various energy supply and price conditions. Lockeretz (1977) analyzes energy use patterns in Northeast farms to determine potential replacement of fossil fuels by energy from renewable resources. He concludes that renewable resources could substitute about $25 \%$ of the on-farm energy use. 
The purpose of the analysis presented in this chapter is to differentiate the nation into regions based on the recognition of the farm energy market and for agricultural production needs. The nation is first divided into production regions, and total energy consumption patterns for both crop and livestock production are discussed by commodity and function. The energy used for crop production is then detailed by major commodity, region, fuel type, farm function and yield. The energy used for livestock production is then reviewed.

\subsection{AGRICULTURAL PRODUCTION REGIONS}

The United States has been divided into eight regions to identify regional energy use in agriculture. These regions are pictorally shown in Figure 2.1. The Northeast and Appalchian Regions were combined to form Region 1. The Southeast and Delta Regions of the U.S. Department of Agriculture groupings were combined to form Region 2 so that total regional energy use among regions would be comparable. Arizona was removed from the Mountain States and combined with California because nearly a11 its agriculture is at low elevations in the warmest climatic zone of the United States and also because Arizona produces crops similar to those grown in Southern California.

\subsection{ENERGY CONSUMPTION OF U.S. AGRICULTURE}

The purpose of this section is to determine the energy use patterns of U.S. agriculture (1ivestock and crop production) by farm function or operation, energy form and commodity. The total energy inputs to livestock and crop by farm function/operation are shown in Tables 2.1 and 2.2, respectively. Crop production uses $1,824,843$ billion BTU's and 1ivestock production 223,179 billion BTU's. Thus livestock production (excluding feed energy input) accounts for only about 11 percent of the energy used in U.S. agriculture while crop production accounts for about 89 percent. The largest energy consumptive function for crop production is for fertilizer, which accounts for 35.8 percent of the energy used. Accounting for 29.4 percent of the energy use, feed handling is the major energy consuming step in livestock production. 


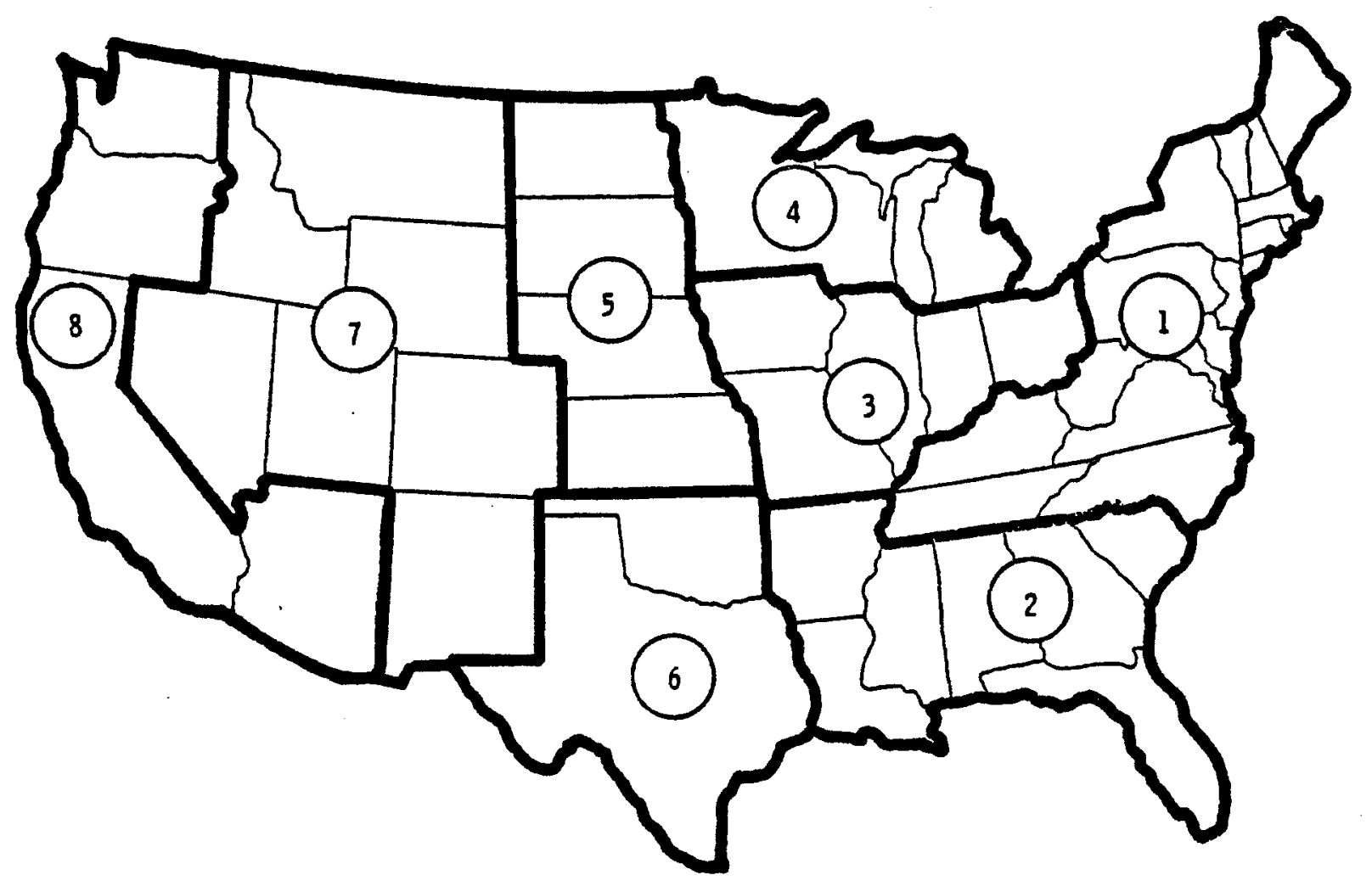

FIGURE 2.1. Agricultural Production Regions 
TABLE 2.1. Total Energy Input to U.S. Crop Production by Farm Function, 1978

Farm Function
Preplant
Plant
Cultivate
Harvest
Farm Pickup
Fertilizer Application
Pesticide Application
Farm Truck
Farm Auto-Crops
Grain Handling (Vehs)
Grain Handling (Mach)
Crop Drying (on-Fm)
Irrigation
Frost Protection
Fertilizer
Pesticides
Electricity
Miscellaneous
Total

\begin{tabular}{cc} 
BTU Total (Billion) & Percent \\
\hline 175537 & 9.6 \\
47870 & 2.6 \\
50031 & 2.7 \\
154755 & 8.5 \\
129559 & 7.1 \\
12996 & 0.7 \\
16937 & 0.9 \\
67732 & 3.7 \\
60767 & 3.3 \\
1905 & 0.1 \\
114 & 0 \\
71364 & 3.9 \\
254766 & 14.0 \\
39824 & 2.2 \\
652532 & 35.8 \\
68130 & 3.7 \\
5783 & 0.3 \\
14232 & $\underline{0.8}$ \\
1824834 & 100
\end{tabular}

Source: U.S. Department of Agriculture 1976. 
TABLE 2.2. Total Energy Input to U.S. Livestock Production by Operation, 1978

\begin{tabular}{lcc} 
Operations-Livestock & BTU Total (Billion) & 2.6 \\
\cline { 2 - 3 } Lighting & 5914 & 29.4 \\
Feed Handling & 65606 & 10.6 \\
Waste Disp. (Vehicles) & 23756 & 0.7 \\
Waste Disp. (Machinery) & 1639 & 3.2 \\
Water Supply & 7174 & 1.1 \\
Livestock Handling & 2536 & 2.6 \\
Space Heating & 5761 & 3.1 \\
Ventilation & 6892 & 4.4 \\
Water Heating & 9745 & 1.2 \\
Milking & 2708 & 2.0 \\
Milk Cooling & 4438 & 0 \\
Egg Handling & 106 & 12.3 \\
Brooding & 27512 & 16.3 \\
Farm Vehicles & 36278 & 3.9 \\
Farm Auto-Lvstk & 8611 & 6.5 \\
Other & $\underline{14505}$ & 100
\end{tabular}

Source: U.S. Department of Agriculture 1976. 
The farm functions and livestock operations have been categorized by energy form as follows: mechanical mobile, mechanical stationary, chemical thermal, electrical and miscellaneous. These categories can then be used to determine how well an energy conversion technology can meet the energy needs of U.S. agriculture. The following groupings of functions and operations were used.

GROUPING OF FUNCTIONS/OPERATIONS BY ENERGY FORM

\section{Energy Form}

Mechanical Mobile

Mechanical Stationary

Thermal

Chemical

Electrical

Miscellaneous

Farm Function

Preplant

Plant

Cultivate

Harvest

Farm Pickup

Fertilizer Applic.

Pesticide Applic.

Farm Truck

Farm Auto-Crops

Grain Handling (Vehs)

Irrigation

Grain Handling (Mach)

Crop Drying

Frost Protection

Fertilizer

Pesticides

Electricity

Miscellaneous
Livestock Operation

Feed Handling Waste Disp (Vehs) Livestock Handling Farm Vehicles Farm Auto-Lvstk
Waste Disp. (Mach)

Water Supply

Ventilation

Milking

Milk Cooling

Egg Handling

Space Heating

Water Heating

Brooding

Lighting

Miscellaneous 
The distribution of energy used in U.S. agriculture by energy form is shown graphically in Figure 2.2. For crop production the two biggest energy forms are chemical and mechanical mobile, which accounts for 39.5 and 39.4 percent of the energy used in crop production, . respectively. Mechanical mobile energy accounts for 61.3 percent of the energy used in livestock production. Thus, the energy conversion technologies should provide mechanical mobile energy (preferably a liquid fuel) and chemical energy (mostly nitrogen fertilizer) to have a large impact on U.S. agriculture energy.

The energy input by commodity for U.S. agriculture is shown in Table 2.3. Corn production is the highest energy consumer, accounting for 27.9 percent of all the energy used for crop production. Cow and calve operations consume 29.5 percent of the energy used for livestock production with milk cows rating second at 23.2 percent.

\subsection{ENERGY CONSUMPTION FOR CROP PRODUCTION}

This section examines the energy used for crop production on a regional basis by commodity, fuel type and function.

\subsubsection{Regional Energy Consumption By Commodity}

The purpose of this section is to determine the intensity of energy use in the production of major energy-using commodities in terms of Btu/ton of product. Production of corn, soybeans, wheat, hay, cotton, and sorghum utilizes $72 \%$ of the energy used to produce crops. These six commodities account for $80 \%$ of the nation's cultivated acres. Corn and sorghum includes both grain and silage, and hay includes alfalfa and other hay.

The amount of energy required to produce the six commodities is shown in Table 2.4. The table shows that corn is the biggest energy user with hay ranking a clear second, followed closely by wheat. Therefore, a high priority should be put on projects relating to the production of these three commodities. The Midwest (Region 3 ) is clearly the big energy-using region. 


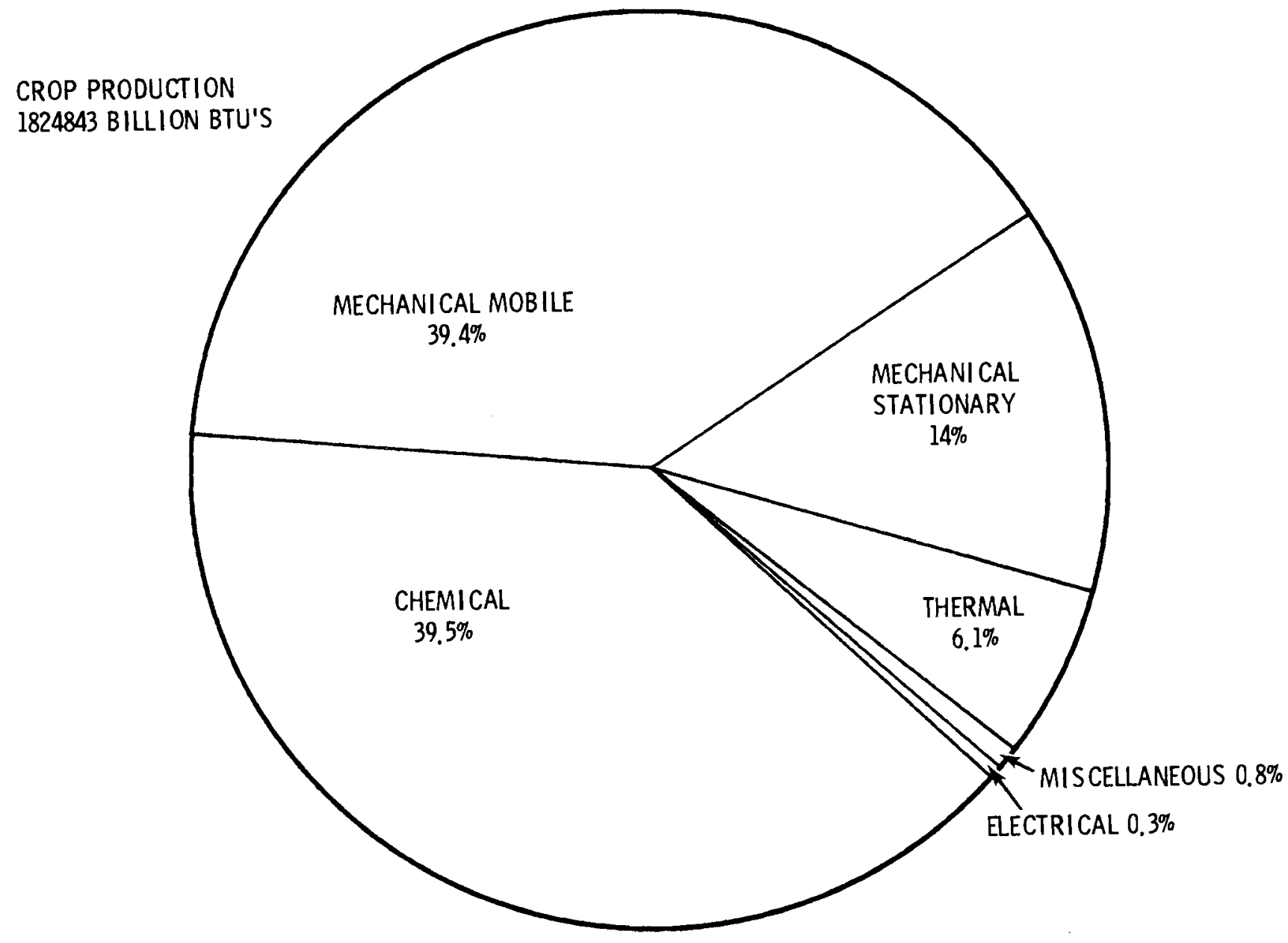

LIVESTOCK PRODUCTION 223179 BILLION BTU'S

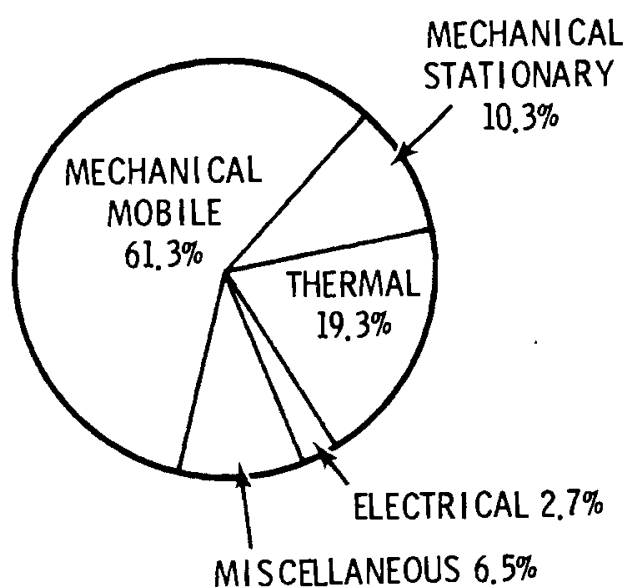

FIGURE 2.2. Distribution of Energy in U.S. Agriculture by Energy Form 


\section{TABLE 2.3. Energy Input to Production Agriculture}

by Commodity, 1974

Crops
Corn
Soybeans
Ninter Wheat
Alfalfa
Corn Silage
Cotton
Grain Sorghum
Vegetables-Fresh
Spring Wheat
Hay-Other
Potatoes
Rice
Sugar Beets
Oats
Flue-Cured Tobacco
Sugar Cane
Vegetables-Process
Barley
Burley Tobacco
Noncitrus-0ther
Peanuts
Oranges
Grapes
Apples
Edible Beans-Dried
Peaches
Seed Crops
Sorghum Silage
Grapefruit
Flaxseed
Lemons
Sweet Potatoes
Shade Tobacco
Citrus-0ther
Rye
Pineapples
Edible Peas-Dried
Unspecified Crops
Unspecified Irrig
Total Crops

Livestock

Beeri-Cows \& Calves Beef-Feedlot

Milk. Cows

Hogs

Chickens-Layers

Chickens-Pullets

Broilers

Turkeys

Sheep \& Lambs

Misc. Poultry

Total-Livestock

Total-Agriculture
Total Btu's (Billion)

499256

126875

158600

121474

77053

148750

101399

23109

42868

79469

28578

45673

15518

32488

36680

13248

26394

26757

7350

14874

128388

40486

7105

13461

10966

6465

5345

5253

7709

2097

2714

1369

311

3408

7323

345

295

2558

33916

1789930

Total 8tu's (Bil1ions)

66096

25585

51981

37149

5639

6146

19974

7174

3703

854

224291

2014221
Percent

27.9

7.1

8.7

6.8

4.3

8.3

5.7

1.3

2.4

4.4

1.6

2.6

0.9

?. 8

2.1

0.7

1.5

1.5

0.4

0.4

0.7

2.3

0.4

0.8

0.6

0.4

0.3

0.3

0.4

0.1

0.2

0.1

0

0.2

0.4

0

0.1

1.9

Percent

29.5

17.4

23.2

16.6

2.5

2.7

8.9

3.2

1.7

0.4

Source: U.S. Department of Agriculture 1976. 
TABLE 2.4. Energy Inputs to Produce Eight Commodities in Eight Regions 1974 (Billion Btu's)

\begin{tabular}{|c|c|c|c|c|c|c|c|c|}
\hline Region & Corn & Soybeans & Wheat & Hay & Cotton & Sorghum & Total & Percent \\
\hline 1 & 53452 & 15331 & 8219 & 34768 & 5894 & 789 & 118453 & 8.6 \\
\hline 2 & 22489 & 32975 & 5326 & 11120 & 54429 & 1850 & 128189 & 9.4 \\
\hline 3 & 264273 & 61173 & 10207 & 31878 & 2949 & 3037 & 373517 & 27.3 \\
\hline 4 & 81208 & 10189 & 11604 & 25830 & -- & -- & 128831 & 9.4 \\
\hline 5 & 111436 & 5592 & 60924 & 37981 & -- & 29965 & 245898 & 17.9 \\
\hline 6 & 14622 & 2596 & 48602 & 8815 & 53733 & 60054 & 188422 & 13.7 \\
\hline 7 & 13138 & -- & 24334 & 27763 & 4911 & 5208 & 75354 & 5.5 \\
\hline 8 & 5964 & -- & 23372 & 23848 & 26786 & 32246 & 112216 & 8.2 \\
\hline Total & 566582 & 127856 & 192588 & 202003 & 148702 & 133149 & 1370880 & 100 \\
\hline
\end{tabular}

Source: U.S. Department of Agriculture 1976. 
One index of energy efficiency is the Btu per ton of output. Energy efficiency calculations for the eight commodities in the eight regions are presented in Table 2.5. This table shows that the most energy-inefficient commodity is cotton in Region 7 . The most energyefficient commodity is sorghum in Region 8. Not much cotton is grown in the Mountain States (Region 7), and the Far West (Region 8) is not particularly noted for sorghum. The yields in tons per acre for these six commodities are shown for each region in Table 2.6.

\subsubsection{Geographic Distribution of Fuel Use}

Table 2.7 shows the six main types of fuel consumed in producing the eight commodities in the eight regions: gasoline, diesel, LP gas, natural gas, electric power, with fuel oil, and coal, listed as "other" fuel. The total of each type of fuel used for a commodity is also shown. Percent of total used in each region is shown at the bottom of the region column.

Table 2.7 can be used to compare consumption by proposed energy conservation and substitution technologies with current consumption for potential benefit evaluation. Table 2.7 shows that corn and hay are the largest users of gasoline, while corn and soybeans are the largest users of diesel. On a regional basis, Region uses the largest amount of gasoline in the production of corn and hay. Regions 3 and 5 use more diesel in the production of corn than any other region.

\subsubsection{Regional Energy Use By Farm Function}

As previously discussed, energy powers agriculture to grow a variety of commodities with varying degrees of energy intensity and with several different kinds of fuel. Each fuel must be considered in designing a National Program of Energy Integrated Farm Systems. However, the program's success will rest on the substitution of renewable farm energy for traditional sources through the functional farm use of that energy. The purpose of this section is to prioritize the functional farm energy uses. 
TABLE 2.5. Energy Input in Thousand Btu per Ton Yield for Eight Commodities Produced in Eight Regions for 1974

\begin{tabular}{|c|c|c|c|c|c|c|c|c|}
\hline \multirow[b]{2}{*}{ Region } & \multicolumn{2}{|c|}{ Corn } & \multirow[b]{2}{*}{ Soybeans } & \multirow[b]{2}{*}{ Wheat } & \multirow[b]{2}{*}{ Hay } & \multirow[b]{2}{*}{ Cotton } & \multicolumn{2}{|c|}{ Sorghum } \\
\hline & Grain & SiTage & & & & & Grain & Silage \\
\hline 1 & 3001 & 458 & 4405 & 3414 & 1687 & 51104 & 2717 & 470 \\
\hline 2 & 3780 & 596 & 6575 & 5341 & 1813 & 50458 & 4494 & 671 \\
\hline 3 & 3457 & 679 & 3116 & 2931 & 1575 & 44655 & 3392 & 547 \\
\hline 4 & 3685 & 668 & 3508 & 1551 & 1227 & $-\cdots$ & ---- & -- \\
\hline 5 & 6867 & 1102 & 3256 & 2984 & 1841 & ---- & 4661 & 889 \\
\hline 6 & 5539 & 1527 & 6847 & 6847 & 1086 & 68757 & 6212 & 885 \\
\hline 7 & 4459 & 618 & ---- & 2809 & 1681 & 116837 & 10742 & 544 \\
\hline 8 & 3595 & 582 & --- & 3219 & 1665 & 30430 & 7027 & 369 \\
\hline
\end{tabular}


TABLE 2.6. Yield in Tons per Acre for Six Commodities Produced in Eight Regions, 1974

\begin{tabular}{|c|c|c|c|c|c|c|c|c|}
\hline \multirow[b]{2}{*}{ Region - } & \multicolumn{2}{|c|}{ Corn } & \multirow[b]{2}{*}{ Soybeans } & \multirow[b]{2}{*}{ Wheat } & \multirow[b]{2}{*}{ Hay } & \multirow[b]{2}{*}{ Cotton } & \multicolumn{2}{|c|}{ Sorghum } \\
\hline & Grain & Silage & & & & & Grain & Silage \\
\hline 1 & 2.17 & 13.72 & 0.65 & 1.03 & 2.01 & 0.16 & 1.57 & 11.31 \\
\hline 2 & 1.48 & 12.06 & 0.62 & 0.72 & 1.94 & 0.22 & 1.17 & 7.72 \\
\hline 3 & 2.15 & 10.98 & 0.70 & 1.02 & 2.26 & 0.18 & 1.44 & 10.39 \\
\hline 4 & 1.76 & 9.53 & 0.59 & 0.87 & 2.55 & -- & -- & - \\
\hline 5 & 1.70 & 6.28 & 0.60 & 0.74 & 1.41 & -- & 1.05 & 8.38 \\
\hline 6 & 2.56 & 13.00 & 0.75 & 0.56 & 2.09 & 0.13 & 1.45 & 12.18 \\
\hline 7 & 2.70 & 17.78 & -- & 0.83 & 2.18 & 0.25 & 0.97 & 9.22 \\
\hline 8 & 2.87 & 18.67 & - & 1.29 & 3.69 & 0.52 & 2.16 & 16.10 \\
\hline
\end{tabular}

Source: U.S. Department of Agriculture 1976. 
TABLE 2.7. Geographic Distribution of Fuel Use for Eight Major Commodities and Eight Regions in Billions Btu's, 1974

\begin{tabular}{|c|c|c|c|c|c|c|c|c|c|c|}
\hline & 1 & 2 & 3 & 4 & 5 & 6 & 7 & 8 & Totals & Percent \\
\hline \multicolumn{11}{|l|}{ CORN } \\
\hline $\begin{array}{l}\text { Gasol ine } \\
\text { Diesel } \\
\text { LPG } \\
\text { Nat. Gas } \\
\text { Elect. } \\
\text { Other }\end{array}$ & $\begin{array}{r}10334 \\
11823 \\
2205 \\
1072 \\
229 \\
750\end{array}$ & $\begin{array}{r}3967 \\
5219 \\
1134 \\
462 \\
119 \\
375\end{array}$ & $\begin{array}{r}7838 \\
25511 \\
30528 \\
1771 \\
1464 \\
423\end{array}$ & $\begin{array}{r}17144 \\
11316 \\
7307 \\
129 \\
491 \\
31\end{array}$ & $\begin{array}{r}10973 \\
26778 \\
15255 \\
18620 \\
3115 \\
2\end{array}$ & $\begin{array}{r}1232 \\
1603 \\
557 \\
6679 \\
481 \\
0\end{array}$ & $\begin{array}{r}1300 \\
2494 \\
359 \\
2691 \\
391 \\
0\end{array}$ & $\begin{array}{r}492 \\
1269 \\
21 \\
233 \\
1249 \\
0\end{array}$ & $\begin{array}{r}53280 \\
87013 \\
57362 \\
31657 \\
8039 \\
1581\end{array}$ & $\begin{array}{r}7.2 \\
11.7 \\
7.7 \\
4.3 \\
1.1 \\
0.2\end{array}$ \\
\hline Subtotal & 26413 & 11276 & 68535 & 36414 & 74743 & 10552 & 7735 & 3264 & 238932 & 32.3 \\
\hline \multicolumn{11}{|l|}{ SOYBE.ANS } \\
\hline $\begin{array}{l}\text { Gasoline } \\
\text { Diesel } \\
\text { LPG } \\
\text { Nat. Gas } \\
\text { Elect. } \\
\text { Other }\end{array}$ & $\begin{array}{r}4075 \\
6556 \\
269 \\
15 \\
99 \\
0\end{array}$ & $\begin{array}{r}10357 \\
13699 \\
1084 \\
431 \\
246 \\
0\end{array}$ & $\begin{array}{r}26909 \\
21404 \\
1630 \\
269 \\
604 \\
0\end{array}$ & $\begin{array}{r}4669 \\
3777 \\
259 \\
38 \\
102 \\
0\end{array}$ & $\begin{array}{r}2012 \\
2012 \\
305 \\
297 \\
99 \\
0\end{array}$ & $\begin{array}{r}394 \\
459 \\
69 \\
1052 \\
75 \\
0\end{array}$ & $\begin{array}{l}-- \\
-- \\
\therefore- \\
--\end{array}$ & $\begin{array}{l}- \\
- \\
-- \\
-- \\
-\end{array}$ & $\begin{array}{l}48416 \\
47997 \\
3616 \\
2102 \\
1225 \\
0\end{array}$ & $\begin{array}{l}5.5 \\
6.5 \\
0.5 \\
0.3 \\
0.2 \\
0\end{array}$ \\
\hline $\begin{array}{l}\text { Subtotal } \\
\text { WHEAT }\end{array}$ & 11014 & 25817 & 50816 & 8845 & 4815 & 2049 & - & - & 103356 & 14.0 \\
\hline $\begin{array}{l}\text { Gasoline } \\
\text { Oiesel } \\
\text { LPG } \\
\text { Nat. Gas } \\
\text { Elect. } \\
\text { Other }\end{array}$ & $\begin{array}{r}1833 \\
1750 \\
77 \\
0 \\
41 \\
0\end{array}$ & $\begin{array}{r}717 \\
1071 \\
37 \\
0 \\
20 \\
0\end{array}$ & $\begin{array}{r}4646 \\
945 \\
558 \\
1 \\
109 \\
0\end{array}$ & $\begin{array}{r}3103 \\
1550 \\
283 \\
0 \\
68 \\
0\end{array}$ & $\begin{array}{r}21940 \\
16063 \\
892 \\
1459 \\
549 \\
0\end{array}$ & $\begin{array}{r}8612 \\
2702 \\
1104 \\
10228 \\
921 \\
0\end{array}$ & $\begin{array}{r}6970 \\
4799 \\
539 \\
1441 \\
1310 \\
0\end{array}$ & $\begin{array}{r}3195 \\
2618 \\
182 \\
2052 \\
2467 \\
0\end{array}$ & $\begin{array}{r}51021 \\
37498 \\
3692 \\
15181 \\
5485 \\
0\end{array}$ & $\begin{array}{l}6.9 \\
5.1 \\
0.5 \\
2.0 \\
0.7 \\
0\end{array}$ \\
\hline $\begin{array}{l}\text { Subtotal } \\
\text { HAY }\end{array}$ & \multicolumn{9}{|c|}{ HAY } & 15.2 \\
\hline $\begin{array}{l}\text { Gasoline } \\
\text { Diesel } \\
\text { LPG } \\
\text { Nat. Gas } \\
\text { Elect. } \\
\text { Other }\end{array}$ & $\begin{array}{r}10251 \\
513 \\
1551 \\
640 \\
194 \\
0\end{array}$ & $\begin{array}{r}1485 \\
7 \\
240 \\
152 \\
58 \\
0\end{array}$ & $\begin{array}{r}14465 \\
536 \\
2005 \\
668 \\
181 \\
0\end{array}$ & $\begin{array}{r}18756 \\
1514 \\
2237 \\
1067 \\
201 \\
0\end{array}$ & $\begin{array}{r}5713 \\
11448 \\
2091 \\
11129 \\
1068 \\
0\end{array}$ & $\begin{array}{r}3580 \\
745 \\
673 \\
2864 \\
242 \\
0\end{array}$ & $\begin{array}{r}4586 \\
4728 \\
.1097 \\
8755 \\
4722 \\
0\end{array}$ & $\begin{array}{r}2528 \\
789 \\
316 \\
5687 \\
13136 \\
0\end{array}$ & $\begin{array}{r}62484 \\
20230 \\
10215 \\
30962 \\
19802 \\
0\end{array}$ & $\begin{array}{l}8.4 \\
2.7 \\
1.4 \\
4.2 \\
2.7 \\
0\end{array}$ \\
\hline \multicolumn{10}{|l|}{ COTTON } & 19.4 \\
\hline $\begin{array}{l}\text { Gasoline } \\
\text { Diese1 } \\
\text { LPG } \\
\text { Nat. Gas } \\
\text { Other }\end{array}$ & $\begin{array}{r}926 \\
1155 \\
76 \\
0 \\
0\end{array}$ & $\begin{array}{r}5357 \\
13919 \\
1135 \\
73 \\
0\end{array}$ & $\begin{array}{r}336 \\
617 \\
23 \\
0 \\
0\end{array}$ & $\begin{array}{l}-- \\
-- \\
-- \\
--\end{array}$ & $\begin{array}{l}- \\
- \\
- \\
--\end{array}$ & $\begin{array}{r}3758 \\
7702 \\
1184 \\
13581 \\
0\end{array}$ & $\begin{array}{r}298 \\
613 \\
257 \\
2474 \\
0\end{array}$ & $\begin{array}{r}2295 \\
4381 \\
0 \\
5589 \\
0\end{array}$ & $\begin{array}{r}12969 \\
28387 \\
2675 \\
21717 \\
0\end{array}$ & $\begin{array}{l}1.7 \\
3.3 \\
0.4 \\
2.9 \\
0\end{array}$ \\
\hline $\begin{array}{l}\text { Subtotal } \\
\text { SORGHUM }\end{array}$ & 2171 & 20672 & 982 & -- & \multicolumn{5}{|c|}{ SORGHUM } & 9.8 \\
\hline $\begin{array}{l}\text { Gasoline } \\
\text { Diesel } \\
\text { LPG } \\
\text { Nat. Gas } \\
\text { Elect. } \\
\text { Otner }\end{array}$ & $\begin{array}{r}166 \\
313 \\
10 \\
9 \\
3 \\
7\end{array}$ & $\begin{array}{r}324 \\
496 \\
38 \\
53 \\
7 \\
3\end{array}$ & $\begin{array}{r}688 \\
417 \\
194 \\
38 \\
20 \\
3\end{array}$ & $\begin{array}{l}-- \\
-- \\
-- \\
-- \\
--\end{array}$ & $\begin{array}{c}--3968 \\
5297 \\
1363 \\
4023 \\
334 \\
0.3\end{array}$ & $\begin{array}{r}87098 \\
8327 \\
2067 \\
23173 \\
1713 \\
0\end{array}$ & $\begin{array}{r}453 \\
513 \\
276 \\
2563 \\
273 \\
0\end{array}$ & $\begin{array}{r}230 \\
332 \\
25 \\
1960 \\
1211 \\
0\end{array}$ & $\begin{array}{r}12927 \\
15795 \\
3987 \\
31829 \\
3561 \\
13\end{array}$ & $\begin{array}{l}1.7 \\
2.1 \\
0.5 \\
4.3 \\
0.5 \\
0\end{array}$ \\
\hline Subtotal & 508 & 946 & $i 360$ & -- & 14985.00 & 42372 & 4183 & 3758 & 58112 & 9.2 \\
\hline TOTALS & 56961 & 55542 & 156099 & 74038 & 167895 & 179925 & 54729 & 57690 & 742879 & $i 00.00$ \\
\hline PERCENT & 7.7 & 7.5 & 21.0 & 10.0 & 22.6 & 16.7 & 7.4 & 7.8 & 100.00 & \\
\hline
\end{tabular}

NOTE: This table does not include energy invested in pesticides or fertilizer.

Source: U.S. Department of Agriculture 1976 
The various farming operations common to general crop production were 1 isted in Energy and U.S. Agriculture: 1974 and 1978 (U.S. Department of Agriculture 19). These farm functions are not crop specific and they do not distinguish irrigated from nonirrigated cultural practice. However, the list is considered reasonably representative of all agricultural crop production.

Energy use by farm function appears in Table 2.8. Examination of this table reveals that irrigation and fertilizer are the two largest energy consumers, totaling about 50\% of the energy input to total crop production. Fertilizers account for one-third of the energy used in agriculture. On a regional basis, regions 3 and 5 use the most energy, accounting for 23.2 and 15.4 percent of the energy used for crop production. Region 3 uses twice as much energy in the form of fertilizer than any other region. Regions 5 and 1 rank second and third, respectively.

Fertilizer not only requires the largest share of farm energy, it is most likely the most complex because fertilizer use is a function of the estimated yields from alternative levels of use. Based on these estimated yields, the decision to use a given quantity of fertilizer is predicated on the cost of the fertilizer and the expected price of the commodity. Thus, the relative amount of energy embodied in fertilizer among regions could be expected to shift as the relative prices of commodities change.

\subsection{ENERGY CONSUMPTION IN LIVESTOCK PRODUCTION}

This section describes energy consumption for livestock production. Regional energy patterns are described by operation and livestock type, followed by descriptions of energy use for each major livestock type.

\subsubsection{Regional Energy Consumption By Operation and Livestock Type}

The distribution of energy use on a regional basis is shown by region in Table 2.9. The leading regions of energy use are regions 1,2 and 3 respectively, accounting for $17.4,14.3$ and 14.6 percent of the energy used in livestock production. However, the energy consumption by 
TABLE 2.8. Energy Input by Farm Function and Region for Crop Production, 1978 (Billion Btu's)

\begin{tabular}{|c|c|c|c|c|c|c|c|c|c|}
\hline \multicolumn{8}{|c|}{ Region } & \multirow[b]{2}{*}{ Total } & \multirow[b]{2}{*}{ Percent } \\
\hline 1 & $\underline{2}$ & 3 & $\underline{4}$ & 5 & $\underline{6}$ & 7 & $\underline{8}$ & & \\
\hline 13865 & 21183 & 36081 & 16229 & 25995 & 28204 & 12261 & 19570 & 173388 & 9.5 \\
\hline 4233 & 5323 & 13375 & 6031 & 6701 & 6719 & 2659 & 2475 & 47516 & 2.6 \\
\hline 4755 & 12656 & 13485 & 4340 & 4165 & 4699 & 1513 & 4384 & 49997 & 2.8 \\
\hline 21781 & 18533 & 32766 & 21182 & 26707 & 10543 & 10886 & 11727 & 154125 & 8.5 \\
\hline 11797 & 11822 & 41762 & 14439 & 24753 & 10084 & 6949 & 8161 & 129767 & 7.1 \\
\hline 2983 & 4161 & 1776 & 973 & 979 & 261 & 1070 & 670 & 12873 & 0.7 \\
\hline 2881 & 4469 & 1713 & 1613 & 985 & 1254 & 1027 & 2955 & 16897 & 0.9 \\
\hline 10021 & 5787 & 16230 & 8644 & 12842 & 4668 & 5059 & 4482 & 67733 & 3.7 \\
\hline 8802 & 4587 & 13108 & 7253 & 11602 & 4219 & 4718 & 6478 & 60767 & 3.3 \\
\hline 186 & 59 & 786 & 241 & 456 & 21 & 105 & 49 & 1903 & 0.1 \\
\hline 7 & 2 & 46 & 19 & 29 & 2 & 8 & 3 & 116 & 0 \\
\hline 21339 & 6984 & 29635 & 7023 & 5802 & 346 & 244 & 109 & 71482 & 3.9 \\
\hline 1571 & 12007 & 936 & 1124 & 51600 & 85093 & 41572 & 57244 & 252147 & 13.9 \\
\hline 1825 & 21182 & 151 & 1152 & -- & 2005 & 125 & 13389 & 39829 & 2.2 \\
\hline 82206 & 63161 & 205322 & 70689 & 95905 & 53771 & 30374 & 50438 & 651876 & 35.9 \\
\hline 8025 & 19665 & 13171 & 5631 & 5107 & 7826 & 1750 & 7027 & $68 ? .02$ & 3.8 \\
\hline 561 & 580 & 1452 & 640 & 1228 & 608 & 413 & 320 & 5802 & 0.3 \\
\hline 1835 & 1697 & 198 & 603 & 5816 & 1979 & 560 & 1454 & 14142 & 0.8 \\
\hline 198673 & 214858 & 422003 & 167826 & 280672 & 222302 & 121293 & 190935 & 1818562 & 100 \\
\hline
\end{tabular}

Percent

$\begin{array}{llllllll}10.9 & 11.8 & 23.2 & 9.2 & 15.4 & 12.2 & 6.7 & 10.5\end{array}$

100

Source: U.S. Department of Agriculture 1980 
TABLE 2.9. Energy Input by Livestock Type and Region, 1974 (Billion Btu's)

$\underline{\text { Livestock }}$

Beef-Cows and Calves

Beef-Feedlot

Milk Cows

Hogs

Chicken-Layers

Chicken-Pullets

Broilers

Turkeys

Misc. Poultry

Total

Percent
Sheep and Lambs

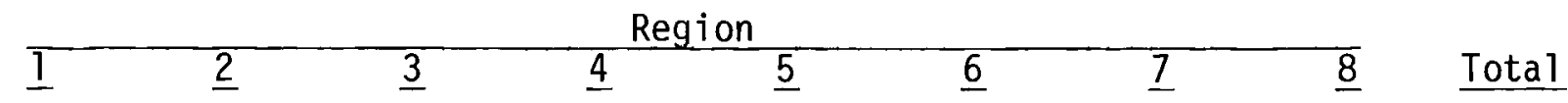

$\begin{array}{rrrrrrrrr}6652 & 7557 & 8562 & 1976 & 16553 & 13689 & 7591 & 7161 & 69741 \\ 840 & 167 & 2749 & 2405 & 3109 & 2278 & 1780 & 3055 & 16383 \\ 13391 & 4271 & 4296 & 13046 & 2878 & 2571 & 2013 & 7827 & 50293 \\ 3544 & 2891 & 11665 & 4950 & 1000 & 672 & 122 & 128 & 24972 \\ 1376 & 1437 & 425 & 363 & 168 & 241 & 119 & 1196 & 5325 \\ 1516 & 1653 & 538 & 511 & 229 & 308 & 151 & 853 & 5759 \\ 6359 & 10509 & 216 & 203 & 20 & 1587 & -- & 958 & 19852 \\ 1020 & 422 & 717 & 2155 & 159 & 541 & 425 & 1221 & 6660 \\ 288 & 19 & 370 & 287 & 457 & 407 & 984 & 513 & 3325 \\ 422 & 65 & 125 & 79 & 9 & 32 & 4 & 101 & 837 \\ 35418 & 28991 & 29663 & 25975 & 24582 & 22326 & 13189 & 22998 & 203142 \\ 17.4 & 14.3 & 14.6 & 12.8 & 12.1 & 11.0 & 6.5 & 11.3 & 100\end{array}$

Source: U.S. Department of Agriculture 1976. 
region is relatively evenly distributed with region 7 having the lowest consumption at 6.5 percent. The highest energy need is for beef-cows and calves in region 5, accounting for 16,553 billion Btu's. Region 6 also has a high energy use for beef-cows and calves. Regions 1 and 4 have high energy use for dairy farms (milk cows), using 13,391 and 13,046 Btu's respectively. Region 3 has the highest energy use for hog production at 11,665 Btu's. Region 2 has a high energy use for broiler production, which uses 10,509 Btu's.

Regional energy use is shown by operation in Table 2.10. Feed handling in regions $3\left(13,642 \mathrm{Btu}{ }^{\prime} \mathrm{s}\right)$ and 5 (19,813 Btu's), brooding in region $2(10,107 \mathrm{Btu}$ 's), and farm vehicles in region $3(12,933 \mathrm{Btu}$ 's) have the highest energy needs.

\subsubsection{Energy in Beef Cattle Production}

Energy requirements in beef cattle production have been reported by Lipper, Anschultz, and Welker (1976). Their findings are based on a survey of 14 Kansas feedlots over a three-year period. A total of 30 feedlot-years of energy use data was compiled.

Total energy use was broken down to reflect energy requirements for specific operations associated with large-scale cattle feeding. Energies reported in Table 2.11 are in Btu's per 100 lbs of beef produced. Given also are the percentage of total energy required for each operation and the percentages of major energy forms used in each process.

Feed processing energy in the form of natural gas (84\%) and electricity (15\%) accounts for $57 \%$ of the total energy required in beef production. Feed processing includes preparing feed grains, handling roughage feeds (corn and milo stovers), adding mineral supplements, and mixing. Feed grain preparation to improve the digestibility of the grain requires a major portion of the total feed processing energy. Natural gas provides energy for cooking and electricity for rolling or flaking the grain.

\subsubsection{Energy in Dairy Production}

Energy requirements in dairy production have been reported by Anschultz and Lipper (1975). They estimate that in 1973 Kansas dairies 
TABLE 2.10. Energy Input by Operation and Region for Livestock Production, 1978
(Billion Btu's)

\begin{tabular}{|c|c|c|c|c|c|c|c|c|c|}
\hline \multirow[b]{2}{*}{ Operation } & \multicolumn{8}{|c|}{ Region } & \multirow{2}{*}{$-10 t+1$} \\
\hline & 1 & $\underline{2}$ & $\underline{3}$ & $\underline{4}$ & $\underline{5}$ & $\underline{6}$ & $\underline{7}$ & $\underline{8}$ & \\
\hline Lighting & 1031 & 889 & 798 & 635 & 664 & 743 & 378 & 691 & $583 \%$ \\
\hline Feed Handling & 6063 & 3612 & 13642 & 3340 & 19813 & 6214 & 6478 & 5646 & 64808 \\
\hline Waste Disp. (Vehs) & 4512 & 2195 & 7172 & 3237 & 1080 & 1334 & 916 & 2899 & $233+5$ \\
\hline Waste Disp. (Mach) & 334 & 441 & 153 & 129 & 31 & 147 & 45 & 306 & 128 \\
\hline Water Supply & 781 & 383 & 2507 & 1012 & 109 & 98 & 115 & 164 & 510.9 \\
\hline Livestock Handling & 89 & 86 & 50 & 27 & 974 & 741 & 335 & 245 & 2047 \\
\hline Space Heating & 324 & 169 & 3976 & 957 & 62 & 36 & 80 & 153 & $\because \cdots 7$ \\
\hline Ventilation & 1579 & 862 & 2375 & 1220 & 91 & 167 & 86 & 451 & $\therefore \quad 2$ \\
\hline Water Heating & 2487 & 793 & 1303 & 2403 & 506 & 512 & 384 & 1349 & 9727 \\
\hline Milking & 686 & 230 & 354 & 647 & 139 & 140 & 111 & 404 & $\therefore: 1$ \\
\hline Milk Cooling & 1225 & 333 & 584 & 1197 & 215 & 191 & 163 & 543 & $\therefore \therefore$ \\
\hline Egg Handling & 30 & 20 & 12 & 5 & .1 & 1 & 2 & 33 & 104 \\
\hline Brooding & 7326 & 10107 & 1855 & 2416 & 240 & 1864 & 540 & 2331 & $\cdots \ldots+\cdots$ \\
\hline Farm Vehicles & 3422 & 3123 & 12933 & 2693 & 1937 & 6182 & 3458 & 2745 & 36.493 \\
\hline Farm Auto-Lvstk & 1912 & 616 & 1901 & 1374 & 1062 & 380 & 576 & 786 & $\therefore \cdots$ \\
\hline Other & 4583 & 2282 & 1401 & 2887 & 883 & 361 & 686 & 1509 & 14592 \\
\hline Total & 36384 & 26141 & 51016 & 24179 & 27807 & 19111 & 14353 & 22255 & $2: 04$ \\
\hline Percent & 16.4 & 11.8 & 23.1 & 10.9 & 12.6 & 8.6 & 6.5 & 10. & \\
\hline
\end{tabular}

Source: U.S. Department of Agriculture 1980. 
TABLE 2.11. Beef Production Energy Requirements

\begin{tabular}{lc}
$\begin{array}{l}\text { Operation } \\
\text { Feed } \\
\text { Processing }\end{array}$ & $\begin{array}{c}\% \text { of Total } \\
\text { Energy }\end{array}$ \\
\cline { 2 - 2 } $\begin{array}{l}\text { Feed } \\
\text { Handling }\end{array}$ & $57 \%$ \\
Watering & $16 \%$ \\
Lighting & $2.5 \%$ \\
Waste Removal & $1.3 \%$ \\
Administration & $4 \%$ \\
& \\
Branding \& Thawing & $5.5 \%$ \\
Space Heating & $1 \%$ \\
Miscellaneous & $1.5 \%$
\end{tabular}

Energy Required (Btu/100 1b Beef) Major Energy Forms $\begin{array}{ll} & \\ \text { Natural Gas } & 84 \% \\ \text { Electrical } & 15 \%\end{array}$

107,000

31,000

4,810

Gasoline
Diesel

Natural Gas $47 \%$

Electrical $\quad 45 \%$

Gasoline $\quad 8 \%$

$2,510 \quad$ Electrical $\quad 100 \%$

7,680

Natural Gas $12 \%$

Gasoline $\quad 34 \%$

Diese $1 \quad 51 \%$

Natural Gas $29 \%$

Gasoline $\quad 63 \%$

Electrical $\quad 8 \%$

Natural Gas $84 \%$

Electrical $\quad 12 \%$

Natural Gas $1.5 \%$

Natural Gas $70 \%$

Gasoline $\quad 14 \%$

Diese 1

Total $=189,190 \mathrm{Btu} / 100 \mathrm{lb}$ Beef

Source: Lipper, et a1, 1976. 
used the equivalent of 63.2 million KWh of energy to produce 1,505 million pounds of milk.

A Ereakdown of total energy use in dairies has been reported by Frank (1977). Table 2.12 gives the percentages of total energy use in Btu's per 100-1bs of milk produced and the typical energy sources for each major operation.

Waste removal makes up $26 \%$ of the total energy use in dairy production and typically includes disposal of waste water from milking operations, collection of manure, and field application of the liquid manure slurry.

\subsubsection{Energy in Poultry (Broi Ter) Production}

Energy requirements in broiler production have been reported by Baughman and Parkhurst (1976). Summer and winter trials were conducted comparing a conventional curtainwali broiler house with no mechanical ventilation to a fuliy enclosed, insulated broiler house with mechanical ventilation.

Total energy requirements were broken down to reflect requirements and typical energy sources for major operations in broiler production. Energy data reported in Table 2.13 are the average of the summer and winter trails for the conventional broiler house. Units are Btu's per pound of bird produced.

Feed production and processing accounts for more than $80 \%$ of the total energy used in broiler production. Note that the major portion of this energy figure is required in feed production. Feed production energies have not been included in the energy figures reported here for beef, dairy, and swine production.

\subsubsection{Energy in Swine Production}

Estimated energy requirements in swine production have been reported by Smith, Miranowski, and Vetter (1976) and are given in Table 2.14 in Btu's per 100-1bs of pork produced. The proposed swine operation has a capacity 
TABLE 2.12. Dairy Production Energy Requirements

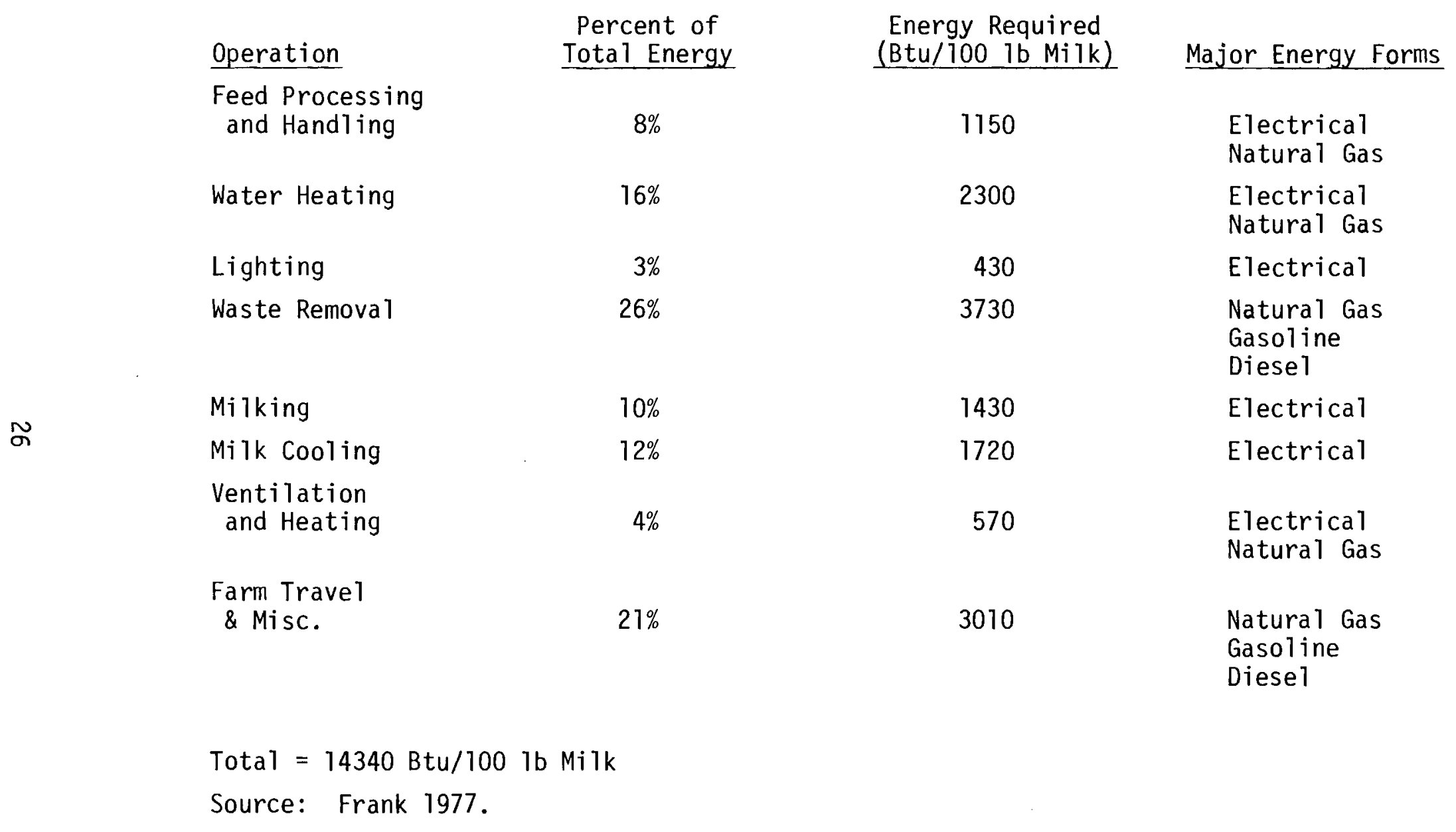


TABLE 2.13. Energy Requirements for Poultry Production

\begin{tabular}{|c|c|c|c|}
\hline Operation & $\begin{array}{l}\text { Percent of } \\
\text { Total Energy }\end{array}$ & $\begin{array}{l}\text { Energy Required } \\
\text { (Btu/lb of Bird) }\end{array}$ & Major Energy Forms \\
\hline $\begin{array}{l}\text { Brooding } \\
\text { (Space Heating) }\end{array}$ & $16 \%$ & 2300 & $\begin{array}{l}\text { LPG (gr) } \\
\text { Natural Gas }\end{array}$ \\
\hline Lighting & $2 \%$ & 250 & Electrical \\
\hline $\begin{array}{l}\text { Feed Production } \\
\text { and Processing }\end{array}$ & $82 \%$ & 12040 & $\begin{array}{l}\text { LPG } \\
\text { Electrica } 1 \\
\text { Gasoline } \\
\text { Diese1 }\end{array}$ \\
\hline \multicolumn{4}{|c|}{ Total $=14590 \mathrm{Btu} / 1 \mathrm{~b}$ of bird $(\mathrm{a})$} \\
\hline \multicolumn{4}{|c|}{$\begin{array}{l}\text { (a) This total includes feed production energy and should not be } \\
\text { compared with other total energy figures reported for beef, dairy, } \\
\text { and swine production. }\end{array}$} \\
\hline
\end{tabular}

TABLE 2.14. Energy Requirements for Swine Production

\begin{tabular}{|c|c|c|c|}
\hline Operation & $\begin{array}{l}\text { Percent of } \\
\text { Total Energy }\end{array}$ & $\begin{array}{l}\text { Energy Required } \\
\text { (Btu/ } 100 \text { lb of Pork) }\end{array}$ & Major Energy Forms \\
\hline $\begin{array}{l}\text { Feed Preparation } \\
\text { and Handling }\end{array}$ & $2 \%$ & 2800 & $\begin{array}{l}\text { Electrical } \\
\text { Gasoline } \\
\text { Diesel }\end{array}$ \\
\hline Space Heating & $67 \%$ & 97000 & $\begin{array}{l}\text { LPG } \\
\text { Natural Gas } \\
\text { Electrical }\end{array}$ \\
\hline Ventilation & $31 \%$ & 44200 & Electrical \\
\hline
\end{tabular}


of 50 sows plus an average of 12.75 pigs per sow per year. Pigs were fed to 220 pounds with high-moisture corn to minimize energy use.

Power requirements for various operations were obtained from equipment suppliers where information was available. Other power requirements were taken from the Structurers and Environment Handbook (Midwest Plan Service 1975).

Total energy requirements were broken down to reflect energy requirements of specific operations. Energy requirements were quantified for the areas of space heating, ventilation, and feed processing and handling. No attempt was made to quantify energy requirements for operations such as waste removal, watering, and lighting.

Pigs have a rather limited ability to regulate their body heat through changes in their metabolism. For this reason, maximum gains are achieved in a relatively narrow temperature range $\left(60\right.$ to $\left.70^{\circ} \mathrm{F}\right)$. As reported here, space heating requires $67 \%$ of the total energy requirement.

\subsection{CONCLUSION}

An analysis of energy intensity by commodity shows that corn and hay production are the biggest energy users. The Midwest (Region 3) and the states that bracket the 100 meridian (Regions 5 and 6) are the regions with the greatest need for an Energy-Integrated Farm System Program.

An analysis of the geographic distributions of fuel use shows that if the Energy-Integrated Farm Systems Program is to contribute to the substitution of renewable farm resources for imported oil, the program should focus on corn in the Northeast quarter of the country: Kansas to Maine (Regions 1, 3, 4, and 5).

An analysis of the functional uses of energy in the farming operation shows that the largest share of energy is mechanical mobile. The Midwest (Region 3) and the states that bracket the 100 meridian (Regions 5 and 6) consume over $70 \%$ of the mechanical energy used to power American agriculture. The Midwest (Region 3 ) uses the most chemical energy of any region. 
When the nation is differentiated based on the recognition of the farm-energy market, it is concluded that over $50 \%$ of the program should focus on the development of mechanical (both mobile and stationary) energy from farm sources. Forty percent of the program should focus on replacement chemical energy with energy generated from the farm. Over $50 \%$ of the program resources should concentrate on technology applicable to the Central United States from Ohio on the east to North Dakota and south to Texas (Region 3,5 and 6). 


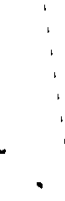


CHAPTER 3

\section{AN ANALYSIS OF AVAILABILITY OF RENEWABLE RESOURCES}

Energy currently enters through the farm gate in fuel and fertilizer trucks. It enters through power 1 ines, and in the form of other inputs bought in town. Other energy sources are also available: the sun, the wind, stream flow and the earth's heat energy. The purpose of the analysis presented in this chapter is to estimate the availability of renewable resources for farmers to attain a satisfactory degree of independence from their current sources of energy.

Potential resources available for production of alternative energy are site-dependent. Detailed county-by-county and farm-by-farm inventories of these resources are required for a precise estimate of the potential. However, the availability of the renewable energy resource base can be assessed on a broad scale. Time dependent resources are measured during the farming season, which is defined as the period six weeks before to six weeks after the frost-free days. The mean farming season is the average available value for the specific region. This chapter does not attempt to measure the practicality or the economics of renewable resources. Rather, it attempts to assess on a broad basis whether they are available.

\subsection{SOLAR INSOLATION}

Table 3.1 presents averages of solar energy received at several locations in the U.S. Lincoln, Nebraska, represents a crude average for solar insolation in the 48 contiguous United States. For the six "agricultural" months of April through September, solar energy availability in Lincoln would on the average be approximately $1800 \mathrm{Btu} / \mathrm{ft}^{2} /$ day, which is equivalent to $78 \times 10^{6}$ Btu/acre/day or $50.2 \times 10^{9} \mathrm{Btu} / \mathrm{mile} /$ day.

The 1.0786 billion acres of farms in the U.S. require about $2,480,202$ billion Btu's/yr (Tables 2.1 and 2.2) or about 2.3 million Btu/acre/yr. Since in an average day 78 million Btu's fall on a single acre, the solar energy available in about $3 \%$ of one day is equivalent to the energy requirements. If the sun shines 180 days a 1,000 acre farm would 
TABLE 3.1. Daily Averages of Solar Energy Received on a Horizontal Surface -- Monthly (a)

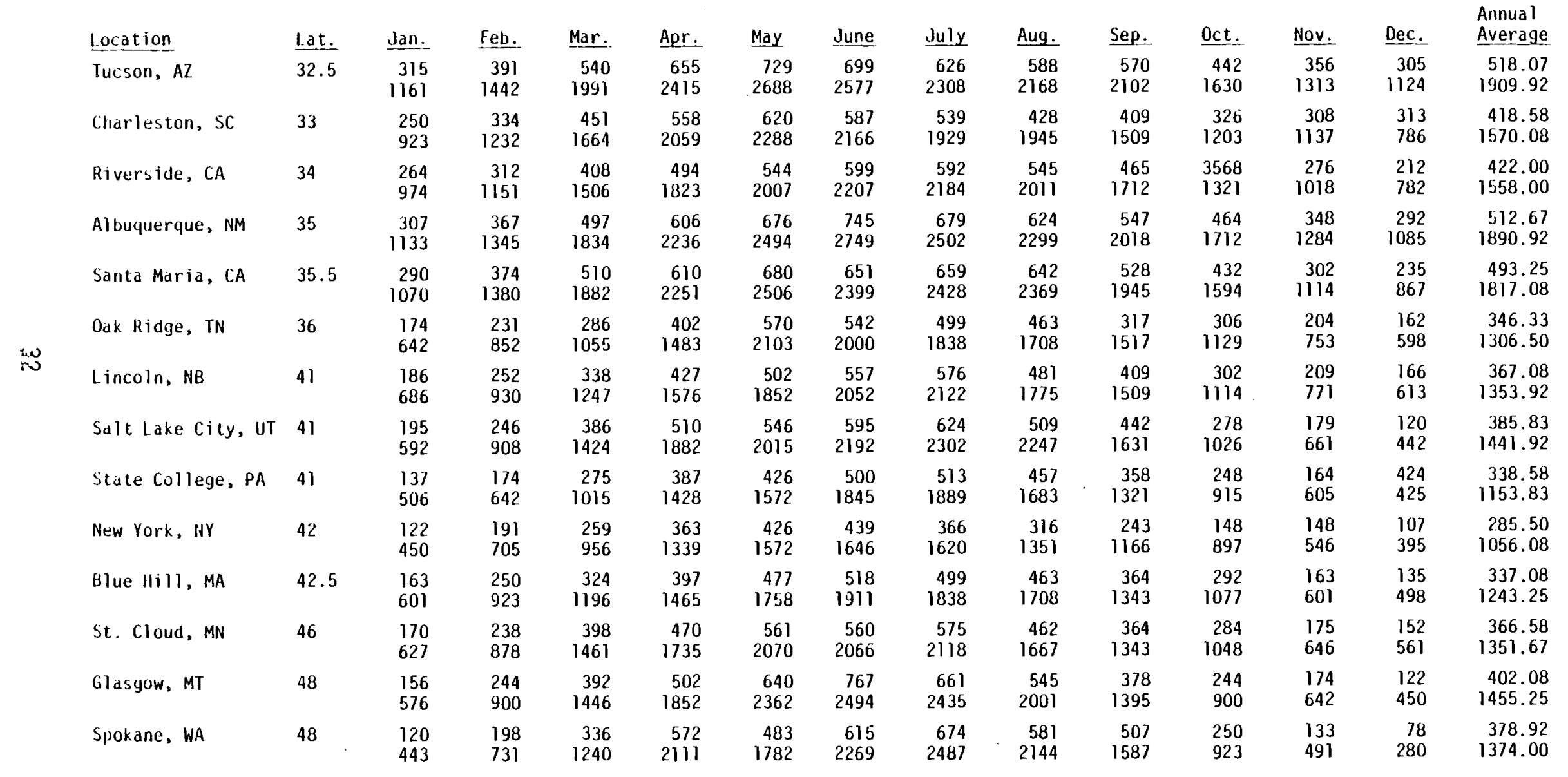

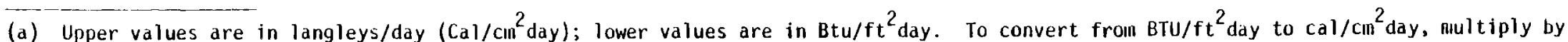
0.27125 .

Source: Meinel 1977 
require less than $2 / 10$ acre to supply the energy. Again, only gross energy availability is considered, not practicality or economics.

Any concern that the farm would be filled-up with collectors appears to be clearly groundless. A question that still might be asked is whether all the regions have enough solar energy to supply farm needs. The regions differ substantially in annual averages as Table 3.1. shows. That part of the energy needs relating to growing crops wi11, however, have less variation, as Table 3.2 shows.

At $1600 \mathrm{Btu} / \mathrm{ft}^{2} /$ day the northeast has a somewhat lower average for the growing season than the mountain west at $2200 \mathrm{Btu} / \mathrm{ft}^{2} /$ day. However, neither is more than $\pm 15 \%$ of the $1900 \mathrm{Btu} /$ day aggregate for the country as a whole. While the growing season in the north is shorter than in the south, the sun does shine in the north during the growing season, -it warms the soil and the long warm days correlate fairly well with the growing season. The figures in Table 3.2 resulted directly from Table 3.1 using the frost-free data from The National Atlas of the United States of America (1970) to define the number of months averaged. Much solar energy is available during the growing season all over the contiguous 48 states. Local values may vary a great deal from regional values. Specific siting, conversion technology and function or use will determine whether or not even a fraction of this can be achieved. Thus a key conclusion from looking at the amount of energy available in all regions during the growing season (see Table 3.2) is that there is plenty of sunshine available during the growing season most places where the sun shines enough to keep the ground warm enough to grow crops. The peak region varies no more than 15\% from the average in Table 3.2 .

\subsection{WIND POWER AVAILABILITY}

The average wind power availability of the United States is shown in Figure 3.1. Average annual wind power availability at $50 \mathrm{~m}$ above the ground surface varies from $100 \mathrm{~W} / \mathrm{m}^{2}$ to $500 \mathrm{~W} / \mathrm{m}^{2}$. Siting, timing, and conversion technology will combine to drastically reduce availability on a practical scale. 
TABLE 3.2. An Estimate of the Available Solar Energy During the Mean Farming Season, by Region

\begin{tabular}{c} 
Region \\
\hline 1 \\
2 \\
3 \\
4 \\
5 \\
6 \\
7 \\
8 \\
\hline AGGREGATE
\end{tabular}

\begin{tabular}{l} 
Geographic Area \\
\hline Northeast \\
Southeast \\
Midwest \\
Northcentral \\
Plains \\
Texas-Oklahoma \\
Mountain \\
Far West
\end{tabular}

\begin{tabular}{c} 
Btu/ft ${ }^{2} /$ Day \\
\hline 1600 \\
1900 \\
1700 \\
1800 \\
1900 \\
2000 \\
2200 \\
$\frac{2100}{1900}$
\end{tabular}




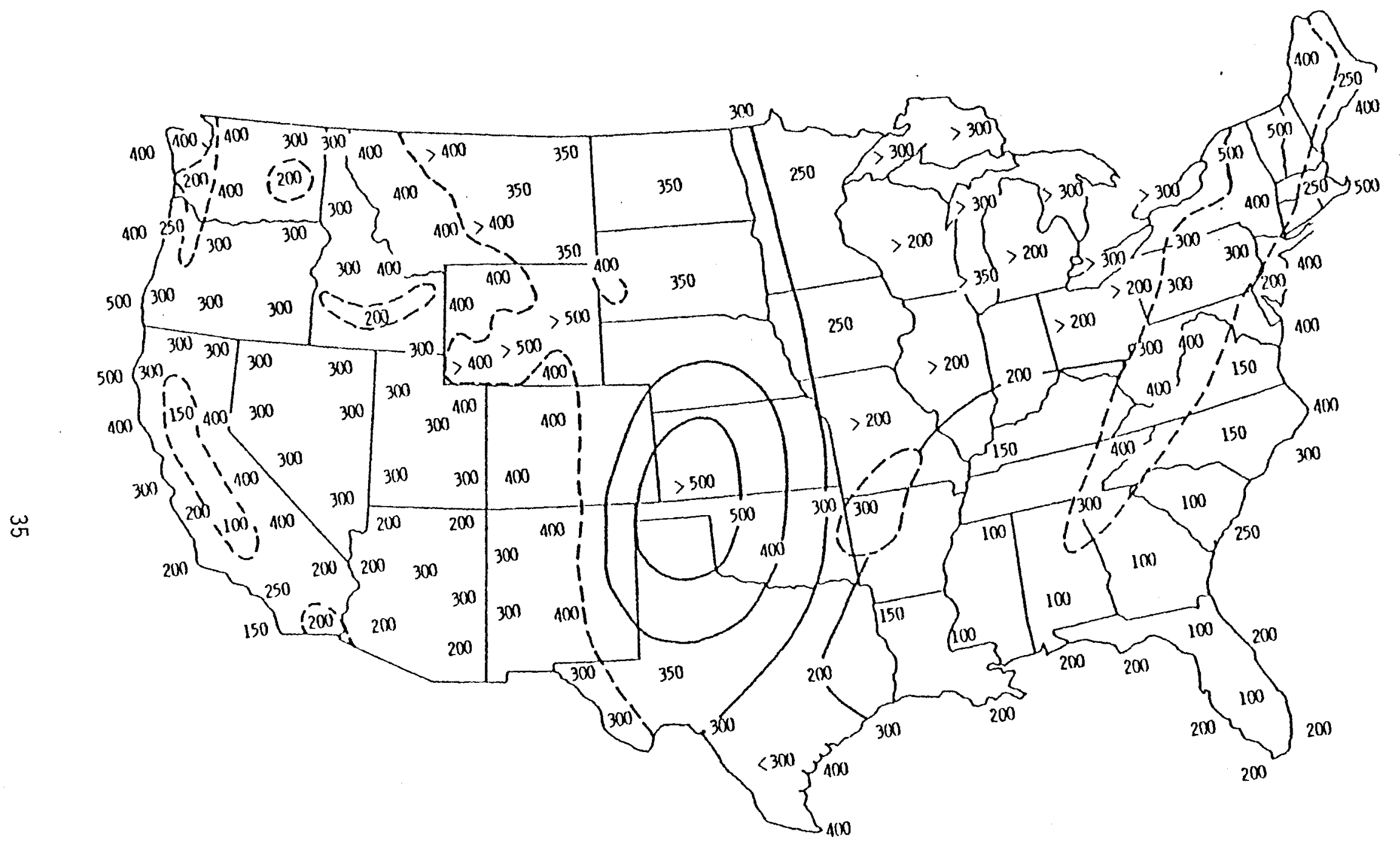

FIGURE 3.1. Annual Average Wind Power $\left(\mathrm{W} / \mathrm{m}^{2}\right)$ at $50 \mathrm{~m}$ (E11iott 1977). 
Overall wind availability for the farm use can be estimated by assuming:

- Five to ten 2.5 MW machines can be placed on a square mile of land.

- Large machines may give $25 \%$ of rated full power averaged over a year.

- Farms require 2.3 million Btu/acre/yr.

When these assumptions and five machines per square mile are used 12.5 $\mathrm{MW} / \mathrm{mile}$ of wind energy can be achieved. For 8,760 hours per year at $25 \%$ availability $9.343 \times 10^{10} \mathrm{Btu} / \mathrm{yr} / \mathrm{mile}^{2}$ would be available. At 640 acres to the square mile, $146 \mathrm{million} B$ tu/acre/yr is achieved, or more than 60 times the amount of energy required per year for crops per acre. For a 1,000 acre farm about 17 acres would be needed for wind machines to get the energy needed for a "typical farm"; possibly double use of the land could be achieved, but all uses may not be compatible as many factors exist which might change the outcome.

Several problems need to be considered when applying wind energy to farm needs. One problem is that the growing season is usually the poorest wind season of the year (summer wind power availability is shown in Figure 3.2). Another problem is that farms are frequently not located up on the hilltops where the best winds blow.

In Table 3.3 the expected wind power ( $\mathrm{W} / \mathrm{m}^{2}$ of vertical surface) is shown for the various regions for the four seasons. If $400 \mathrm{~W} / \mathrm{m}^{2}$ at 50 $\mathrm{m}$ is assumed to be the lower limit for economic application, Regions 1 through 4 and Region 7 would be largely excluded since only in unique locations (hilltops, etc.) does the flux exceed the value of $400 \mathrm{~W} / \mathrm{m}^{2}$. In the other three regions, the values are high enough to be seriously considered.

In the northwest region and regions 5 and 6 on $1 y$ 10\% of the land area has a suitable value (from detailed assessments in progress at PNL) of $400 \mathrm{~W} / \mathrm{m}^{2}$ at $50 \mathrm{~m}$ of height, or more. If the $10 \%$ rule applies for all the farms then Table 3.4 can be developed.

If the wind blows at $200 \mathrm{~W} / \mathrm{m}^{2}$ in the summer time, an average farm could get all its energy needs (ignoring energy form needed) by using 


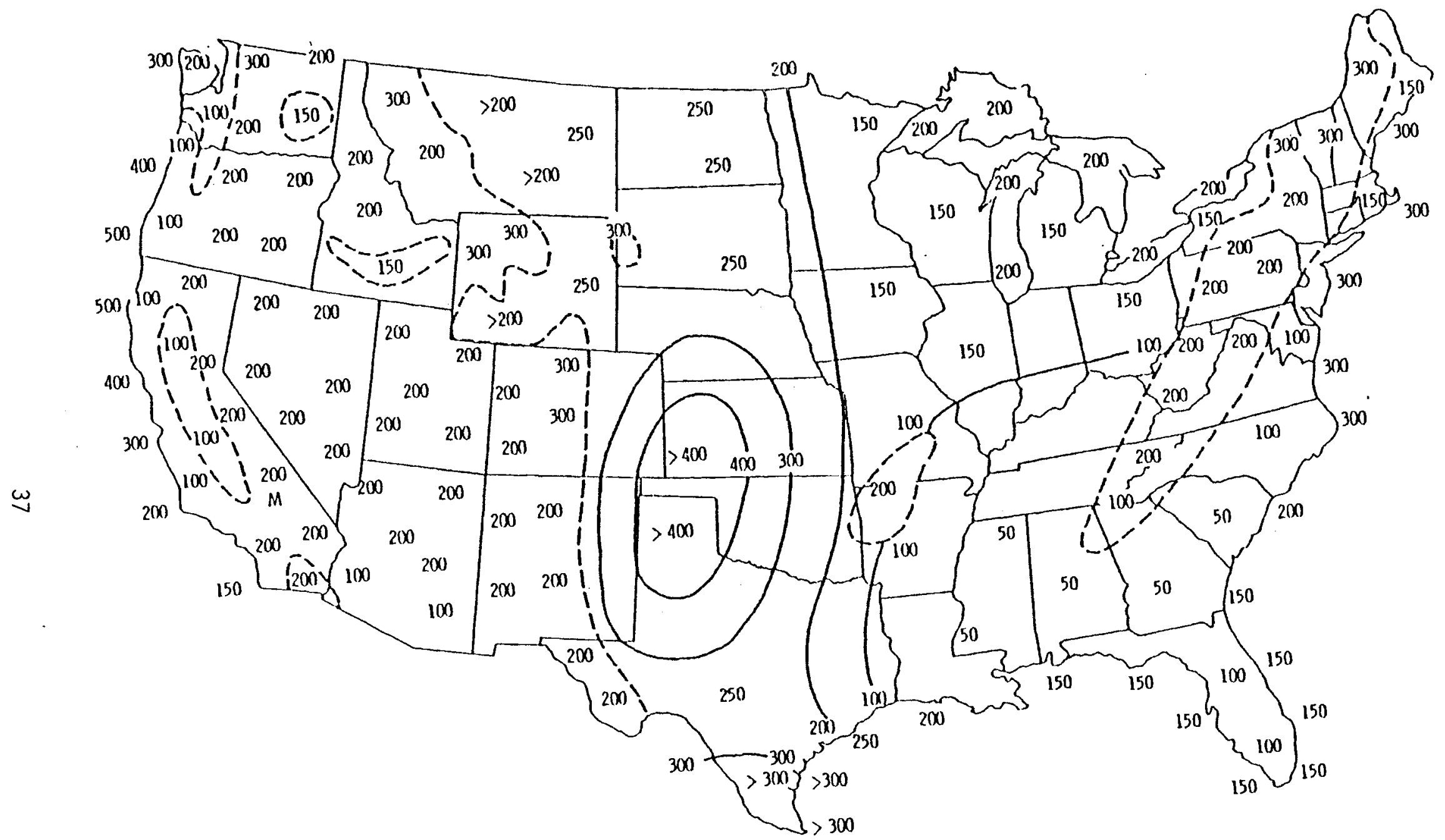

FIGURE 3.2. Summer - Average Wind Power $\left(W / \mathrm{m}^{2}\right)$ Estimated at $50 \mathrm{~m}$ Above Exposed Areas (Elliott 1977). Over mountainous regions, the estimates are lower limits expected for exposed mountain tops and ridges. 
Table 3.3. Expected Available Wind Power $\left(\mathrm{W} / \mathrm{m}^{2}\right)$ at Farm Elevations (50 m)

\begin{tabular}{|c|c|c|c|c|c|}
\hline Region & $\begin{array}{l}\text { Geographical } \\
\text { Area } \\
\end{array}$ & Winter & Spring & Summer & Fal1 \\
\hline 1 & Northeast & 150 to 400 & 150 to 400 & 50 to 200 & 100 to 250 \\
\hline 2 & Southeast & 150 to 250 & 150 to 300 & 50 to 100 & 50 to 200 \\
\hline 3 & Midwest & 150 to 400 & 200 to 450 & 100 to 200 & 100 to 300 \\
\hline 4 & Northcentral & 200 to 400 & 200 to 450 & 100 to 200 & 100 to 300 \\
\hline 5 & Plains & 300 to 600 & 350 to 700 & 150 to 500 & 250 to 500 \\
\hline 6 & Texas-0k1ahoma & 200 to 600 & 200 to 700 & 100 to 500 & 100 to 500 \\
\hline 7 & Mountain & 150 to 800 & 150 to 600 & 50 to 300 & 100 to 500 \\
\hline 8 & Far West & 150 to 600 & 150 to 600 & 50 to 700 & 50 to 400 \\
\hline
\end{tabular}

NOTE: For an estimate of available wind power at $10 \mathrm{~m}$ divide these numbers by 2 .

Source: Elliott, 1977.

TABLE 3.4. Percent of Farm Energy Available as Wind Energy

\begin{tabular}{ccc} 
Region & Geographical Area & Percent \\
\cline { 3 - 3 } 1 & Northeast & -- \\
2 & Southeast & -- \\
3 & Midwest & -- \\
4 & Northcentral & -- \\
5 & Plains & 10 \\
6 & Texas - 0klahoma & 10 \\
7 & Mountain & -- \\
8 & Far West & 10
\end{tabular}


wind, but half of the regions will have few sites with the needed wind flux intensity and of the others only about 10\% of the farms will have the needed wind flux intensity. Additional problems with matching the specific energy needs occur, but these will be covered in the following chapter.

One problem, which gives typical values of the wind energy available during the summer and which is not reflected in Table 3.3, is the high degree of variability of local sites for wind applications. Sometimes local variations are dramatic, making some excellent sites only a few hundred feed away from very poor areas. Applications need to be considered carefully to see that individual locations are chosen we11.

\subsection{ON-FARM STREAM FLOW AVAILABILITY}

The aggregate stream flow and head requirements $(Q \times H)$ equivalent to the annual energy demand by production agriculture can be described as follows:

Agricultural Energy Demand

The Equivalent Rate over 180 Days Giving,

$$
\begin{aligned}
& =2.48 \times 10^{15} \mathrm{Btu} \\
& =5.7 \times 10^{11} \mathrm{Btu} / \mathrm{hr} \\
P & =1.67 \times 10^{8} \mathrm{kWe} \\
Q \times H & =11.8 \mathrm{P} / \mathrm{e} \\
& =11.8\left(1.67 \times 10^{8}\right) / .74 \\
& =2.66 \times 10^{9} \mathrm{cfs} / \mathrm{ft} \text { (of head) }
\end{aligned}
$$

At an average vertical fall of $25 \mathrm{ft}$, generation of low-head hydro energy equivalent to that used to produce the eight primary commodities in the United States would require an instantaneous flow rate of 106 million cfs (at least over the April-September period considered here as being applicable to most of agriculture's needs).

Inventories of low-head hydro sites are being developed by researchers in several states (Lomas et a1. 1978 Brow et a1. 1978) Further investigations and data compilation are necessary to identify those that may become part of energy-integrated farm systems. Many potential sites, such as irrigation canal wasteways, are already being developed for commercial electricity production. Much detailed investigative work remains to be done 
TABLE 3.5. Estimate of the Available On-Farm Stream Flow Energy During the Mean Farming Season, by Region

\begin{tabular}{|c|c|c|c|c|}
\hline Region & $\begin{array}{c}\text { Geographic } \\
\text { Area } \\
\end{array}$ & $\begin{array}{l}\text { Total Low-Head } \\
\text { Hydro Billion } \\
\text { Btu/yr(a) } \\
\end{array}$ & $\begin{array}{l}\% \text { of Low-Head } \\
\text { Hydro Located } \\
\text { On-Farm } \\
\end{array}$ & $\begin{array}{l}\text { Billion Btu/yr } \\
\text { Generated by } \\
\text { EIFS }\end{array}$ \\
\hline 1 & Northeast & 122,100 & 20 & 24,420 \\
\hline 2 & Southeast & 42,000 & 10 & 4,200 \\
\hline 3 & Midwest & 40,500 & 30 & 12,150 \\
\hline 4 & Northcentral & 24,300 & 30 & 7,290 \\
\hline 5 & Plains & 14,400 & 30 & 4,320 \\
\hline 6 & Texas-0k lahoma & 15,600 & 30 & 4,680 \\
\hline 7 & Mountain & 66,000 & 10 & 6,600 \\
\hline 8 & Far West & 162,000 & 10 & 16,200 \\
\hline
\end{tabular}

(a) Estimated by PNL from data published in "Inside DOE," October 5, 1979.

TABLE 3.6. Estimate of the Available Geothermal Energy During the Mean Farming Season, by Region (a)

\begin{tabular}{|c|c|c|c|c|}
\hline Region & $\begin{array}{l}\text { Geographic } \\
\text { Area }\end{array}$ & $\begin{array}{l}\text { Wellhead Thermal } \\
\text { Energy (Trillion Btu) }\end{array}$ & $\begin{array}{l}\% \text { of Farms } \\
\text { Available } \\
\text { to Energy } \\
\end{array}$ & $\begin{array}{l}\text { Upper Limit of } \\
\text { Estimated Con- } \\
\text { tribution to } \\
\text { EIFS (Trillion Btu) }\end{array}$ \\
\hline 1 & Northeast & 0 & -- & -- \\
\hline 2 & Southeast & 0 & -- & -- \\
\hline 3 & Midwest & 0 & -- & -- \\
\hline 4 & Northcentral & 0 & -- & -- \\
\hline 5 & Plains & 0 & -- & -- \\
\hline 6 & Texas-0k 1 ahoma & 0 & -- & -- \\
\hline 7 & Mounta in & 202,000 & $1-10$ & 11 \\
\hline \multirow[t]{2}{*}{8} & Far West & 163,000 & $1-10$ & 18 \\
\hline & Total & 365,000 & & 29 \\
\hline
\end{tabular}

(a) Based on identified high-temperature and intermediate-temperature resources listed in U.S. Geological Survey Circular 790 (Muffler 1979). Low-temperature resources are not included. 
before credible estimates of on-farm stream flow, by farm and county, could be made to show potential impacts of the resource toward displacing conventional energy use in production agriculture. However, estimates of low-head hydro availability are shown in Table 3.5 .

\subsection{GEOTHERMAL ENERGY AVAILABILITY}

High-temperature $\left(>150^{\circ} \mathrm{C}\right)$ and intermediate-temperature $\left(90-150^{\circ} \mathrm{C}\right)$ geothermal resources in the United States occur predominantly in the Western states. Quantitative estimates of recoverable thermal energy from these resources have been made by the U.S. Geological Survey (USG) (Muffler 1979). The USGS also estimated the electrical potential of each of the identified high-temperature reservoirs. Table 3.6 shows an estimate of the geothermal energy available to the energy integrated farm by region. As shown by this Table regions 7 and 8 have enough geothermal energy on a gross basis to meet about 9 percent of the need.

In addition to the resources discussed above, the USGS has tabulated data on low-temperature $\left(90^{\circ} \mathrm{C}\right)$ geotherma 1 resources. The amount of recoverable energy from these resources has not yet been estimated. However, low-temperature geothermal resources are thought to be available throughout the U.S. and to have the potential for significant agriculture uses.

\subsection{BIOMASS AVAILABILITY}

Biomass available for energy production includes crop residues, livestock manure and crops. Typical agricultural residue yields have been listed in Table 3.7, and the total energy available has been estimated in Table 3.8 from agricultural residues (Miles 1977). Pacific Northwest Laboratory (PNL) has used the 1978 USDA Agricultural Statistics to obtain crop acreages and residue yields from Table 3.7 to estimate the total energy available for each region.

As estimated in Table 3.9, more than $7 \times 10^{15}$ Btu of energy is available from crop and other renewable residues in the United States. Here again, this is the equivalent of nearly four times the amount of energy 
TABLE 3.7. Typical Agricultural Residue Yields

Wheat

Corn

Cotton

Soybean

Sorghum (grain)

Source: Miles 1977.
Residue

\begin{tabular}{ll}
\multicolumn{2}{c}{ Residue } \\
\hline Tons/Acre & Form
\end{tabular}

2.5

Straw

2.9

Stalks, Cobs

0.4 to 1.0

Gin, Trash

1.5

4.0

TABLE 3.8. Approximate Total Crop and Other Renewable Residues Developed in the USA

\begin{tabular}{lc}
\multicolumn{1}{c}{ Residues } & Quads (a) \\
\cline { 1 - 1 } Dry Residues & \\
Straws, Gin Trash, Nut She1ls & 2 \\
Damp Residues & \\
Soy, Sorghum Stalks, Rice Straw & 1 \\
Wet Residues & \\
Corn, Bagasse, Hops & $\underline{2}$ \\
Total Crop Residues & 5 \\
Manure & 2
\end{tabular}

(a) Quad $=1$ quadrillion Btu $=1.0 \times 10^{15}$ Btu. Energy values given are based on an average lower heat value (LHV) of $6000 \mathrm{Btu} / \mathrm{lb}$.

Source: Miles 1977. 
TABLE 3.9. An Estimate of the Biomass Energy Available Annually by Region

\begin{tabular}{|c|c|c|c|c|}
\hline \multirow[b]{2}{*}{ Region } & \multirow[b]{2}{*}{ Geographical Area } & \multicolumn{3}{|c|}{ Trillion Btu } \\
\hline & & Crop Residue (a) & Manure (b) & Tota1 \\
\hline 1 & Northeast & 370 & 174 & 544 \\
\hline 2 & Southeast & 459 & 191 & 650 \\
\hline 3 & Midwest & 1,645 & 290 & 1,935 \\
\hline 4 & Northcentral & 504 & 120 & 624 \\
\hline 5 & Plains & 1,487 & 321 & 1,808 \\
\hline 6 & Texas-0k 1ahoma & 735 & 320 & 1,055 \\
\hline 7 & Mountains & 416 & 182 & 598 \\
\hline 8 & Far West & 220 & 152 & 374 \\
\hline & Totals & 5,836 & 1,750 & 7,588 \\
\hline
\end{tabular}

(a) Includes corn stalks and cobs, soybean residue, wheat straw, cotton gin, field trash, and sorghum stalks.

(b) This is total manure available and does not necessarily represent that manure is readily convertible to energy. 
used in production agriculture $\left(1.78 \times 10^{15}\right.$ Btu $)$ each year. Biomass in the form of residues thus represents an abundant source of alternative energy available for energy-integrated farm systems in the United States.

The other major biomass resource available for conversion to energy is the crops grown by U.S. agriculture by conversion to ethanol. The total energy available as ethanol produced from major crops is shown in Table 3.10. Convertion of th corn, wheat, sugar beets, potatoes, and grain sorghum to ethanol would produce about 26 billion gallons of ethanol or about 2350 trillion Btu's as liquid fuel as compared to the liquid fuel needs of U.S. Agriculture of about 900 trillion Btu's (U.S. Department of Agriculture 1980).

\subsection{CONCLUSION}

Table 3.11 shows the availability of EIFS resources and demonstrates that there is more than ample renewable energy available in the various regions to satisfy the entire farm energy needs many times over. Table 3.11 also shows a tabulation of estimated maximum contribution by technology in each region. Obviously in any region the maximum contribution that could be made by any technology cannot exceed the total energy uses on the farms. Thus solar and biomass are shown at the limit of $100 \%$ of the energy needs of the farms, although they clearly have many times more resources than shown below. This is reflected in the appropriate columns in Table 3.12, which shows the energy availability by region in percent of that required.

Several conclusions can be inferred from these figures and the research that led to them:

a) Solar and biomass appear to be far ahead of other renewable resources as defined by the current thrust of energy research projects.

b) A vast increase in contribution by wind could result from the ability to economically use winds of less than $40 \mathrm{~W} / \mathrm{m}^{2}$ at $50 \mathrm{~m}$ height intensity.

c) Low-head hydro could contribute much more if co-op projects remotely located from the farmstead were included in the EIFS scope. 
TABLE 3.10. Energy Availability by Conversion of Major U.S. Crops to Ethanol

\begin{tabular}{|c|c|c|c|}
\hline Crop & $\begin{array}{l}\text { Total Production } \\
\text { (Million Tons) (a) }\end{array}$ & Ethanol (gals/ton) ${ }^{(b)}$ & $\underline{\text { Trillion Btu's }}^{(\mathrm{c})}$ \\
\hline Corn & 198 & 93 & 1,657 \\
\hline Wheat & 54 & 87 & 423 \\
\hline Sugar Beets & 26 & 20.3 & 48 \\
\hline Potatoes & 18 & 28.8 & 47 \\
\hline Grain Sorghum & 21 & 93 & $\underline{175}$ \\
\hline Total & & & 2,350 \\
\hline
\end{tabular}

(a) Source: U.S. Department of Agriculture 1979.

(b) Source: M. L. David, et. al., 1978.

(c) Calculated using Higher Heating Value of 90,000 Btu/gallon. 
TABLE 3.11. Potential Contribution by Various Resources to Energy-Integrated Farms Energy Needs (in trillion Btu's)

\begin{tabular}{|c|c|c|c|c|c|c|c|}
\hline Region & Geographic Area & $\underline{S o l a r}^{(a)}$ & Wind & $\begin{array}{l}\text { Low-Head } \\
\text { Hydro } \\
\end{array}$ & Geotherma l & Biomass & Regional Needs \\
\hline 1 & Northeast & 186 & -- & 24 & 0 & 186 & 186 \\
\hline 2 & Southeast & 231 & -- & 4 & 0 & 231 & 231 \\
\hline 3 & Midwest & 397 & -- & 12 & 0 & 397 & 397 \\
\hline 4 & Northcentral & 162 & -- & 7 & 0 & 162 & 162 \\
\hline 5 & Plains & 283 & 28 & 4 & 0 & 283 & 283 \\
\hline 6 & Texas-0k 1 ahoma & 232 & 23 & 5 & 0 & 232 & 232 \\
\hline 7 & Mountain & 113 & -- & 7 & 11 & 113 & 113 \\
\hline 8 & Far West & 182 & 18 & 16 & 18 & 182 & 182 \\
\hline Total & 1,786 & 69 & 79 & 29 & 1,786 & 1,786 & \\
\hline
\end{tabular}




\section{TABLE 3.12. Availability of EIFS Resources in}

Percent of Required Energy

\begin{tabular}{|c|c|c|c|c|c|c|}
\hline Region & Geographic Area & Solar & Wind & $\begin{array}{l}\text { Low-Head } \\
\text { Hydro }\end{array}$ & Geotherma l & Biomass \\
\hline 1 & Northeast & 100 & 0 & 13 & 0 & 100 \\
\hline 2 & Southeast & 100 & 0 & 2 & 0 & 100 \\
\hline 3 & Midwest & 100 & 0 & 3 & 0 & 100 \\
\hline 4 & Northcentral & 100 & 0 & 4 & 0 & 100 \\
\hline 5 & Plains & 100 & 10 & 1 & 0 & 100 \\
\hline 6 & Texas-0k lahoma & 100 & 10 & 2 & 0 & 100 \\
\hline 7 & Mountain & 100 & 10 & 6 & 10 & 100 \\
\hline 8 & Far West & 100 & $\underline{10}$ & 9 & $\underline{10}$ & 100 \\
\hline \multicolumn{2}{|c|}{ Overall Average } & 100 & 4 & 4 & 2 & 100 \\
\hline
\end{tabular}


These figures do not show, nor are they limited by, the match of resource to specific energy type, which is covered in the following chapter on the state of the technology. On the basis of these resource figures above, (Tables 3.11 and 3.12) the EIFS program would be proportioned to use $4 \%$ of the funds on wind, $4 \%$ on low-head hydro, $2 \%$ on geotherma 1 and $45 \%$ each on solar and biomass. 


\section{AN IDENTIFICATION OF TECHNOLOGICAL OPPORTUNITIES}

The purpose of this chapter is to identify technological opportunities to integrate renewable energy resources into farm systems and to estimate the contributions that they could make by the year 2000 .

Technological opportunities are defined as being created from the application of advances in knowledge found within the industrial and agricultural arts and that could be applied to farm energy production by 2000. The technologies of interest in this chapter are defined as: 1) solar, 2) wind, 3) geothermal, 4) low-head hydro and biomass technologies, 5) gasification, 6) pyrolysis, 7) combustion, 8) anaerobic digestion, 9) fermentation, and 10) liquefaction.

A technology must meet two requirements to qualify as an EIFS program opportunity: 1) the technology must be at the appropriate stage of development to justify government support 2) the technology must have a reasonable probability of being able to produce the kind of energy needed when it is needed. This chapter reviews each of the candidate technologies, discusses the energy conversion efficiencies of the technologies and then concludes with an evaluation of the technological opportunity for the EIFS technologies. The results of this chapter would indicate how much of the energy needed on the farm could be supplied by the various technologies if it were so located that it had good sunshine, plenty of wind, a good source of low-head hydro, a good geothermal source, etc. Obviously these conditions do not really apply but these limitations were addressed in Chapters 2 and 3.

\subsection{A REVIEW OF THE TECHNOLOGIES APPLICABLE TO ENERGY INTEGRATED FARM SYSTEMS (EIFS)}

Several technologies are considered in the literature to be applicable to collecting, generating, or transforming renewable energy for on-farm use. The following paragraphs generally describe these technologies and include descriptions of agricultural areas to which the technology can be applied. Current research on each application is also described. A subsequent section of this chapter will attempt to categorize the status of examples of these technologies according to their technological readiness. 


\section{1 .1 Solar}

Solar energy can be used to produce thermal energy and shaft or electrical energy. Shaft energy and electric energy are not differentiated because the solar technology available to produce one can easily be modified to produce the other.

\subsubsection{Thermal Energy Production}

Solar thermal energy can be collected and utilized by passive or active systems. Passive systems use the building or structure itself as the solar collector and thermal storage medium. Passive systems can be designed in a wide variety of configurations; the effectiveness of the passive design depends on the skill of the designer and the quality of construction. Active systems can be built using a variety of components and combinations of components, but they a 11 require blowers or pumps, a control system, pipes or ducts, collectors, and usually heat exchangers and thermal storage units.

Passive systems are applicable to all kinds of farm buildings. Though most successful when designed into a new building, successful retrofits to passive systems have been accomplished on well-oriented buildings at costs substantially below those of comparable active systems.

Active solar systems include grain drying, crop drying and curing, greenhouse and residential heating, livestock shelter heating, water heating, and animal waste dehydration. In-storage drying of wheat, sorghum, and corn with solar energy will be tested in a prototype model of a chemical dessicant drying system employing solar heat for dessicant regeneration, which will be developed. An economic study and cost analysis of alternative approaches to solar drying will be conducted. Collectors used for solar drying of corn, sorghum, and possibly wheat will include an air-inflated plastic collector; a rigid, flat plate collector; and a combination collector-storage system. In addition, solar energy stored in previous dried corn will be used for heating air at night (Mansfield et a1. 1977).

\subsubsection{Stationary Shaft Horsepower Production}

The two methods by which solar energy is used to produce shaft horsepower are thermal conversion using a thermodynamic cycle and direct 
photovoltaic conversion. A solar-powered irrigation plant has been built by Sandia Laboratories in Willard, New Mexico. Parabolic trough collectors with a north-south orientation and 622.4 meter $^{2}$ area are used to provide heat for operating and storage (Energy Research \& Development Administration 1977). The primary heat transfer fluid (Caloria HT43) operates at a peak temperature of $489 \mathrm{~K}$. The secondary fluid (Refrigerant 113) and the vapor turbine operate at a peak temperature of $436 \mathrm{~K}$. The variable speed turbine develops $36,300 \mathrm{rpm}$, which is reduced through a gearbox to $1760 \mathrm{rpm}$ at the output shaft. The system has a Rankine cycle efficiency of $15 \%$ and develops $25 \mathrm{hp}$. At a rate of $2.5 \mathrm{~m}^{3}$ per minute water is pumped from a $34 \mathrm{~m}$ deep well, irrigating $404.6 \mathrm{~m}^{2}$ of land.

The first large-scale use of photovoltaic cells to generate electricity for water pumping was put into operation at Meade, Nebraska, in August 1977 (Pytlinski 1978). The electric system has 29 panels arranged in two rows holding a total of 120,000 silicon-type photovoltaic cells. The peak power that each row can develop is about $25 \mathrm{~kW}$. About $6 \mathrm{hr}$ of energy storage is provided by lead acid batteries with a total capacity of $85 \mathrm{kWh}$. The direct current electricity produced by the cells is converted to alternating current by inverters. The $10 \mathrm{hp}$ pump motor can operate $12 \mathrm{hr}$ a day and deliver $3.8 \mathrm{~m}^{3}$ per minute of water from a reservoir.

\section{1 .2 Wind}

Wind turbines are larger than most farm windmills and resemble airplane propellers. A typical wind energy conversion schematic is shown in Figure 4.1. The maximum amount of energy that can be taken from the wind is $59.3 \%$ of the kinetic energy moving through a disc the size of the rotor. An American farm windmi 11 peaks out at about $31 \%$, while a Dutch windmill achieves about $17 \%$ and a modern two-blade turbine will exceed $45 \%$. If the gearing, generator, and transmission are $70 \%$ efficient, the best that can be expected is to convert about $32 \%$ of the wind energy into electricity. Using the shaft power directly to power a pump or to agitate water for heat will raise the overall system efficiency slightly. A vertical rotor (commonly referred to as the egg-beater style) has a maximum efficiency of about 35\%. These efficiencies are estimated for 


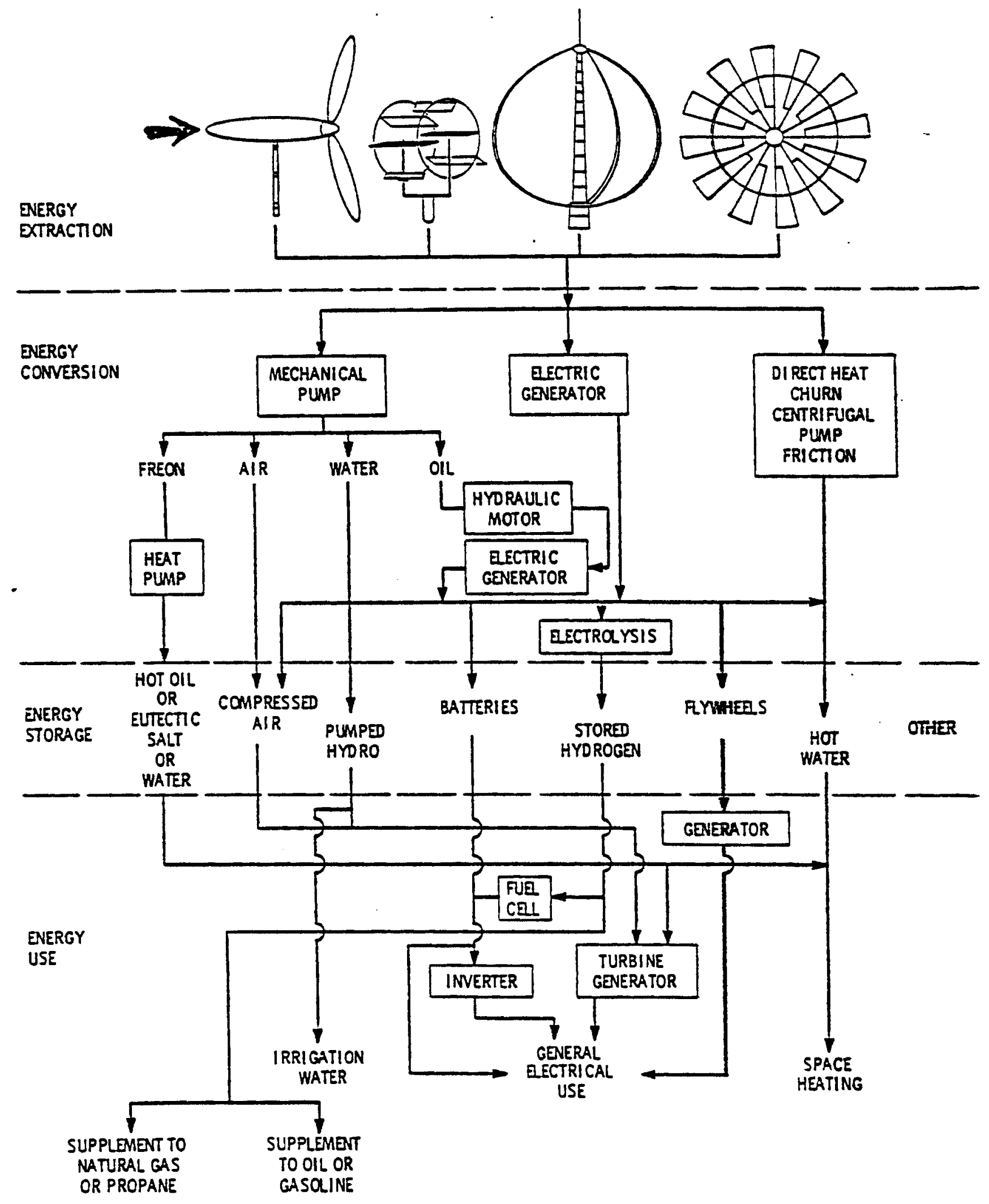

FIGURE 4.1. Wind Energy Conversion Systems 
design wind speeds. The efficiency is lower for higher or lower end speeds. Information about rotor types, efficiencies, blade tip speed ratios, etc., is included in Wealey et al. (1978).

Proper siting of wind energy conversion systems (WECS) is critical. The site needs to be analyzed for turbulence and interference from trees, buildings, and landforms, especially landforms that can accelerate wind flow at a certain height above the ground. For an indepth discussion of WECS siting see Wealey et al. (1978).

Wind energy can be utilized as shaft horsepower or thermal energy. Direct conversion of wind-generated shaft power is possible, but has not come into common use. A submerged pump or agitator will heat a fluid surrounding it and the efficiency of the process is relatively high. The heat has to be generated at or very near the wind power site to avoid the losses associated with transmitting mechanical energy for any distance by shafts, rods, or hydrautic lines.

Heating water or another suitable heat reservoir with wind electricity is an efficient way of storing thermal energy once the electricity has been generated. Battery storage of electricity is $60 \%$ to $80 \%$ efficient, but heat storage in an insulated water tank can approach 100\% efficiency. Machines for generating electricity from wind are commercially available and resistance heaters are also available for use with $A C$ or DC electricity in a wide range of voltages.

No machines are currently being sold for direct conversion of wind to heat, although the heating of water by direct conversion has been demonstrated. Generating high level-heat $\left(250-1000^{\circ} \mathrm{F}\right)$ by wind-driven friction is in the experimental stage.

Given a suitable site, a properly sized and installed wind machine, and adequate thermal or electrical storage, wind energy would be capable of heating any desired space. A wind/electric/thermal system could also supply electricity for other needs. 
As with all wind systems, the better the wind data from the proposed site the more accurately the system output can be calculated. For wind heating, it is important to determine the degree of correlation between wind velocity and heating demand. A wind survey that records length of calm periods will help determine the amount of storage needed or can dictate the need for a backup heating system.

Since batteries typically represent about $35 \%$ to $40 \%$ of the cost of a wind/electric system, a wind/electric/thermal system will be considerably less expensive than a wind/electric system of the same rated capacity. A typical wind/electric/thermal system of $10 \mathrm{~kW}$ rated capacity would cost $\$ 15,000$ and could be expected to provide about 30,000 kWh per year when located on a site with an annual men wind speed of $17 \mathrm{mph}$. If the cost of the $\$ 15,000$ capital is $\$ 1,740$ per year and maintenance costs add $\$ 250$ per year, the heat received will cost $6.6 \$$ per $k W h$. (a) If someone is presently paying $\$ 3.5 \$$ per $\mathrm{kWh}$, rise at a $9 \%$ increase per year, the average cost for the next 20 years will be $8.95 \$$ per $\mathrm{kWh}$ and the cost at the end of the 20 years will be $19.6 \%$ per kWh. Larger systems will produce heat for up to $25 \%$ less per $\mathrm{kWh}$, while smaller systems will produce heat at two to three times as much. Many simplifying assumptions have been made in this example. A complete study of power availability and cost for each specific site is the only way to predict cost and performance with any accuracy.

The traditional American farm windmill is still pumping water for livestock in arid range areas. Such windmills, built by companies that have been building windmills for 40 to 80 years, can still be purchased. Their simplicity, reliability, and the reputations of the manufacturers are excellent selling points, but these windmills also have their drawbacks. First, in a mechanical system the wind machine has to be located at the well, which sometimes is not a good place for wind. Second, their efficiency is not very good, although they do work better than a modern wind turbine if the winds are gentle.

(a) 20-year life, 10\% interest. 
Other factors that contribute to the benefits of farm windmills to pump water are cost and performance of mechanically-operated versus electric pumps for the depth of the we11, the number of animals and/or people to be supplied, and the amount of water storage that can be supplied.

The discussion has centered around use of shaft horsepower to pump water. Undoubtedly, other applications, such as splitting or sawing wood, exist for wind power, but justifying a wind energy conversion system (WECS) for these applications may be difficult. The biggest use of shaft horsepower on a farm is usually in tractors and combines, but running a tractor with a windmill is obviously not a practical solution: Using wind-generated electricity to produce hydrogen fuel by hydrolysis is a possibility but hydrogen technology is still essentially in the laboratory, and diesel fuel prices will have to rise dramatically (a distinct possibility) to make such a scheme financially viable.

The technical requirements for utilizing wind energy for shaft horsepower are: 1) analysis of energy available at the site, 2) analysis of power requirements for the particular application, and 3) analysis of storage required to match supply and demand.

While a simple farm windmill for running a pump can be obtained for a few hundred dollars, a more elaborate system wi11, of course, cost more. For example, a 2,000 watt generating system will cost approximately \$4,400 without batteries, which is less than most we11/pump setup costs. The cost of a water storage tank and/or batteries to store electricity must be added. Batteries should cost about $\$ 2,600$ for a $2 \mathrm{~kW}$ system. Power cost from this system at a good site would be roughly 17-20\& per. kWh, which still may be much less expensive than running a utility line to the site.

A large system for pumping irrigation water could supply power for as little as $8 \$$ per $\mathrm{kWh}$, but storage in a reservoir or in batteries would probably add another 2 to $3 \phi$ per $k W h$ unless the crop is hardy enough to be irrigated only when the wind blows, which would eliminate the need for electricity storage. 
Before rural electrification, many farms had wind chargers. Some of these are still available, virtually unchanged from the original design, from the original manufacturers. Most of the wind machines on the market now were designed to generate electricity. Traditionally, wind electricity has been low voltage DC. DC electricity has many uses, but also has disadvantages. The motors of many household appliances will not work on $D C$ electricity. Basically three ways of obtaining 60 cycle AC power from the wind are available: 1) control the wind turbine speed within narrow limits and drive an alternator (for very large systems this may be practical, but probably not for a small unit); 2) generate $D C$ and use it to power an inverter (many inverters are on the market and in use); or 3) use a field modulated generator, which will produce fixed-frequency $A C$ at varying speeds.

Electricity is probably the second most versatile energy form. Once it has been generated, the uses are endless; however, some study is necessary to choose the best voltage and whether $A C$ or $D C$ is best for the needed applications. The conversion of mechanical energy to electrical energy requires fairly complicated technology, but integrated systems are on the market. Still, the better wind energy conversion is understood by the buyer, the better chance he has of buying the system that fits his application needs.

As with all wind systems, knowledge of the resource (wind) and the demand will better enable design of a successful system. The factors that influence costs are basically the same as for all wind systems. Knowledge of the average wind speed, preferably on a month-by-month basis, is the most important factor.

\subsubsection{Low-Head Hydro}

Two trends toward use of stream flow for energy production for farm and farmstead use are prevailing. The first and most technically sound approach is the low-head and very low-head hydroelectric engineering concepts (Gladwell and Warnish 1978). The second is the rejuvenation of past (though perhaps obsolete) technology for individual rural use, as exemplified in such books as The Handbook of Homemade Power (The Mother Earth News 1974). Typical water power methods discussed in the book 
include impulse (Pelton) wheels, overshot water wheels, small-scale Francis or propeller (reaction-type) units, and hydraulic ram pumps.

Low-head hydro is usually assumed to pertain to hydroelectric works operating at less than $50 \mathrm{ft}$ of head. Very low-head hydro applies to those situations with 25 or less feet of head. The basic physical relationship between head, rate of stream flow, and generating efficiencies is expressed as:

$$
P=\frac{Q H}{11.8} e^{e}
$$

where

$$
\begin{aligned}
P= & \text { instantaneous power generated in } \mathrm{kW} \\
Q= & \text { flow rate through the system in cfs } \\
H= & \text { gross head in feet } \\
e= & \text { relative conversion efficiency of the installation (technology } \\
& \text { dependent) }
\end{aligned}
$$

For example, a farm stream dammed with a head of $10 \mathrm{ft}$, a flow rate of 2,000 cfs and a conversion efficiency of $80 \%$ would potentially provide 1,356 kW of power.

Conversion efficiencies for low-head and very low-head hydro installations have been found to vary from $75 \%$ to $85 \%$. Conversion efficiencies generally improve toward the higher value as flow rate (discharge) and head both increase (Mercer 1978 ).

Turbine generators manufactured both in the U.S. and in Europe have gone through several stages of refinement. However, major improvements can yet be made in standardization and mass production of low-head hydro equipment, according to people in the industry. This improvement would significantly lower the unit cost. In addition, low-head hydro equipment is believed to have suffered from a lack of research and development due to neglect of the technology over the past several decades. However, the technology is, for the most part, commercially and readily available.

Capital costs, normally have been estimated to be approximately $\$ 1,000$ per $\mathrm{kW}$ of installed capacity. A reasonable range might be $\$ 750$ to $\$ 2,000$ per $\mathrm{kW}$, depending on specific siting and capacity considerations. 

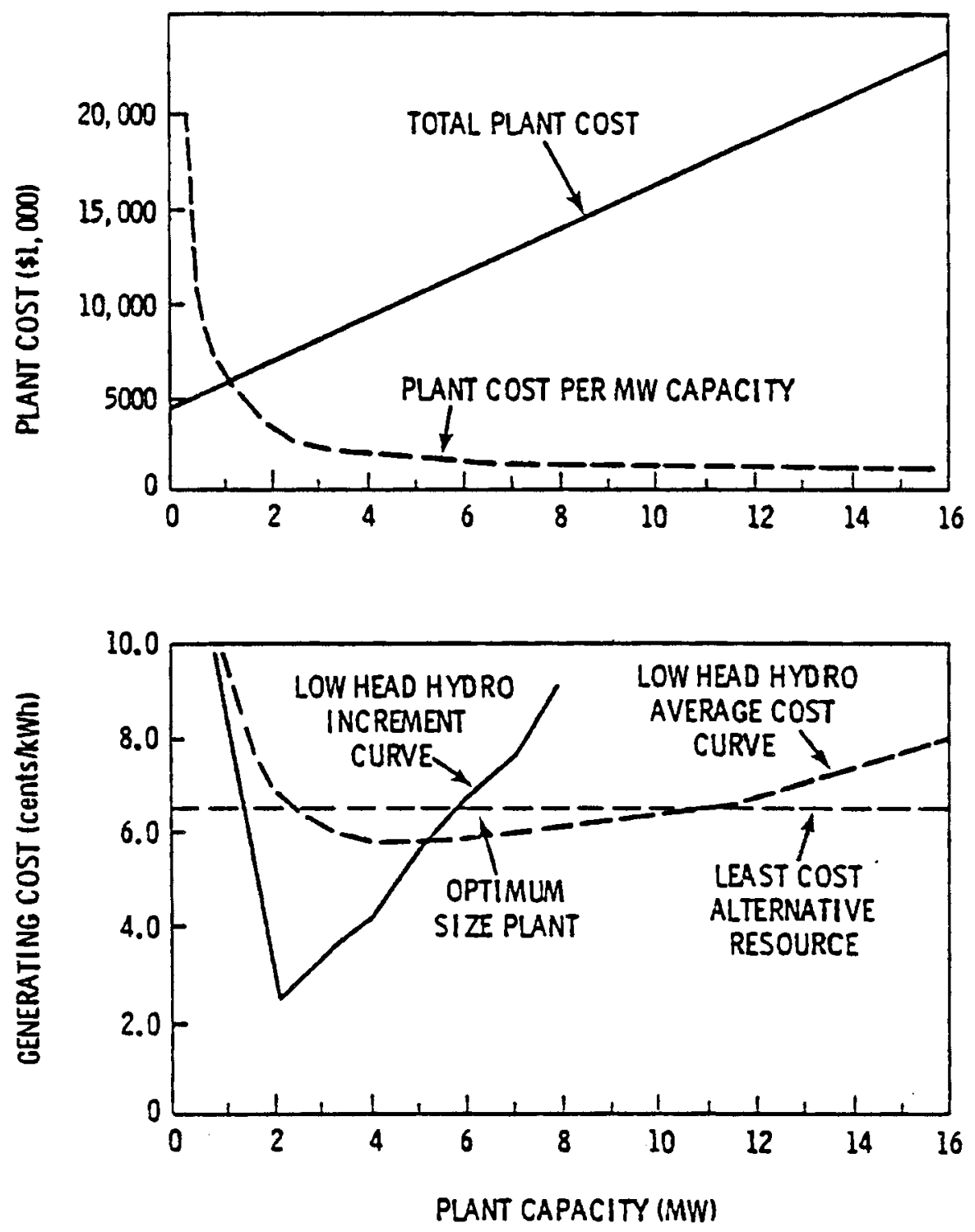

FIGURE 4.2. Estimated Low-Head Hydro Capital and Generating Costs as a Function of Plant Capácity 
Operating costs typically range from 10 to $70 \mathrm{mills}$ per $\mathrm{kWh}$. Typical cost curves for capital and operating conditions are illustrated in Figure 4.2.

- Impediments to adapting this alternative energy form have included:

- 1icensing procedures (water rights, siting, environmental impacts, etc.)

- seasonality of stream flows

- capital intensive nature of the projects

- extreme site dependency (season, stream size, energy demands, etc.)

- potential sites may be too large (and too costly) to serve individual farms yet too smal1 to serve rural communities

- high engineering and construction costs of one-of-a-kind installations. Factors contributing to future adoption of this energy technology include:

- a we11-developed technology (but perhaps suffering from R\&D neglect) for low-head hydro equipment and design capabilities

- relatively low operating cost for electrical generation once installed.

Many such low-head hydro sites have been abandoned in recent decades in the United States. These sites, many in rural areas, might very well be potential sites for power generation as part of energy-integrated farm systems.

Very low-head and low-head hydroelectric generation is an extremely attractive energy substitution technology for farm energy systems, primarily for irrigation pumping and farmstead electrical energy requirements (1ighting, heating, motive power, and farm shop uses such as welding, etc.). The potential is believed available to significantly achieve relative energy independence if pursued as part of an integrated or packaged energy system for American farms.

\subsubsection{Geothermal}

Applications of geothermal energy to the agricultural industry range from electrical production to animal husbandry to greenhouses. In this section, existing uses of geothermal energy are identified, and existing and 
possible applications of these resources to the agricultural industry are 1 isted.

The total potential usuable geothermal energy in the U.S. has been estimated by the U.S. Geological Survey (Muffler 1979). Recoverable resources, both discovered and undiscovered, may result in 150,000 MWe of power for 30 years in the United States alone. Most Known Geothermal Resource Areas (KGRAs) are located in the Western United States. Large geopressured resources are found along the Texas-Louisiana coast and radiogenic heat sources can be found along the Eastern Seaboard.

At present, geothermal resources around the world are being utilized for both electrical power production and nonelectric applications. Approximately 1400 MWe are now being produced, in addition to over 7,000 MWt of peak nonelectric use. Electric power available from geothermal heat by 1983 for the United States is estimated to be 1921 MWe (Rex 1978). Nonelectric use of geothermal resources in the United States by 1985 is projected to be 0.1 quad/yr or 3,340 MWt (Department of Energy 1977).

The use of geothermal heat in the agricultural industry is not only an efficient use of that resource, but also contributes to the solution of the pressing problem of adequate food supplies. A 26,000 $\mathrm{ft}^{2}$ greenhouse in Oregon is currently growing tomatoes and uses geothermal energy to maintain a year-round temperature of $70^{\circ} \mathrm{F}$ (Head 1970).

\subsubsection{Biomass Technologies}

\subsubsection{Gasification}

Gasification of combustible solids involves the partial combustion of the solid to generate a combustible gaseous mixture called synthesis gas. Other products of the process can be a condensable liquid (tars) and an ash or carbonaceous residue. The gasifying medium can be oxygen, air, steam, $\mathrm{CO}_{2}$, or a mixture of these gases.

Possible end products from gasification of wood as a representative renewable resource are illustrated in Figure 4.3. All of these products cannot be generated together; the products listed are options. For example, either 0.7 tons of anhydrous ammonia, or 0.67 tons of methanol can be obtained, not both. 




FIGURE 4.3. Possible Products from Agricultural Residues (a)

(a) The residues are also assumed to provide the needed process heat. The yield figures shown here take their requirement into account to obtain the net yields as shown. 
The following discussion presents the technical stage of development of the technologies illustrated by Figure 4.3. All of the technologies required to generate the products from the synthesis gas are commercially available. These processes currently use synthes is gas generated from reforming of natural gas. No commercial system for the generation of synthesis gas from wood is available. Technology for generation of synthesis gas is in the demonstration phase, such as the Purox process (Moses et a1. 1978); and engineering development phase, such as the Battelle, Garrett Energy Research and Engineering, Wright-Matta processes (Sealock et al. 1978).

A moving bed, also known as a fixed bed, air-stream blown-type of gasifier for generation of a low-Btu gas is the only gasification system that has had significant commercial applications using wood as the solid fuel (Mikesell et a1. 1978). The low-Btu gas can be used as a heat source. It can be combusted to raise steam or to dry agricultural crops (Coffman and Hooverman 1978). It can be used as a fuel for an internal combustion engine, or as a reducing gas in the steam-iron process to generate hydrogen for synthesis of nitrogenous fertilizers (Moses et al. 1978).

Production of nitrogenous fertilizers (ammonia) from wood was practiced commercially in India in the 1940s (Rutherford and Ruschin 1949). The process used the low-Btu gas as a reducing gas for the steam-iron process to generate $\mathrm{H}_{2}$ and was therefore quite inefficient. The scheme illustrated in Figure 4.3 shows the potential for generating one ton of anhydrous ammonia from 2.0 tons of wood. whereas the process used in India required about 5 tons of wood per ton of anhydrous ammonia.

Economics of gasification systems for generation of a low-Btu gas or an intermediate-Btu gas from wastes and biomass are presented in several sources (Skov and Papworth 1975; and Frit et al. 1978). The costs may be optimistically low since they represent the costs of using systems that are being promoted by developers. With zero cost for the solid fuel and a $60 \%$ conversion efficiency, a low-Btu gas would cost from 3.12 to 0.783 dollars per million Btu for a 20 ton/day and a 200 ton/day, respectively (Bailee 1976). Medium-Btu gas from the Purox system costs 
$\$ 2.55$ and $\$ 4.1$ per million Btu for the 850 ton/day and 3,400 ton/day capacities, respectively, with a wood fuel cost of $\$ 1.00$ per million Btu (B1iss and Blake 1977). At a wood fuel cost of $\$ 2.50$ per mi11ion Btu, the costs for the respective plant sizes are given as $\$ 4.15$ and $\$ 4.68$ per miliion Btu.

Processes now in the engineering development phase should improve the conversion efficiency and the process economics.

\subsubsection{Pyrolysis}

Pyrolysis of combustible solids involves applying heat in the absence of oxygen to destructively distill the solid. Pyrolysis products include a medium-Btu gas, charcoal (carbonaceous residue), and a condensable liquid (tars and pryoligneous acids).

\subsubsection{Direct Combustion}

Combustion (or incineration) of agricultural biomass is the direct means of obtaining thermal energy from this resource. This thermal energy can be used directly or can provide either shaft-horsepower or light as other end uses. Although direct combustion by itself cannot provide liquid fuels, gaseous fue1s, fertilizers or chemicals, it could be used as the energy source in the production of these other end-use forms.

The uses of direct combustion as an energy source are shown in Figure 4.4. As shown in the figure, hot flue gases are generated by direct combustion in a furnace (incinerator). The hot flue gases are ideally suited for direct drying of several "nonfood" crops such as feed grains, alfalfa and other hay where slight amounts of ash in the flue gas would not affect the product. Even for certain food crops, the hot flue gases could possibly be used with little or no ash removal. However, potential changes in taste or other harmful results should be considered for each specific use.

The hot flue gases can also be used to produce steam in a boiler. In this application, the furnace and boiler are usually combined in one unit. The steam that is generated can be used to provide shaft-horsepower 


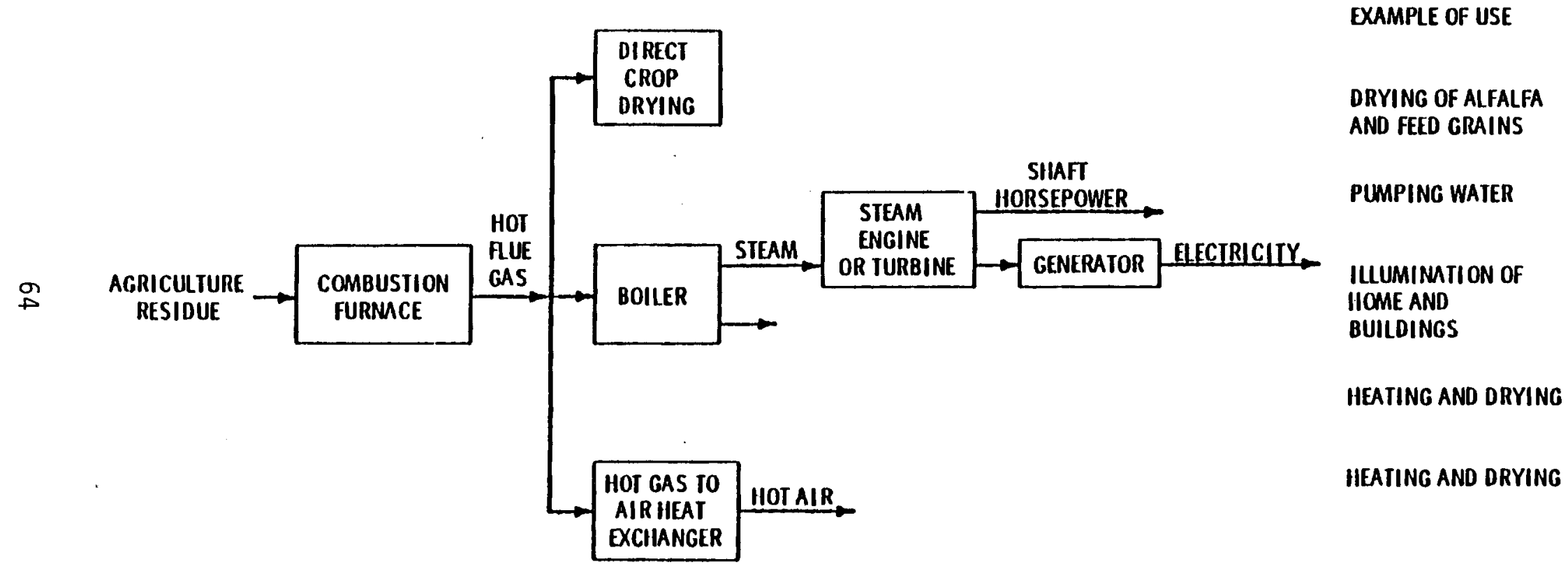

FIGURE 4.4. Combustion of Residues for Energy 
via either a steam engine or a turbine. The shaft horsepower produced can be used to replace the current uses of shaft horsepower on the farm (i.e., pumping water, conveying, and motive energy). However, shafthorsepower derived from steam appears to be most applicable to those cases where the energy need is stationary, such as pumping irrigation water, because of the bulkiness of the system. This shaft horsepower can also be used with a generator to provide electricity for home, barn, and greenhouse illumination. The electricity can also be used to supply several small requirements for shaft horsepower where direct use of steam would not be convenient. In addition to providing shaft horsepower, the steam can be used as a thermal energy source for drying and heating applications.

The hot flue gases can be used to heat air in a "gas to air" heat exchanger. The heated air can then be used for crop drying and space heating. This heated air does not contain the ash or the combustion products and can be used for drying food crops for which the direct use of the flue gas would not be applicable, or for space heating where the combustion products might be toxic.

The form of agricultural residue used for direct combustion can vary depending on application. The forms include hammermilled straw, stalks, bales, cubes, and pellets. Thomas R. Miles (1975) describes a bale-burning furnace that can be used on-farm for dehydrating systems. For furance or furnace/boiler applications where coal or wood are now being used (or could be used), the fuel size depends on the combustion chamber design. For example, fuel particles for a typical grate system for wood are 2 to $3 \mathrm{in.,} \mathrm{while}$ much smaller particles are used in suspension systems (USDA-Forest Service 1976). For best combustion, the residue should be dry (less than $15 \%$ moisture) as recommended by manufacturers of wood-burning furnaces (NASA/ASEE Systems Design Institute 1974). However, fuels with higher moisture content can support combustion and some of the energy from combustion can be used to predry the fuel.

Although the technology for utilizing agricultural residues as an energy substitute via direct combustion is available, it is not currently 
being extensively practiced on the farm level. In the not-too-distant past, straw was used to provide energy for threshing grain. The equipment and technologies for the combustion of agricultural residues are very similar to that for hogged fuel and coal. The energy content of most agricultural residues (straw, etc.) is about $8,000 \mathrm{Btu} / 1 \mathrm{~b}$ on a dry basis, which compares to wood, also at about $8,000 \mathrm{Btu} / \mathrm{lb}$. The main concern in utilizing these residues is the collection, transportation, storage, and handling problems encountered in delivering the given residue to the energy production site.

\subsubsection{Anaerobic Digestion}

Anaerobic Digestion is the conventional method of processing sewage to minimize water pollution by destroying the principal, oxygen-demanding organic matter. In some cases, the resulting dilute methane gas has been productively used to provide the fuel for steam and electricity for disposal plant operation. Recent emphasis on conservation and improved environmental control has increased interest in wide-scale use of anaerobic digestion for methane fuel production. Such practical applications of the process are currently limited to large-scale tests and demonstrations on feed-lot manure and municipal waste (sewage) and solid waste conversion.

An aqueous slurry containing about $10 \%$ by weight of the organic solids suitably prepared (usually by grinding and inoculation by at least two suitable strains of bacteria generally already present in the fermentation feed or residues) is held in large closed tanks at elevated temperatures (above $95^{\circ} \mathrm{F}$ ). Some agitation is desired. Over a retention time of 2 to 3 weeks, about $50 \%$ of the organic fraction (principally the carbohydrate fraction) is fermented, resulting in a gas containing about $60 \%$ methane and $40 \%$ carbon dioxide.

Anaerobic treatement of complex organic materials is normally considered to be a two-stage process. In the first stage the complex organics are changed in form by a group of facultative and anaerobic bacteria commonly termed the "acid formers." Complex materials such as fats, proteins, and carbohydrates are hydrolyzed, fermented, and biologically converted to 
simple organic materials. For the most part, the end products of this firststage conversion are organic fatty acids. Acid-forming bacteria bring about this initial conversion to obtain the small amounts of energy released for growth, and a small portion of the organic waste is converted to cells. Although no waste stabilization occurs during the first stage of treatment, it is required to place the organic matter in a form suitable for the second stage of treatment.

In the second stage of methane fermentation real waste stabilization occurs. During this stage, the organic acids are converted by a special group of bacteria termed the "methane formers" into the gaseous end products, carbon dioxide and methane. The methane-forming bacteria are strictly anaerobic and even small quantities of oxygen are harmful to them. Several different groups of methane formers exist, and each group is characterized by its ability to ferment a relatively limited number of organic compounds. Thus, in the complete methane fermentation of complex materials, several different methane bacteria are required. The methane formers that use materials such as formic acid and methanol grow very rapidly and can thrive at sludge retention times of less than two days. However, the most important methane formers, which live on acetic and propionic acids, grow quite slowly, and retention times of four days or longer are required for their growth. These bacteria carry out the major portion of waste stabilization. Their slow growth and low rate of acid utilization normaliy represents the limiting step around which the anaerobic treatment process must be designed.

The anaerobic treatment process does have some disadvantages that may limit the use of this process for certain applications. The major disadvantage is that relatively high temperatures are required for optimum operation; temperatures in the range from $85^{\circ}$ to $95^{\circ} \mathrm{F}$ are preferred. Dilute wastes may not produce sufficient methane for waste heating and this may represent a major limitations.

Buswell and Mueller (1952) developed the following equation to predict the quantity of methane from a knowledge of the chemical composition of the waste: 


$$
\mathrm{C}_{n} \mathrm{H}_{\mathrm{a}} \mathrm{O} b+\left(\mathrm{N}-\frac{\mathrm{a}}{4}-\frac{\mathrm{b}}{2}\right) \mathrm{H}_{2} \mathrm{O} \rightarrow\left(\frac{\mathrm{n}}{2}-\frac{\mathrm{a}}{8}+\frac{\mathrm{b}}{4}\right) \mathrm{CO}_{2}+\left(\frac{\mathrm{n}}{2}+\frac{\mathrm{a}}{8}-\frac{\mathrm{b}}{4}\right) \mathrm{CH}_{4}
$$

Although livestock wastes and crop residues have a complex mixture of fats, proteins, and carbohydrates, they are composed primarily of carbohydrates that have an empirical formula of $\left(\mathrm{CH}_{2} \mathrm{O}\right) \mathrm{n}$. These carbohydrates include starch and cellulose, which both have the same chemical formula of $\mathrm{C}_{6} \mathrm{H}_{10} \mathrm{O}_{5}$ but differ by the linkages of the groups forming the polysaccharides. For carbohydrates the above digestion equation yields:

$$
\mathrm{C}_{6} \mathrm{H}_{10} \mathrm{O}_{5}+\mathrm{H}_{2} \mathrm{O} \rightarrow 3 \mathrm{CO}_{2}+3 \mathrm{CH}_{4}
$$

Not all of the carbon dioxide is released as a gas but enters into reactions with water and hydrogen ions. Therefore, the gas composition is about 60 percent methane and 40 percent carbon dioxide rather than the $50 / 50$ mixture as would be predicted by the above equation. Theoretical gas generation is about $6.65 \mathrm{ft}^{3}$ of methane per pound of carbohydrate. For feedstocks that are primarily carbohydrates, the theoretical methane generation is also about $6.65 \mathrm{ft}^{3}$ per pound of volatile solids (total organic matter). In actual practice, conversion efficiencies are on the order of 80 to 90 percent so that practical methane production is about $5.6 \mathrm{ft}^{3}$ per pound of volatile solid.

\subsubsection{Fermentation}

In alcohol fermentation (also generally called fermentation) yeasts are employed to convert sugar to ethanol. In addition to crops actually containing sugar, those containing other carbohydrates such as starch and cellulose, which can be converted to sugar, can be used for ethanol production. Conversion of starch crops to sugar utilizes commercial enzymatic hydrolysis processes. The conversion of cellulose to sugar by enzymatic or acid hydrolysis is a more complex process than hydrolys is of starch. Because of this complexity, the use of cellulose to produce ethanol is normally not considered to be commercial.

Cooking is the first step in ethanol production from starch. The starch concentration is adjusted to about 15-20 percent by adding water and 
amylase enzymes and the resulting slurry cooked at about $200^{\circ} \mathrm{F}$ for $2-1 / 2$ hours . This cooking step converts the starch to dextrins (polymeric sugars). The dextrins are then converted to glucose by lowering the temperature to $122^{\circ} \mathrm{F}-140^{\circ} \mathrm{F}$ and adding glucoamylose, the enzyme used for saccharification (conversion of dextrins to glucose). The mash is now ready for the fermentation step in which yeasts of the strain Saccharomyces cerevisiae convert glucose to ethanol and which is summarized as:

$$
\begin{aligned}
& \mathrm{C}_{6} \mathrm{H}_{12}{ }_{6} \text { yeast } 2 \mathrm{C}_{2} \mathrm{H}_{5} \mathrm{OH}+2 \mathrm{CO}_{2}+\text { heat } \\
& \text { (glucose) (ethano1) (carbon dioxide) }
\end{aligned}
$$

The ethanol solution that is produced is called "the beer" and ranges in concentration from 8 percent to 12 percent ethanol by volume. The ethanol concentration is increased by distillation to a maximum concentration of 96 percent ethanol at the azeotrope. An azeotropic distillation process is conventional1y used to produce 100 percent (200 proof) ethanol.

The $\mathrm{pH}$ of the initial slurry to be used in cooking should be nearly neutral. The $\mathrm{pH}$ can be adjusted by adding dilute sodium hydroxide if the $\mathrm{pH}$ is too low or concentrated sulfuric acid or lactic acid if the $\mathrm{pH}$ is too high.

The conversion of the starch component of grains to ethanol via fermenation is presently state-of-the-art. The economics are often unfavorable for sma11-scale operations. For large-scale operations, the economics are heavily dependent on raw material (grain) cost and also on credit for the massive quantities of by-product which result. The conversion of cellulosic materials (stalks, straws and leaves) to ethanol via fermentation is not presently state-of-the-art. Although much research as been done in part, particularly for wood conversion by this process, no economical sustained operation of commercial facilities appears ever to have been maintained in the U.S.

Fermentation processes require energy input in the form of heat to recover the alcohol from the dilute fermentation liquors by distillation. However, these energy inputs can most likely be obtained from combustion of field residues (stalks, straws, etc.). Although fermentation to 
produce ethanol is a well-established business (production of premiumvalued ethanol for food-based uses), this process is also acknowledged to be generally more costly and in some studies substantially more costly than ethanol produced synthetically by the much larger petrochemicalbased industries. However, both biological processes show improved comparative economics as the price of fossil fuel resources (natural gas and petroleum) escalate.

\subsubsection{Liquefaction}

Thermochemical liquefaction is a process whereby almost any carbonaceous material (excluding coal and oil) can be treated with heat and alkali and converted to a liquid product. Since carbonaceous residues of biological origin contain the same four basic ingredients (cellulose, hemicellulose, lignin, and protein), the process can utilize wheat straw, other crop residues, hog and cow manure, sewage, wood waste and paper. When heated to a temperature of 300 to $400^{\circ} \mathrm{C}$ in a sealed vessel under alkaline conditions ( $\mathrm{pH}$ about 10$)$ for up to $1 \mathrm{hr}$, a mixture of water-soluble organic materials, water-insoluble "oil" and gas is formed.

Relatively little is known about the chemistry of this process. It is different from pyrolysis in that the cellulose portion of the biomass is digested to smal1 molecules such as acetone, which then recombine to give the oil product. The lignin and hemicellulose portions have not been studied in detail as the cellulose has, but with similar properties they presumably have similar chemistry. The organic materials in the water-soluble fraction may be intermediates in the degradation and resynthesis pathway, and hence could be recycled. Protein materials in alkali would generate ammonia gas (recoverable), and small molecules similar to intermediates in cellulose degradation (acetaldehyde, etc.), which would then enter the cycle and would also yield oil. Hence, all of the organic materials would be digested.

The yield of oil product achievable from liquefaction ranges from $30 \%$ to $50 \%$. The overall product from liquefaction is a viscous oil, with a heating value in the range of 12,000 to $15,000 \mathrm{Btu} / 1 \mathrm{~b}$, compared to a value 
of 7,526 Btu/lb for pure cellulose. Thus, although only a half of the initial weight of carbonaceous residue is produced as oil, almost all of the initial energy content is retained. The only major cost in energy is the amount required to perform the conversion.

The initial product itself is a poor liquid fuel. If distilled, it can be separated readily into a light oil useful as a liquid fuel, and a thick black tar, which can either be burned in a special boiler, or be more usefully used as a road paving material (asphalt substitute).

Thermochemical liquefaction, like all of the related processes, is currently in the applied research stage of development. Using current knowledge, it could be built and made to work, but so far none of these systems have been built and installed, and insufficient information is known about possible problems.

On a farm, a central collection area could consist of a haystack (if manure is not to be used as a substrate), or an enclosed tank with a screw transfer system connected directly to the reactor. If sewage and/or animal manure is to be used primarily, the storage tank could be common with storage for an anaerobic digester for methane production. The material entering the reactor tank would have to consist of particles less than $1 \mathrm{in}$. in diameter for optimum conversion; smaller particles would require a shorter residence time. They would be mixed with twice their volume of water (unpurified water or reaction recycle water), sodium carbonate added and mixed in to bring the $\mathrm{pH}$ to about 10, and the slurry heated to $350^{\circ} \mathrm{F}$ for about $20 \mathrm{~min}$ to $1 \mathrm{hr}$. As an alternative to a continuous reactor, a batch system could also be used. The product gases would consist mainly of carbon dioxide, steam, and small amounts of carbon monoxide, methane, ethane, etc., and would be of little value. They could be flared or passed over a catalytic oxidizer to prevent poliution. The liquid product would be poured off from the bottom of the reactor and would consist of an aqueous layer (lower) and an oil layer (upper), which could be easily separated. Some of the aqueous layer could be recycled, although some would have to be removed from the process at each pass due to the buildup of sodium salts from the alkali added. The rejected portion of the aqueous layer could be added to an 
anaerobic fermenter for complete recovery of carbon values and water cleanup. The oil product could be: a) burned directly in a special boiler, b) distilled to a light fuel oil suitable for machinery operation, and c) used as an asphalt fraction that could be either burned or used as a road paving base with aggregate gravel available on the farm. The only residue would be the reject water, which could be purified in conventional systems.

An alternative use for the oil produced would be to subject it to a second hydrogeneration step to obtain a high yield of a gasoline substitute. The process is extremely simple in principle and a conservative basis has been used for the material balance, based on PNL experimental results. Literature data (Kaufman and Weiss 1975) on this topic vary widely and are of dubious validity in many cases. Yields of up to $58 \%$ have been claimed for thermochemical conversions to oil, while $33 \%$ is norma 1 in PNL experiments (the range was $1 \%$ to $45 \%$ in 130 experiments). Also, PNL has used primarily pure cellulose; lignin would increase the yield somewhat over these results. Hence, PNL has used $33 \%$ yield of oil as their basis, with an average heating value of $13,000 \mathrm{Btu} / 1 \mathrm{~b}$, derived from a carbonaceous residue with a heating value of $7,500 \mathrm{Btu} / 1 \mathrm{~b}$ (dry). The oil itself can be separated into a net 16\% yield of asphalt-like residuum and $17 \%$ of 1 ight fuel oil directly through distillation at up to $250^{\circ} \mathrm{C}$ under vacuum. Value of the fuel $0 i 1$ and of the residuum is assumed to be $\$ 100 /$ ton, which corresponds fairly closely to the asphalt price of $\$ 100 /$ ton and the crude oil price of $\$ 15 /$ barrel.

The simplest thermochemical liquefaction variant, therefore, has wide potential applicability to farm use, provided some basic research is done to establish equipment design parameters.

\subsection{EFFICIENCIES OF CONVERSION}

Efficiencies of converting renewable resources into usable energy forms determine the ultimate practicality and economic motivation for adopting or not adopting a substitution technology for an integrated system of energy production on farms in the United States. Ranges of conversion efficiencies for each general resource and/or technologies 
are given in Table 4.1. Biomass conversion technologies offer the widest range of applications among the alternate energy technologies, one process perhaps being more adaptable to a given feedstock than another, depending on the location, climate and nature of the energy demand.

\subsection{THE TECHNOLOGICAL OPPORTUNITY FOR CANDIDATE EIFS TECHNOLOGIES}

This section attempts, somewhat subjectively to integrate the judgment of the contributors to this report into an assessment of the opportunity for various technologies to contribute to the specific types of needs of the EIFS. This section doesn't try to consider whether resources are available or consider the quantities of energy needed in these various categories. (These were assessed in the previous chapters).

Table 4.2 attempts to evaluate the "conversion technology potential" as a percent of energy that could be supplied if a good resource were available. For example, it is estimated that 40 percent of the electricity needs (not including irrigation) could be supplied by wind energy. 
TABLE 4.1. Energy Recovery Efficiency for Substitution Technology

Substitution

Technology

Solar

Wind

On-Farm

Geotherma 1

Biomass Conversjion

Pyrolysis

Biomass

Combustion

Anaerobic Digestion

Fermentation

Liquefaction

\section{Energy Recovery Efficiency}

Up to $80 \%$ efficiency for low temperature heating; $12-18 \%$ efficient for electrical production via solar cells. Available Power $=0.5 \mathrm{DAS}^{3}$ (where $D=$ air density, $A=$ area of rotor disc, $S=$ wind speed) Efficiencies of units vary from $15-40 \%$.

$P=$ $11.8^{\mathrm{e}}$

(where $P=$ instantaneous power in $k W, Q=$ flow rate in cfs, $H=$ head in $\mathrm{ft}$, e = conversion efficiency) Efficiencies vary from 75 to $85 \%$.

Thermal range varies widely; efficiency depends on temperature and pressure of source and end-use.

Gas production: $70-80 \%$ efficient.

Charcoal production: $40 \%$ efficient.

All other products: $90 \%$ efficient.

Hot gas for drying: $85 \%$ efficient.

Steam generation: $77 \%$ efficient.

Energy conversion to methane: $60 \%$ efficient.

$45-50 \%$ energy efficiency for conversion to ethanol. $48 \%$ energy efficiency on conversion to liquid fuel.

(a) Feedstock: Agricultural residues with energy content of $6,000-8,000$ Btu per pound. 
TABLE 4.2. Percent of End Use Energy Form that Could be Supplied by the Substitution Technologies (Reflects Both Stage of Development and Expected Ability to be Feasible) (a)

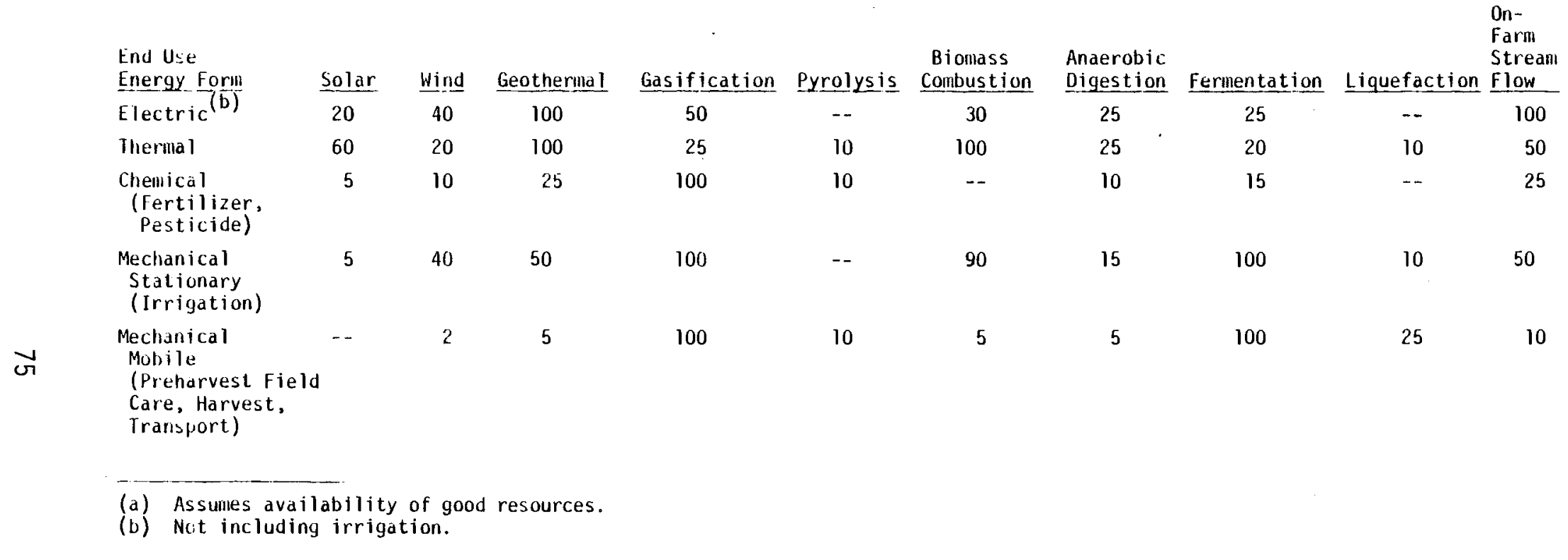




\section{,}


The success of federal involvement in the initiation of a program to induce energy independence in agriculture through energy-integrated farm systems is dependent on the existing use of energy, the availability of renewable energy resources and the state-of-the-art of conversion technology. The preceeding analysis identified 1) the current use of energy for agricultural production, 2) the resource availability, and 3) the conversion potential of renewable resources and technical opportunities. The purpose of this chapter is to establish the objectives of the program in terms of the level of farm energy independence that can be achieved by the year 2000 and to identify program guidelines to reach that objective. The guidelines are developed by integrating energy needs, resource availability and conversion technology potential to arrive at a projection of the energy that could be supplied by the substitution technologies.

The energy input by end use energy form for U.S. agriculture was discussed in Chapter 2 and is reviewed in Table 5.1. This table shows the annual (1978) energy input to both crop and livestock production. As previously discussed in Chapter 2, mechanical mobile energy and chemical energy have the highest energy demands.

An estimation of the energy that could be supplied by the substitution technologies is shown in Table 5.2. The numbers shown were obtained by multiplying the energy need (Table 5.1 ) by the average resource availability (Table 3.12) times the conversion potential (Table 4.2). Comparing the total energy that could be supplied for each end-use energy form shown in the right hand column of Table 5.2 and the energy needed (Table 5.1) shows that the substitution technologies do have the ability to make U.S. agriculture energy self-sufficient. Projections indicate that the substitution technologies could provide 4,425,920 billion Btu's for U.S. agriculture, compared to an energy demand of 2,027,596 billion Btu's. 
TABLE 5.1. Total Energy Input by End Use Energy Form for U.S. Crop and Livestock Production, 1978 (from Chapter 2)

End Use Energy Form

Mechanical Mobile

Mechanical Stationary

Therma1

Chemica 1

Electrical

Miscel1 1 aneous

Total
Billion Btu's

854876

277837

154206

720662

5783

14232

2027596 
TABLE 5.2. Energy That Could be Supplied by the Substitution Technology (Billion Btu's)

End Use

Energy

Form

Mechanical

Mobile

Mechanical

Stationary

Thermal

Chenical

Electrical

Total

Percent
Solar Wind Geothermal Gasification Pyrolysis Combustion

Anaerobic

Digestion

85,488

42,744

250,053

$13,892 \quad 4,445$

$92,524 \quad 1,234$

$36,033 \quad 2,883$

$1,157 \quad 93$

$143,606 \quad 9,339$

$3.2,0.2$

$\begin{array}{rrrr}855 & 854,876 & 85,488 & 42,744 \\ 2,778 & 277,837 & -- & 250,053 \\ 3,084 & 38,552 & 15,421 & 154,206 \\ 3,603 & 720,662 & 72,066 & -- \\ 117 & 2,892 & -- & 1,735 \\ 10,437 & 1,894,819 & 172,975 & 448,738 \\ 0.2 & 42.8 & 3.9 & 10.1\end{array}$

42,744

41,676

38,552

72,066

1,446

196,484

4.4

Fermetation

854,876

Low-

Head

Hydro

Total

277,837

30,841

108,099

1,446

$1,273,099$

28.8

\begin{tabular}{rrr} 
Liquefaction & $\begin{array}{l}\text { Low- } \\
\text { Head } \\
\text { Hydro }\end{array}$ & \multicolumn{1}{c}{ Total } \\
213,719 & 3,420 & $2,099,406$ \\
27,784 & 5,557 & 901,859 \\
15,421 & 3,084 & 392,919 \\
- & 7,207 & $1,022,619$ \\
- & 231 & 9,117 \\
256,924 & 19,499 & $4,425,920$ \\
5.8 & 0.4 &
\end{tabular}


Table 5.2 also provides a guideline as to which substitution technologies should be developed to make U.S. agriculture energy self-sufficient. The bottom row shows the energy that can be provided by each technology as a percentage of the total that all of the substitution technologies can provide. For example, fermentation is expected to be able to provide 28.8 percent of the energy provided by a 11 technologies and would therefore be expected to receive roughly 28.8 percent of the effort of the EIFS program. This analysis applies to each of the technologies and the approximate level of effort they should receive.

A regional analysis of the energy that could be supplied is given in Tables 5.3 through 5.10. Again, a comparison of the available supply shown in these tables with regional energy needs given in Chapter 2, indicates that U.S. agriculture can be energy self-sufficient on a regional basis. 
TABLE 5.3. Region 1 - Billion of Btu's that Could be Supplied by the Substitution Technologies (Based on 1974 Energy Needs)

\begin{tabular}{|c|c|c|c|c|c|c|c|c|c|c|}
\hline & Solar & Wind & Geothermal & Gasification & Pyrolysis & $\begin{array}{l}\text { Biomass } \\
\text { Combustion }\end{array}$ & $\begin{array}{l}\text { Anaerobic } \\
\text { Digestion }\end{array}$ & Fermentation & Liquefaction & $\begin{array}{l}\text { On- } \\
\text { Farm } \\
\text { Strea!n } \\
\text { Flow } \\
\end{array}$ \\
\hline $\begin{array}{l}\text { Electric } \\
\text { OVHS }\end{array}$ & 110 & -- & -- & 275 & -- & 165 & 138 & 138 & -- & 66 \\
\hline $\begin{array}{l}\text { Thermal } \\
\text { (Frost } \\
\text { Protection } \\
\text { Crop Drying) }\end{array}$ & 15,726 & -. & -. & 6,552 & 2,621 & ו1ו & 6,552 & 5,242 & 2,621 & 1,703 \\
\hline $\begin{array}{l}\text { Chemical } \\
\text { (Fertilizer, } \\
\text { Pesticide) }\end{array}$ & 4,186 & - & -. & 83,729 & 8,373 & -- & 8,373 & 12,599 & -- & 2,721 \\
\hline $\begin{array}{l}\text { Mechanical } \\
\text { Stationary } \\
\text { (Irrigation) }\end{array}$ & 76 & - & -- & 1,529 & -- & 1,376 & 229 & 1,529 & 153 & 99 \\
\hline $\begin{array}{l}\text { Mechanical } \\
\text { Mobile } \\
\text { (Preharvest } \\
\text { Field, Care } \\
\text { llarvest, } \\
\text { Transport) }\end{array}$ & -. & -. & -. & 73,510 & 7,351 & 3,676 & 3,676 & 73,510 & 18,377 & 955 \\
\hline Total & 20,098 & -- & -- & 165,595 & 18,345 & 31,428 & 18,968 & 92,978 & 21.151 & 5,544 \\
\hline
\end{tabular}


TABLE 5.4. Region 2 - Billions of Btu's that Could be Supplied by the Substitution Technologies (Based on 1974 Energy Needs)

\begin{tabular}{|c|c|c|c|c|c|c|c|c|c|c|}
\hline & Solar & Wind & Geotherina I & Gasification & Pyrolysis & $\begin{array}{c}\text { Bionass } \\
\text { Combustion } \\
\end{array}$ & $\begin{array}{l}\text { Anaerobic } \\
\text { Digestion }\end{array}$ & Fermentation & Liquefaction & $\begin{array}{l}\text { On- } \\
\text { Farm } \\
\text { Steam } \\
\text { Flow } \\
\end{array}$ \\
\hline $\begin{array}{l}\text { Electric } \\
\text { ovis }\end{array}$ & 110 & -- & -- & 276 & -- & 166 & 138 & 138 & -- & 11 \\
\hline $\begin{array}{l}\text { Therulal } \\
\text { (Frost } \\
\text { Protection } \\
\text { Crop } \\
\text { Drying) }\end{array}$ & 22,504 & - & -- & 9,377 & 3,751 & 37,508 & 9,377 & 7,501 & 3,751 & 375 \\
\hline $\begin{array}{l}\text { Chemical } \\
\text { (liertilizer } \\
\text { Pesticide) }\end{array}$ & 4,721 & - & -- & 94,426 & 9,443 & -- & 9,443 & 14,164 & -- & 472 \\
\hline $\begin{array}{l}\text { Mechanical } \\
\text { Stationary } \\
\text { (Irrigation) }\end{array}$ & 657 & - & - & 13,142 & -- & 11,828 & 1,971 & 13,142 & 1,314 & 131 \\
\hline $\begin{array}{l}\text { Mechanical } \\
\text { Mobile } \\
\text { (Preharvest } \\
\text { Field } \\
\text { Care, } \\
\text { Harvest, } \\
\text { Transport) }\end{array}$ & $\cdots$ & -- & -- & 85,199 & 8,520 & 4,260 & 4,260 & 85,199 & 21,300 & 170 \\
\hline Total & 27,992 & - & -- & 202,420 & 21,714 & 53,762 & 25,189 & 120,144 & 26,365 & 1,159 \\
\hline
\end{tabular}


TABLE 5.5. Region 3 - Billions of Btu's that Could be Supplied by the Substitution Technologies (Based on 1974 Energy Needs)

\begin{tabular}{|c|c|c|c|c|c|c|c|c|c|c|c|}
\hline & & Solar & Wind & Geother!nal & Gasification & Pyrolysis & $\begin{array}{l}\text { Biomass } \\
\text { Combustion }\end{array}$ & $\begin{array}{l}\text { Anaerobic } \\
\text { Digestion }\end{array}$ & Fermentation & Liquefaction & $\begin{array}{l}\text { On- } \\
\text { Farmi } \\
\text { Steam } \\
\text { Flow }\end{array}$ \\
\hline & $\begin{array}{l}\text { Electric } \\
\text { OVHS }\end{array}$ & 287 & -- & -- & 718 & -- & 431 & 359 & 359 & -- & 43 \\
\hline & $\begin{array}{l}\text { Therual } \\
\text { (Frost } \\
\text { Protection } \\
\text { Crop Dying) }\end{array}$ & 19,516 & - & -- & 8,132 & 3,253 & 32,528 & 8,132 & 6,506 & 3,253 & 488 \\
\hline & $\begin{array}{l}\text { Chemical } \\
\text { (Fertilizer, } \\
\text { Pesticide) }\end{array}$ & 9,810 & $-\infty$ & -- & 196,201 & 19,620 & -- & 19,620 & 29,430 & -- & 1,472 \\
\hline \multirow[t]{3}{*}{$\stackrel{\infty}{\omega}$} & $\begin{array}{l}\text { Mechanical } \\
\text { Stationary } \\
\text { (Irrigation) }\end{array}$ & 48 & -- & -- & 958 & -- & 862 & 144 & 958 & 96 & 14 \\
\hline & $\begin{array}{l}\text { Mechanical } \\
\text { Mobile } \\
\text { (Preharvest } \\
\text { Field } \\
\text { Care, Harvest, } \\
\text { Transport) }\end{array}$ & -- & - & -- & 166,146 & 16,615 & 8,308 & 8,308 & 166,146 & 41,537 & 498 \\
\hline & Total & 29,661 & -- & -- & 436,114 & 63,959 & 42.129 & 36,563 & 203,399 & 44,886 & 2,515 \\
\hline
\end{tabular}


TABLE 5.6. Region 4 - Billions of Btu's that Could be Supplied by the Substitution Technologies (Based on 1974 Energy Needs)

Solar Wind Geothermal Gasification Pyrolysis Combustion Digestion Fermentation Liquefaction flow

\begin{tabular}{|c|c|c|c|c|c|c|c|c|c|c|}
\hline $\begin{array}{l}\text { Electric } \\
\text { OVHS }\end{array}$ & 127 & -- & -- & 317 & -- & 190 & 158 & 158 & -- & 25 \\
\hline $\begin{array}{l}\text { Therimal } \\
\text { (Frost } \\
\text { Protection } \\
\text { Crop } \\
\text { Dying) }\end{array}$ & 5,408 & -- & - & 2,254 & 901 & 9,014 & 2,254 & 1,802 & 901 & 180 \\
\hline $\begin{array}{l}\text { Chemical } \\
\text { (Fertflizer, } \\
\text { Pesticide) }\end{array}$ & 3,510 & - & -- & 70,199 & 7,020 & -- & 7,020 & 10,530 & -- & 702 \\
\hline $\begin{array}{l}\text { Hechanical } \\
\text { Stationary } \\
\text { (Ir- } \\
\text { rigation) }\end{array}$ & 53 & -. & -- & 1,054 & -- & 949 & 158 & 1,054 & 105 & 21 \\
\hline $\begin{array}{l}\text { Mechanical } \\
\text { Mobile } \\
\text { (Preharvest } \\
\text { Field Care, } \\
\text { Harvest, } \\
\text { Transport) }\end{array}$ & - & -- & - & 80,662 & 8,066 & 4,033 & 4,033 & 80,622 & 20,166 & 333 \\
\hline Total & 9,098 & -. & - & 154,486 & 15,987 & 14,186 & 13,623 & 94,206 & 21,172 & 1,251 \\
\hline
\end{tabular}


TABLE 5.7. Region 5 - Billions of Btu's that Could be Supplied by Substitutions Technologies (Based on 1974 Energy Needs)

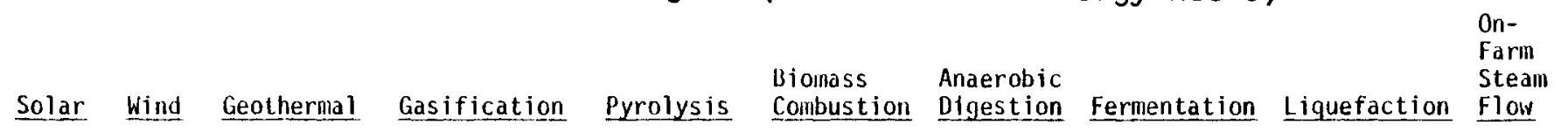

\begin{tabular}{|c|c|c|c|c|c|c|c|c|c|c|}
\hline $\begin{array}{l}\text { Electric } \\
\text { OVHS }\end{array}$ & 258 & 129 & -- & 646 & -- & 387 & 323 & 323 & - & 13 \\
\hline $\begin{array}{l}\text { Thermal } \\
\text { (Frost } \\
\text { Protection } \\
\text { Crop }\end{array}$ & & & & & & & & & & \\
\hline Drying) & 10,568 & 353 & -- & 4,403 & 1,761 & 17,613 & 4,403 & 3,523 & 1,761 & 88 \\
\hline $\begin{array}{l}\text { Chemical } \\
\text { (Fertilizer, } \\
\text { Pesticide) }\end{array}$ & 4,897 & 980 & $-\infty$ & 97,955 & 9,796 & - & 9,796 & 14,693 & -- & 245 \\
\hline $\begin{array}{l}\text { Mechanical } \\
\text { Stationary } \\
\text { (Irrigation) }\end{array}$ & 2,828 & 2,828 & -- & 56,544 & -- & 50,899 & 8,483 & 56,554 & 5,655 & 283 \\
\hline $\begin{array}{l}\text { Mechanical } \\
\text { Mobile } \\
\text { (Preharvest } \\
\text { Field } \\
\text { Care, } \\
\text { Harvest, } \\
\text { Transport) }\end{array}$ & - & 23 & -- & 10,990 & 5,495 & 5,495 & 5,495 & 109,903 & 27,476 & 110 \\
\hline
\end{tabular}


TABLE 5.8. Region 6 - Billions of Btu's that Could be Supplied by the Substitution Technologies (Based on 1974 Energy Needs)

\begin{tabular}{|c|c|c|c|c|c|c|c|c|c|c|}
\hline & Solar & Wind & Geothermal & Gasification & Pyrolysis & $\begin{array}{l}\text { Biomass } \\
\text { Combustion }\end{array}$ & $\begin{array}{l}\text { Anaerobic } \\
\text { Digestion }\end{array}$ & Ferimentation & Liquefaction & $\begin{array}{l}\text { On- } \\
\text { Farm } \\
\text { Stream } \\
\text { Flow }\end{array}$ \\
\hline $\begin{array}{l}\text { Electric } \\
\text { OVHS }\end{array}$ & 119 & 24 & -- & 297 & -- & 178 & 148 & 148 & -- & 11 \\
\hline $\begin{array}{l}\text { Therma 1 } \\
\text { (Frost Pro- } \\
\text { tection } \\
\text { Crop Dry- } \\
\text { ing) }\end{array}$ & 2,976 & 99 & -- & 1,242 & 497 & 4,966 & 1,242 & 993 & 497 & 50 \\
\hline $\begin{array}{l}\text { Chemical } \\
\text { (Fertilizer, } \\
\text { Pesticide) }\end{array}$ & 3,969 & 794 & $-\cdots$ & 79,372 & 7,937 & -- & 7,937 & 11,906 & -- & 397 \\
\hline $\begin{array}{l}\text { Mechanical } \\
\text { Stationary } \\
\text { (Irri- } \\
\text { gation) }\end{array}$ & 4,294 & 4,294 & -- & 85,889 & -- & 77,300 & 12,883 & 85,889 & 8,589 & 859 \\
\hline $\begin{array}{l}\text { Mechanical } \\
\text { Mobile } \\
\text { (Preharvest } \\
\text { Field Care. } \\
\text { Harvest, } \\
\text { Transport) }\end{array}$ & -- & 273 & -- & 61,400 & 6,140 & 3,070 & 3,070 & 61,400 & 15,350 & 123 \\
\hline Total & 11,358 & 5,383 & -- & 228,200 & 14,574 & 85,514 & 25,280 & 160,336 & 14.436 & 1,440 \\
\hline
\end{tabular}


TABLE 5.9. Region 7 - Billions of Btu's that Could be Supplied by the Substitution Technologies (Based on 1974 Energy Needs)

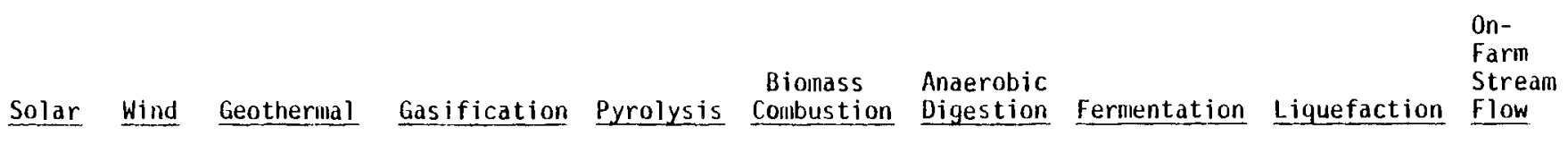

\begin{tabular}{|c|c|c|c|c|c|c|c|c|c|c|}
\hline $\begin{array}{l}\text { Electric } \\
\text { OVHS }\end{array}$ & 67 & 13 & 33 & 166 & -- & 100 & 83 & 83 & -- & 30 \\
\hline $\begin{array}{l}\text { Therulal } \\
\text { (Frost Pro- } \\
\text { tection } \\
\text { Crop Dry- } \\
\text { iny) }\end{array}$ & 10,684 & 356 & 1,781 & 4,452 & 1,781 & 17,807 & 4,452 & 3,561 & 1,781 & 801 \\
\hline $\begin{array}{l}\text { Chemical } \\
\text { (Fertilizer } \\
\text { Pesticide) }\end{array}$ & 2,945 & 589 & 1,472 & 58,906 & 5,891 & -- & 5,891 & 8,836 & -- & 1,325 \\
\hline $\begin{array}{l}\text { Mechanical } \\
\text { Stationary } \\
\text { (Irri- } \\
\text { gation) }\end{array}$ & 2,866 & 2,866 & 2,866 & 57,314 & $\cdots$ & 51,583 & 8,597 & 57,314 & 5,731 & 2,579 \\
\hline $\begin{array}{l}\text { Mechianical } \\
\text { Mobile } \\
\text { (Preharvest } \\
\text { Field Care, } \\
\text { llarvest, } \\
\text { Transport) }\end{array}$ & $\cdots$ & 95 & 237 & 47,340 & 4,734 & 2,367 & 2,367 & 47,340 & 11,835 & 426 \\
\hline Total & 16,562 & 3,919 & 6,389 & 168,178 & 12,406 & 71,857 & 21,390 & 117,134 & 19,347 & 5,161 \\
\hline
\end{tabular}


TABLE 5.10. Region 8 - Billions of Btu's that Could be Supplied by the Substitution Technologies (Based on 1974 Energy Needs)

\begin{tabular}{|c|c|c|c|c|c|c|c|c|c|c|}
\hline & Solar & Wind & Geothermal & Gasification & Pyrolysis & $\begin{array}{l}\text { Biomass } \\
\text { Combustion }\end{array}$ & $\begin{array}{l}\text { Anaerobic } \\
\text { Digestion }\end{array}$ & Fermentation & Liquefaction & $\begin{array}{l}\text { On- } \\
\text { Farm } \\
\text { Stream } \\
\text { Flow } \\
\end{array}$ \\
\hline $\begin{array}{l}\text { Electric } \\
\text { OVHS }\end{array}$ & 85 & -- & 25 & 212 & -- & 127 & 106 & 106 & -- & 25 \\
\hline $\begin{array}{l}\text { Thermal } \\
\text { (Frost } \\
\text { Protection } \\
\text { Crop Dry- } \\
\text { ing) }\end{array}$ & 1.615 & -- & 239 & 598 & 239 & 2,392 & 598 & 478 & 239 & 72 \\
\hline $\begin{array}{l}\text { Chemical } \\
\text { (Ferti- } \\
\text { lizer, } \\
\text { Pesticide) }\end{array}$ & 1,680 & -- & 840 & 33,595 & 3,359 & -- & 3,350 & 5,039 & $\cdots$ & 504 \\
\hline $\begin{array}{l}\text { Mechanical } \\
\text { Stationary } \\
\text { (Irri- } \\
\text { gation) }\end{array}$ & 2,092 & -. & 2,092 & 41,844 & -- & 37,660 & 6,277 & 41,844 & 4,184 & 1,255 \\
\hline $\begin{array}{l}\text { Mechanical } \\
\text { Mobile } \\
\text { (Preliarvest } \\
\text { Field Care, } \\
\text { llarvest, } \\
\text { Transport) }\end{array}$ & -- & -- & 1,754 & 35,077 & 3,508 & 1,754 & 1,754 & 35,077 & 8,769 & 210 \\
\hline Total & 5,472 & -- & 4,950 & 111,326 & 7,106 & 41,933 & 12,094 & 82,544 & 13,192 & 2,066 \\
\hline
\end{tabular}


CHAPTER 6

ACCEPTABILITY OF INTEGRATED FARM SYSTEMS TO OWNERS/USERS AND INSTALLATION AND MAINTENANCE PERSONNEL

Every commercial farmer in America works under a capital budget constraint. The impact of an Energy Integrated Farm System Program is predicated on technological acceptability within capital budget constraints. The previous chapters have discussed the development and potential of the EIFS program in technical terms and on an objective basis. This chapter addresses some of the factors affecting the subjective attitudes toward energy-integrated farm systems. The purpose of this chapter is to bring the insights and findings of the preceding chapters into perspective of a "bench mark" farm in each of the eight regions. This analysis is particularly important for those technologies that would be implemented on an individual farm scale.

Two factors affect acceptability: 1) the scale of use, and 2) the attitudes of those who will own/use the equipment and those who will install and maintain the energy-integrated farm systems. The scale of use involves the relative size of the EIFS compared to the normal scale of farm operations. The attitudes of the key players help determine whether anyone will be interested in selling, financing, installing, maintaining or finally using the EIFS.

Accordingly, the first point of this chapter will address indirectly the problem of appropriateness of scale of the technology by looking at typical farms in the various regions. Qeustions concerning whether a farm needs 50 gal of gas a year or 5,000 gal will be addressed. It makes a great deal of difference to the design, installation, operation and maintenance of the equipment.

In the second part of this chapter some of the viewpoints to be considered in attempting to determine acceptability of concepts for integrated farm systems will be briefly assessed. 


\subsection{SCALE OF EIFS USE}

The scale of energy use on farms is expected to be an important consideration in the acceptability of energy integrated farm systems. This question is examined with the aid of example farms. The process we have used is to characterize average size farms in each of the eight regions (see Tables 6.1 - 6.6 for data about average farms). The farms range in size from 160 acres in the northeast to about 2,500 acres in the mountain west. Next model farms were assembled, each planted entirely with one of the eight major crops. Thus, each region potentially has eight farms. These are included in Appendix $B$ where the energy needs of these farms are shown for gasoline, diesel, liquefied Petroleum Gas (LPG), natural gas, electricity, fertilizer, chemicals, etc.

From these we have carefully selected eight farms, one for each of the regions, that give a reasonable representation of American agriculture. The energy consumption of these eight farms is shown in Table 6.7. To further aid in recognizing what's involved and aid the reader in visualizing the scales involved, they are shown in conventional quantities such as gallons of gasoline, diesel, and LPG; cubic feet of natural gas; and kilowatt hours of electricity in Table 6.8.

Other types of farms exist, including dairies, orchards, and produce farms, etc. These farms have not been characterized although they would account for nearly $20 \%$ of agriculture. Dairies are particularly appropriate for consideration because of the unique opportunities for using biomass made available continuously. Therefore, Table 6.9 includes a characterization of an "average" dairy.

In the following section the scale of requirements is reviewed for each energy type for the major crops.

\subsubsection{Where Energy Containing Materials are Needed}

\subsubsection{Gasoline}

Gasoline use is universal to each farm studied and its use varies from two gal/day (i.e., $600 \mathrm{gal} / \mathrm{yr}$ ) on a 220-acre farm raising corn in 
TABLE 6.1. General Characterization of U.S. Farms

Total number of farms (1978)

$$
\begin{array}{r}
2,680,150 \\
1,072,333,000 \\
41,243,000 \\
400.1
\end{array}
$$

Total acres (1978)

Irrigated acres (1974)

Average acres per farm

\begin{tabular}{|c|c|c|c|}
\hline & $\$ /$ Acre & Average Size (Acres) & Average \$/Farm \\
\hline $\begin{array}{l}\text { U.S. } \\
\text { Region }\end{array}$ & 488.76 & 400.1 & 195,553 \\
\hline 1 & 752.00 & 159 & 119,568 \\
\hline 2 & 582.00 & 244 & 142,008 \\
\hline 3 & $1,174.00$ & 219 & 257,106 \\
\hline 4 & 741.00 & 206 & 152,646 \\
\hline 5 & 319.00 & 852 & 271,788 \\
\hline 6 & 334.00 & 571 & 190,714 \\
\hline 7 & 173.00 & 2,570 & 446,610 \\
\hline 8 & 430.00 & 1,907 & 820,010 \\
\hline
\end{tabular}

Total value of farmland and buildings $\$ 523,952,000,000$

Source: U.S. Department of Agriculture 1980.

TABLE 6.2. Average Value of Farmland and Buildings by Region

Source: U.S. Department of Agriculture 1980. 
TABLE 6.3. Average Value of Machinery, Motor Vehicles and Livestock

Value of machinery and motor vehicles

Average value of machinery and motor vehicles per farm

Value of livestock

Average value of livestock per farm
$\$ 77,300,000,000$

$\$$

28,842

$\$ 32,000,000,000$

$\$$

11,940

Source: U.S. Department of Agriculture 1980.

TABLE 6.4. Land Utilization of U.S. Farmland

$\%$ of Total Acreage

Cropland

Used for crops

Idle

Used of Pasture

34

2

Grassiand Pasture

56

Source: U.S. Department of Agriculture 1980.

TABLE 6.5. Characterization of U.S. Farm Population (1977)

Total farm population

Average population per farm

Total hired workers

Average hired workers per farm
$7,806,000$ people

2.88

$1,295,900$

0.48

Source: U.S. Department of Agriculture 1980. 
TABLE 6.6. Livestock by Type on U.S. Farms

Cattle
Hogs
A11 Sheep
Chickens
Turkey breeder hens

Thousands of Head

116,265

56,656

12,387

386,531

3,045

Source: U.S. Department of Agriculture 1980. 
TABLE 6.7. Energy in Millons of Btu for Various Farm Needs for Example Farms in Each Region

\begin{tabular}{|c|c|c|c|c|c|c|c|c|}
\hline Crop (Acres) & $\begin{array}{l}\text { Region } 1 \\
\text { Hay (160) }\end{array}$ & $\begin{array}{c}\text { Region } 2 \\
\text { Soybeans }(240)\end{array}$ & $\begin{array}{l}\text { Region } 3 \\
\text { Corn } \\
\text { Grain }(220) \\
\end{array}$ & $\begin{array}{l}\text { Region } 4 \\
\text { Corn } \\
\text { Silage }(200)\end{array}$ & $\begin{array}{l}\text { Region } 5 \\
\text { Sorghuin }(570)\end{array}$ & $\begin{array}{l}\text { Region } 6 \\
\text { Cotton }(570) \\
\end{array}$ & $\begin{array}{l}\text { Regi on } 7 \\
\text { Wheat }(2500)\end{array}$ & $\begin{array}{l}\text { Region } 8 \\
\text { Hay (1900) }\end{array}$ \\
\hline Gasoline & 92 & 328 & 76 & 287 & 653 & 275 & 1920 & 1322 \\
\hline Diesel & 5 & 435 & 258 & 189 & 872 & 563 & 1323 & 397 \\
\hline$\angle P G$ & 14 & 34 & 297 & 122 & 225 & 87 & 149 & 158 \\
\hline Natural Gas & 6 & 13 & 17 & 2 & 663 & 993 & 396 & 2859 \\
\hline Electricity & 2 & 8 & 14 & 8 & 55 & 77 & 360 & 6604 \\
\hline Fertilizers & 421 & 113 & 904 & 650 & 1573 & 750 & 2230 & 320 \\
\hline Chemicals & $=-$ & 63 & -56 & $\underline{53}$ & 129 & $\underline{2359}$ & 33 & $\underline{0}$ \\
\hline Totals & 540 & 995 & 1622 & 1311 & 4170 & 5104 & 6411 & 11660 \\
\hline
\end{tabular}




\section{TABLE 6.8. Quantities of Various Energy Containing Materials Needed}

on Example Farms in Each Region

\begin{tabular}{|c|c|c|c|c|c|c|c|c|}
\hline Crop (Acres) & $\begin{array}{l}\text { Region } 1 \\
\text { Hay }(160)\end{array}$ & $\begin{array}{c}\text { Region } 2 \\
\text { Soybeans }(240)\end{array}$ & $\begin{array}{c}\text { Region } 3 \\
\text { Corn } \\
\text { Gain }(220)\end{array}$ & $\begin{array}{l}\text { Region } 4 \\
\text { Corn } \\
\text { Silage }(200)\end{array}$ & $\begin{array}{c}\text { Region } 5 \\
\text { Sorghum } \\
\text { Grain }(850)\end{array}$ & $\begin{array}{c}\text { Region } 6 \\
\text { Cotton }(570)\end{array}$ & $\begin{array}{c}\text { Region } 7 \\
\text { Wheat }(2500)\end{array}$ & $\begin{array}{l}\text { Region } 8 \\
\text { Hay }(1900)\end{array}$ \\
\hline $\begin{array}{l}\text { Gasoline } \\
\text { (gal/yr) }\end{array}$ & 736 & 2624 & 608 & 2296 & 5225 & 2200 & 15360 & 10576 \\
\hline $\begin{array}{l}\text { Diesel } \\
\text { (gal/yr) }\end{array}$ & 36 & 3100 & 1800 & 1400 & 6200 & 4000 & 9400 & 2800 \\
\hline LPG (gal/yr) & 150 & 350 & 2100 & 1300 & 2400 & 900 & 1500 & 1650 \\
\hline $\begin{array}{l}\text { Natural Gas } \\
\left(1000 \mathrm{ft}^{3} / \mathrm{yr}\right)\end{array}$ & 5 & 13 & 16 & 1 & 620 & 920 & 370 & 2700 \\
\hline $\begin{array}{l}\text { Electricity } \\
\left(\mathrm{kWh} / \mathrm{yr}^{\prime}\right)\end{array}$ & 590 & 2300 & 4100 & 2300 & 16100 & 23000 & 105000 & $1.93 \times 10^{6}$ \\
\hline $\begin{array}{l}\text { Fertilizer } \\
\text { tons/yr }\end{array}$ & 12.4 & 3.3 & 26.6 & 19.1 & 46.3 & 22 & 65.6 & 57.8 \\
\hline $\begin{array}{l}\text { Pesticides } \\
\text { etc., tons/yr }\end{array}$ & & 0.27 & 0.24 & 0.23 & 0.56 & 10.2 & 0.14 &.-- \\
\hline
\end{tabular}


TABLE 6.9. Average Energy Used in Milk Production (a)

\begin{tabular}{|c|c|c|c|}
\hline & $\begin{array}{l}\text { Average Energy in } \\
\text { Thousands Btu's } \\
\text { per Head }(a)\end{array}$ & $\begin{array}{l}\text { Average Energy per } \\
\text { Farm in Millions } \\
\text { of Btu's (b) } \\
\end{array}$ & $\begin{array}{l}\text { Units of } \\
\text { Energy }\end{array}$ \\
\hline Gasoline & 2392 & 185 & 1480 ga 1 \\
\hline Diese 1 & 0 & 0 & --- \\
\hline LPG & 661 & 51 & 534 ga 1 \\
\hline Natural Gas & 0 & 0 & --- \\
\hline Electricity & 1530 & 118 & $34574 \mathrm{kWh}$ \\
\hline Total & 4583 & 354 & \\
\hline
\end{tabular}

Source: U.S. Department of Agriculture 1976.

(a) For average herd size, which is 77.3 cows in the U.S. (USDA Agricultural Statistics 1978) 
the midwest, or a 160-acre hay farm in the northeast, to about 42 gal/day or 15,000 gal/yr on a 2,500-acre wheat farm in the mountain west. The most striking conclusion is that supplying the gasoline fuels would span more than an order of magnitude in capacity just for the farms included in the eight example farms summarized in Table 6.8 .

\subsubsection{Diesel}

Diesel is not universally used on all farms and in particular is used less on small farms and for equipment having light or intermittent duty. In the example farms, diesel usage varied from $1,400 \mathrm{ga} 1 / \mathrm{yr}$ for a 200-acre farm growing corn silage to 9,400 gal/yr on a 2,500 acre wheat farm. This usage calculates to be about 4 to $25 \mathrm{gal} /$ day.

\subsubsection{Liquefied Petroleum Gas (LPG)}

Liquefied petroleum gas use varies from $150 \mathrm{gal} / \mathrm{yr}$ to $2,400 \mathrm{gal} / \mathrm{yr}$ and its use ranges from around 2 gal/day or less to $5 \mathrm{gal} /$ day (see Table 6.8). Again the range varies over more than an order of magnitude. Replacing LPG would require a wide range of ratings for the appropriate energy technologies.

\subsubsection{Natural Gas}

Natural gas use has been very modest on U.S. farms as the example farms reflect, possibly because farmers never had a "national farm gasification administration" to help with the costs of a distributing network covering the farm areas. Natura 1 gas shows up in Regions 6 and 8 where it is extensively used to pump irrigation water and in processing agricultural products.

Replacing the natural gas use (in internal combustion engines) with a biomass gasifier would be more exacting than replacing it in thermal (heating) applications. Using it to replace all the pumping energy on a 2,000-acre hay farm would require about $10 \mathrm{million} \mathrm{ft}^{3}$ and on some other farms somewhat less. Gasifiers would have to span more than an order of magnitude in ratings to cover the market needs. These ratings would cover 
a range from about $1 \mathrm{million} \mathrm{ft}^{3} /$ day to about $30,000 \mathrm{ft}^{3} /$ day. With this range of gasifiers, the needs of many farms that use only a little natural gas for incidental heating needs would still not be met.

\subsubsection{Electricity}

The use of electricity on farms is almost universal but varies from $590 \mathrm{kWh} / \mathrm{yr}$ on a small hay farm in the northeast to about $3 \mathrm{million} \mathrm{kWh} / \mathrm{yr}$ on a 1,900-acre western hay farm that uses electricity primarily to pump irrigation water. The uses are legion and the applications vary from those absolutely requiring electricity to those that could easily be substituted by other energy forms.

Some of the largest uses, such as irrigation, could be replaced by another motive source. For example, if 3 million $\mathrm{kWh}$ would be used in about $3,000 \mathrm{hr} / \mathrm{yr}$, approximately $1,000 \mathrm{hp}$ of prime mover would be needed on a 1,900-acre hay farm.

\subsubsection{Fertilizers}

Fertilizers are almost universally applied in U.S. farming. The use of nitrogenous fertilizers is dramatically less on those farms raising legume crops: beans, peas, soybeans, and alfalfa hay.

The total fertilizer energy is about 10\% (on a farm growing legume crops) of what would be required for a farm growing conventional crops, which deplete the nitrogen content of the soil. The fertilizer energy requirements are as low as $113 \mathrm{million}$ Btu/yr for a soybean farm (240 acres) compared to 2,230 million Btu's of fertilizer energy for a 2,500acre wheat farm. In Table 6.8 this represents a 3 to 65 tons/yr range.

Since crop rotation is practiced on many farms and the rotation system includes legume crops, the fertilizer requirements would be expected to vary dramatically from year to year. These fertilizer energy figures do not include the normal practice of recycling farm wastes and byproducts to the soil. Production of nitrogenous fertilizers on the farm would be more attractive for those farms where heavy fertilization is absolutely required and crop rotation is impractical or 
uneconomical, resulting in a stable year to year need. Some farms have been operated with vastly reduced input of imported (i.e., brought onto the farm) fertilizer (Lockeretz, et a1. 1975). Lockeretz (1975) compares economic returns and energy consumption for corn belt farms that use inorganic fertilizers and pesticides with corn belt farms that use "organic" fertilizers. The "organic" farms used about one-third of the energy used by conventional farms. The standard of comparison for suggested systems that produce nitrogenous fertilizers on the farm may be the "organic farm."

\subsubsection{Pesticides}

The energy requirements to produce pesticides is quite negligible on many of the example farms. The standout exception is the Region 6 cotton farm, where half of the total farm energy is for chemicals used for herbicides and insecticides. This 570-acre farm used 50 times more energy for pesticides than most of the example farms. Recent developments indicate that this situation may change drasticaliy since most pests are becoming resistant to a broad range of chemical control agents. In any case, chemical production for on-the-farm use appears to be somewhat remote.

\subsection{THE ATTITUDES OF THOSE WHO OWN, USE, INSTALL AND MAINTAIN THE EIFS}

Attention is often focused on particular aspects of the commercial chain involved in manufacturing, installing, using and finally maintaining various conversion technologies. An overview of the needs of the partipants in this process is presented in the following paragraphs and an overall focus pinpointing some potential issues is established. A simplified version of the commercial chain involves manufacturers, financiers, distributors and tradesmen, users/owners, and of course, a number of others (who have been omitted for clarity).

The reactions of some potential market participants to the various candidate EIFS are estimated by PNL staff in Table 6.10. Severar key issues are identified: 
TABLE 6.10. Estimated Reaction of Market Participants to Candidate EIFS Technologies

\begin{tabular}{|c|c|c|c|c|c|}
\hline & Solar & Wind & Geotherinal & Low-llead Hydro & Biomass \\
\hline Manufacturers & $\begin{array}{l}\text { Could make } \\
\text { solar } \\
\text { packages }\end{array}$ & $\begin{array}{l}\text { Could make } \\
\text { wind } \\
\text { machines }\end{array}$ & $\begin{array}{l}\text { Architect/engine- } \\
\text { ering firms could } \\
\text { design a system }\end{array}$ & $\begin{array}{l}\text { Architect/engineering } \\
\text { firms could design a } \\
\text { system }\end{array}$ & $\begin{array}{l}\text { Architect/engineering } \\
\text { firms could design a } \\
\text { system }\end{array}$ \\
\hline Financers & $\begin{array}{l}\text { Could loan } \\
\text { money, but } \\
\text { are cautious }\end{array}$ & $\begin{array}{l}\text { Could loan } \\
\text { money, but } \\
\text { are cautious }\end{array}$ & $\begin{array}{l}\text { Will require other } \\
\text { collateral }\end{array}$ & $\begin{array}{l}\text { Will require other } \\
\text { collateral }\end{array}$ & $\begin{array}{l}\text { Will require other } \\
\text { collateral }\end{array}$ \\
\hline Distributors & $\begin{array}{l}\text { Could handle, } \\
\text { will probably } \\
\text { "try a few" }\end{array}$ & $\begin{array}{l}\text { Could handle, } \\
\text { will probably } \\
\text { "try a few" }\end{array}$ & $\begin{array}{l}\text { Can stock parts if } \\
\text { enough systems in }\end{array}$ & $\begin{array}{l}\text { Can stock parts if } \\
\text { enough systems in }\end{array}$ & $\begin{array}{l}\text { Can stock parts if enough } \\
\text { systerns are installed }\end{array}$ \\
\hline Tradesmen & $\begin{array}{l}\text { Can install } \\
\text { won't appre- } \\
\text { ciate "call } \\
\text { backs" }\end{array}$ & $\begin{array}{l}\text { Can install } \\
\text { won't appre- } \\
\text { ciate "call } \\
\text { backs" }\end{array}$ & $\begin{array}{l}\text { Iristalled by con- } \\
\text { struction crew }\end{array}$ & $\begin{array}{l}\text { Installed by con- } \\
\text { struction crew }\end{array}$ & $\begin{array}{l}\text { Installed by construction } \\
\text { crew }\end{array}$ \\
\hline Users/Owners & $\begin{array}{l}\text { Will intially } \\
\text { tolerate } \\
\text { tinkering, but } \\
\text { will demand } \\
\text { reliable } \\
\text { trouble-free } \\
\text { long term }\end{array}$ & $\begin{array}{l}\text { Will ini- } \\
\text { tially } \\
\text { tinkering, } \\
\text { but will } \\
\text { demand } \\
\text { reliable } \\
\text { trouble-free } \\
\text { long tern }\end{array}$ & $\begin{array}{l}\text { Will require con- } \\
\text { tinued preventive } \\
\text { maintenance }\end{array}$ & $\begin{array}{l}\text { Will require seasonal } \\
\text { supervision and } \\
\text { maintenance }\end{array}$ & $\begin{array}{l}\text { Will require continuous } \\
\text { feeding removal and } \\
\text { preventative ma intenance }\end{array}$ \\
\hline
\end{tabular}


- A11 of the EIFS systems will have a strong tendency to be unique; getting them reduced to nice packaged products will be difficult. Solar and wind look a little closer to a product line right now.

- Financiers are going to want "a good reputation" or some tangible collateral for EIFS loans in addition to the EIFS itself.

- Distributors will have a very hard time with diversity of designs and concepts. They will "try a few" but won't plunge. Distribution will be a difficult problem and may leave farmers dealing "with the factory."

- The tradesman will have a hard time with diversity of designs and the spread of their territory. As a result, relationships with farmers may be strained.

- Users/owners. A major reason why farmers readily abandoned many old technologies, such as biomass operated threshing machines, was because the machines needed to be continuously fed or tended.

- The economics, of course, also turned toward other approaches - but the newer approaches also supplied convenience and dependability. Convenience and dependability will ultimately spell the difference between those EIFS successful concepts and unsuccessful concepts.

These comments don't represent a basis for discriminating among these concepts at this time, but they should be considered as specific designs are evaluated.

\subsection{SUMMARY OF THE TECHNOLOGICAL ACCEPTABILITY OF THE EIFS}

The key factor encountered in reviewing the scale of operation required for the various systems is that the needed scale varies by an order of magnitude or more. An industrial product planner will perceive that the concepts have to be suitable for modular use with little loss of efficiency, convenience, or economy--or a family of products sized for each major concept will be required.

The data in the appendices and Tables 6.7, 6.8, and 6.9 will be helpful in evaluating the suitability of various concepts in various 
applications. One product class, "chemicals," is seen as being generally unsuitable for on-farm production although they might be suitable for large cooperatives. The scales of use vary over orders of magnitude. On this basis there are likely to be many farms where the scale is eminently suitable for production of portable fuels. For many other uses EIFS technologies appear to have reasonable scale so that they could be applied even in situations where short term economics (i.e., costs) might favor a conventional energy source.

This chapter can be summarized by listing several questions that are raised regarding the energy technologies:

- Will the technology fill a niche between the extremes of being so small in scale that it doesn't displace a valuable commodity or get so large in scale as to jeopardize the other needs of the farm operation (time, capital, etc.)?

- Will the technology provide the energy where it is needed when it is needed?

- Will the technology ultimately meet the needs of the infrastructure of its widescale deployment?

These questions are not independent of Chapters 1, 2, 3, and 4 and may be used as a kind of overview of some of the key issues to be met in getting EIFS off to a good start. 


\section{REFERENCES}

Anschutz, J. A., R. I. Lipper. 1975. Electric Use of Dairies in in Kansas Paper presented to the Kansas Committee on the relation of Electricity to Agriculture, 1974-75 meeting.

Baughman, G. R. and C. R. Parkhurst. 1976. Energy Consumption in Broiler Production. Transactions of the ASAE. 20(2):

Bliss, C., and D. 0. Blake. 1977. Silviculture Biomass Farms: Volume $V$ - Conversion Processes and Costs. MTR-7347, Mitre Corporation, McLean, Virginia.

Brow, R. S., R. Napoli, A. S. Goodman and L. Thatcher. 1978. "Status of Smal1 Hydropower Studies in New York State." In Low-Head Hydro. Idaho Water Resources Research Institute, Moscow, Idaho.

Buswe11, A. M. and H. F. Mueller. 1952. "Mechanics of Methane Fermentation." Industrial and Engineering Chemistry, 44: 550-552.

Coffman, J. A., and R. H. Hooverman. 1978. "Power from Wastes via Steam Gasification." ACS Symposium Series 76. pp. 252-273.

Council for Agricultural Science and Technology. 1977. Energy Use in Agriculture: Now and for the Future. CAST Report No. 68, Iowa State University, Ames, Iowa.

David, M. L., G. S. Hammaker, R. J. Buzenburg and J. P. Wagner, "Gasohol Economic Feasibility Study," Development Planning and Research Associates Inc. P.0. Box 727, Manhatten, Kansas 66502, July 1978.

Dvoskin, Dan, and Earl 0. Heady. 1976. Energy Requirements of Irrigated Crops in the Western United States. Center for Agricultural and Rural Development, Iowa State University, Ames, Iowa.

Elliott, D. L. "Synthesis of National Wind Energy Assessment" PNL-2220, WIND-5, 1977.

Energy and U.S. Agriculture: 1974 and 1978. U.S. Department of Agriculture, Washington D.C., 1980.

Energy and U.S. Agriculture: 1974 Data Base. U.S. Department of Agriculture Washington, D.C., 1976.

Energy Research and Development Administration. 1977. Solar Energy for Agriculture and Industrial Process Heat, Program Summary. ERDA-77-72, Division of Solar Energy, Washington, D.C.

Falgenhauser, D. L., 1978, "The W.W.P. View" in Low-Head Hydro-An Examination of an Alternative Energy Source, by J. S. Gladwe 11, Idaho Water Resources 
Research Institute and C. C. Warmick, University of Idaho.

Frank, G. G. 1977. A Guide to Energy Savings for The Dairy Farmer. NTIS No. PR-270 076, Federal Energy Administration, Washington, D.C.

Friedrich, Robert A. 1978. Energy Conservation for American Agriculture. Environmenta 7 Law Institute State and Local Energy Conservation Project, Ballinger Publishing Company, Cambridge, Massachusetts.

Fritz, Jack J., et a1. 1978. Status Review of Wood Biomass Gasification, Pyrolysis and Pelletization Technologies. MTR-8031 (draft), Mitre Corporation McLean, Virginia.

Goodwin, et a7. USGS Circular 647.

Head, J. 1970. "Geothermal Energy for Greenhouse Heating." Ore Bin 32. Vol. 9, pp. 182-183.

"Inside DOE." October 5, 1979.

Kaufman, J. A., and A. H. Weiss. 1975. Solid Waste Conversion: Cellulose Liquefaction. National Environmental Research Center Report \#EPA-670/275-031.

Lee, G. K. "Energy Intensiveness of Washington Agriculture and the Effects of Increases in Energy Prices on Washington Agriculture," in Agriculture and Energy, Academic Press, 1977.

Lipper, R. I., J. A. Anschutz, J. C. Welker. 1976. Energy Requirements for Commercial Beef Cattle Feedlots in Kansas. Paper No. MC76-301, American Society of Agricultura7 Engineers, St. Joseph, Missouri.

Lockertz, W. 1977. Agriculture and Energy. Academic Press, New York, NY. Lockeretz, W., Klepper, R., Commoner, B., Gertler, M., Fast, S., O'Leary, D. and Blobaum, R. 1975. A Comparison of the Production, Economic Returns, and Energy Intensiveness of Corn Belt Farms that do and do Not Use Inorganic Fertilizers and Pesticides. PB-243 639. Ju1y 1975. Prepared for the National Science Foundation by Center for the Biology of Natural Systems, Washington University, St. Louis, Missouri.

Lomas, C. C., and M. J. Robinette. 1978. "Studying the Northwest Low-Head Hydro Potential." In Low-Head Hydro. Idaho Water Resources Research Institute, Moscow, Idaho.

Mansfield, E., J. Rapoport, A. Romeo, E. Villani, S. Wagner and F. Husic. 1977. The Production and Application of New Industrial Technology.

W. W. Norton and Company, Inc., New York, New York.

Meine1. 1977. Applied Solar Energy, Reading, Mass, Addison-Wesley Publ. Co., (1976) 
Mercer. 1978. "Very-Low-Head Hydroelectric Generation" in Low-Head Hydro-An Examination of an Alternative Energy Source, by J.S. Gladwe11, Idaho Water Resources Research Institute and C. C. Warmick, University of Idaho.

Mikese11, R. D., et a1. 1978. "A Thermal Process for Energy Recovery from Agricultural Residues." ACS Symposium Series 76, pp. 252-273.

Miles, T. R. 1975. "Consulting Engineers' Synopsis of Our Work" for the Oregon Field Sanitation Committee, December 5, 1976.

Miles, T. R., "Energies From the Field-USA," Presented to Sixth Annual Meeting, The Biomass Energy Institute, Winnipeg, Canada, 1977.

Moses, C. T., et a1. 1978. "Co-Disposal of Sludge and Refuse in a Purox Converter." ACS Symposium Series 76, pp. 63-87.

Muffler. 1979. USGS Circular 790.

NASA/ASEE Systems Design Institute. 1974. Energy Recovery from Solid Waste. Vol. 2 Technical Report, NGT 44-005-114, University of Houston.

Program Plan - Non-Electric Applicätions of Geothermal Heat. 1977. Department of Energy, Division of Geothermal Energy (draft).

Pytlinski, J. T. 1978. "Solar Energy Installations for Pumping Irrigation Water." Solar Energy. 21(4): 260-261.

Rex R., "U.S. Geothermal Industries in 1978", Geo Chemical Energy Vo1. 6, No. 7, July 1978.

Sealock, L. J., Jr., et a1. 1978. "Catalyzed Gasification of Biomass." Paper presented at the First World Conference on Future Sources of Organic Raw Materials, July 1978, Toronto, Canada.

Skov, Niels A., and M. L. Papworth. 1975. The Pegasus Unit. Pegasus Inc., P.0. Box 121, O1ympia, Washington.

Smith, R. J., J. A. Miranowski, R. L. Vetter. 1976. Energy Relationships for a 320-Acre Iowa Farm, An Attempt to Increase Production of Grain and Meat While Rendering the Farm Energy Self-Sufficient by Generating Methane Through Anaerobic Fermentation of Residues. NTIS no. PB-275 274 , Agricultural Research Service, Hyattsville, Maryland.

The Handbook of Homemade Power. 1974. The Mother Earth News, Hendersonville, North Carolina.

U.S. Department of Agriculture. Agricultural Statistics 1978. U.S. Government Printing Office, Stock No. 001-000-03775-7. 
U.S. Department of Energy. 1979. "Proposals for Energy Integrated Farm Systems, PON No. C501-79CS-40217.

U.S. Department of the Interior Geological Survey. 1970. The National Atlas of the United States of America. Washington, D.C.

USDA-Forest Service. 1976. The Feasibility of Utilizing Forest Residue for Energy and Chemicals. Report to the National Science Foundation and Federal Energy Administration, NSF-RA-7600/3.

Walden, 0. 1978. Prepared Testimony before the Senate Energy Committee, Washington, D.C.

Wealey, H. L., M. M. Orgi11 and R. L. Drake. 1978. A Siting Handbook for Small Wind Energy Conversion Systems. PNL-2521/WC-60. Pacific Northwest Laboratory, Richland, Washington. 
APPENDIX A

CONVERSION UNITS USED 
APPENDIX A

\section{CONVERSION UNITS USED}

$\begin{array}{ll}\text { Gasoline } & 1 \mathrm{gal}=125,000 \mathrm{Btu} \\ \text { Diesel } & 1 \mathrm{gal}=140,000 \mathrm{Btu} \\ \text { LP Gas } & 1 \mathrm{gal}=95,500 \mathrm{Btu} \\ \text { Natural Gas } & 1 \mathrm{scf}=1,065 \mathrm{Btu} \\ \text { Electricity } & 1 \mathrm{kWh}=3,413 \mathrm{Btu} \\ \text { Fue1 0il } & 1 \mathrm{gal}=140,000 \mathrm{Btu} \\ \text { Coal } & 1 \mathrm{ton}=25.5 \times 10^{6} \mathrm{Btu} \\ \text { Fertilizer } & 1 \mathrm{ton}=34 \times 10^{6} \mathrm{Btu} \\ \text { Pesticides } & 1 \text { ton }=230 \times 10^{6} \mathrm{Btu}\end{array}$


.

, 
APPENDIX B

CHARACTERIZATION OF U.S. AGRICULTURE 
TABLE B.1. Average Farm Size (Regional), 159 Acres (Million Btu's/Average Farm)



(a) Each total assumes that entire farm (159 acres) is planted to corn grain or corn silage or soybeans, etc. 
TABLE B.2. Average Farm Size (Region 2), 244 Acres (Million Btu's/Average Farm)

\begin{tabular}{|c|c|c|c|c|c|c|c|c|}
\hline & & & & Winter & & & Sors & lum \\
\hline & Grain & Silage & Soybeans & Wheat & Hay & Cotton & Grain & Silage \\
\hline Gasoline & 188 & 255 & 328 & 126 & 148 & 263 & 209 & 229 \\
\hline Diese 1 & 147 & 335 & 435 & 189 & 1 & 683 & 320 & 351 \\
\hline LPG & 54 & 73 & 34 & 7 & 24 & 56 & 37 & 41 \\
\hline Natural Gas & 22 & 30 & 14 & 0 & 15 & 4 & 34 & 38 \\
\hline Electricity & 6 & 8 & 8 & 3 & 6 & 9 & 4 & 5 \\
\hline Fertilizers & 806 & 1005 & 113 & 610 & 664 & 757 & 595 & 526 \\
\hline Chemicals (Pesticides) & 25 & 25 & 63 & 2 & -- & 937 & 81 & 73 \\
\hline Other & 18 & 24 & $\underline{0}$ & $\underline{0}$ & $\underline{0}$ & $\underline{0}$ & $\underline{2}$ & $\underline{2}$ \\
\hline Total & 1366 & 1755 & 995 & 937 & 858 & 2709 & 1282 & 1265 \\
\hline Average Acres & 20.7 & 2.4 & 127.3 & 11.4 & 27.2 & 30.0 & 2.9 & 0.8 \\
\hline Total these crops & & & 222.7 & & & & & \\
\hline Total other crops & & & 21.3 & & & & & \\
\hline
\end{tabular}


TABLE B.3. Average Farm Size (Region 3), 219 Acres (Million Btu's/Average Farm)

\begin{tabular}{|c|c|c|c|c|c|c|c|c|}
\hline & & $r n$ & & Winter & & & Sorg & \\
\hline & Grain & Silage & Soybeans & Wheat & Hay & Cotton & Grain & Silage \\
\hline Gasoline & 76 & 77 & 216 & 166 & 233 & 205 & 241 & 280 \\
\hline Diesel & 258 & 261 & 172 & 34 & 9 & 377 & 146 & 170 \\
\hline LPG & 297 & 301 & 13 & 20 & 32 & 14 & 68 & 79 \\
\hline Natural Gas & 17 & 18 & 2 & -- & 11 & 0 & 13 & 16 \\
\hline Electricity & 14 & 14 & 5 & 5 & 3 & 4 & 7 & 8 \\
\hline Fertilizers & 904 & 901 & 46 & 431 & 493 & 414 & 565 & 663 \\
\hline Chemicals (Pesticides) & 56 & 56 & 24 & -- & 0 & 747 & 28 & 28 \\
\hline Other & 4 & 4 & 0 & $\underline{0}$ & $\underline{0}$ & $\underline{0}$ & 1 & 1 \\
\hline Total & 1626 & 1632 & 478 & 655 & 781 & 1761 & 1069 & 1245 \\
\hline Average Acres & 96 & 3 & 75.7 & 17.2 & 25.1 & 0.7 & 2.5 & 0.2 \\
\hline Total these crops & & & 220.4 & & & & & \\
\hline Total other crops & & & 0 & & & & & \\
\hline
\end{tabular}


TABLE B.4. Average Farm Size (Region 4), 206 Acres (Million Btu's/Average Farm)

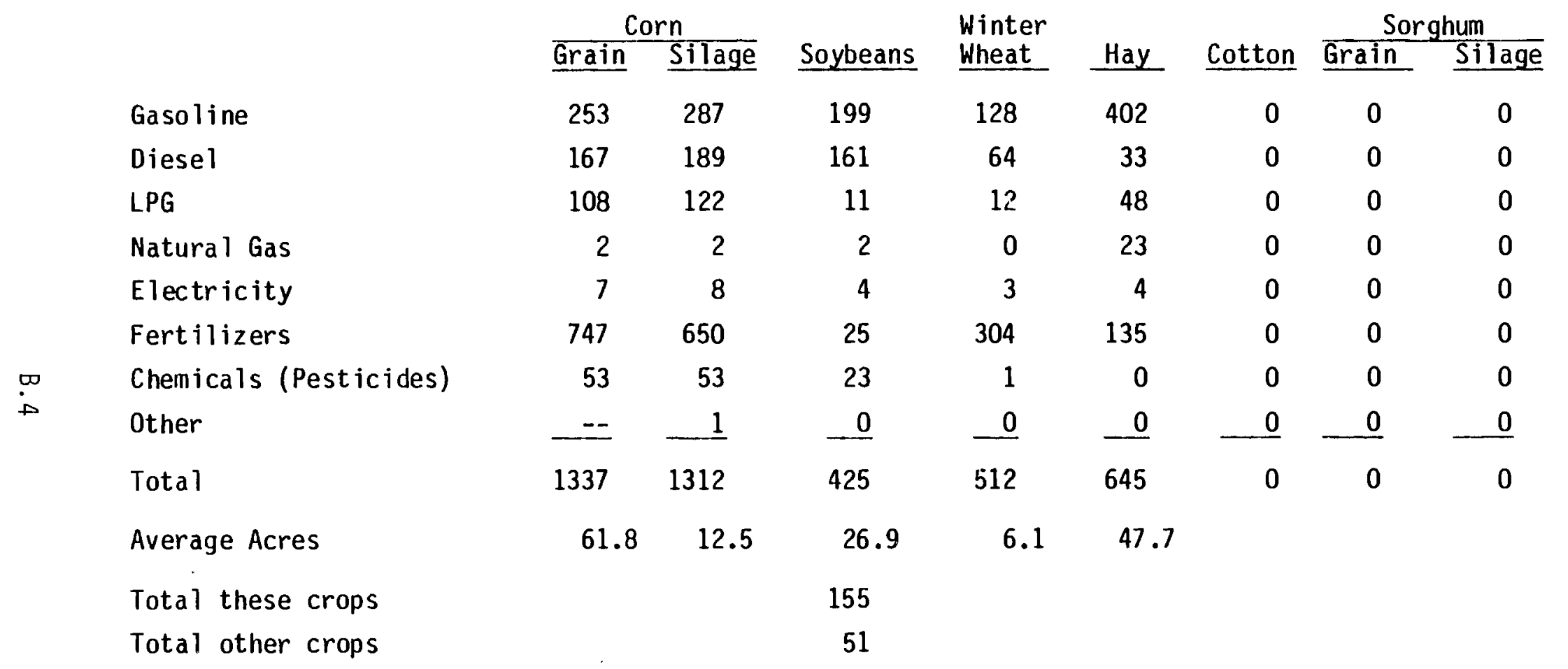


TABLE B.5. Average Farm Size (Region 5), 852 Acres (Million Btu's/Average Farm)

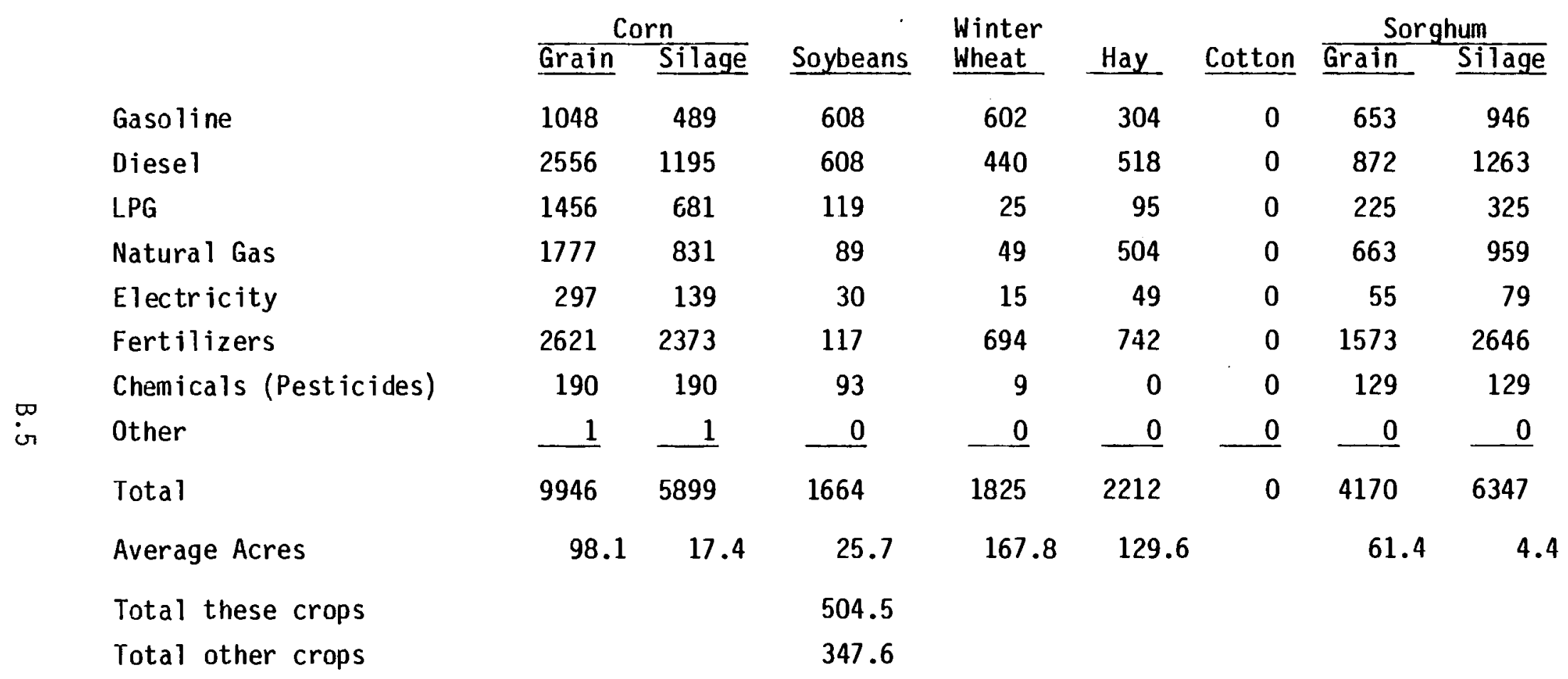


TABLE B.6. Average Farm Size (Region 6), 571 Acres (Million Btu's/Average Farm)

\begin{tabular}{|c|c|c|c|c|c|c|c|c|}
\hline & & $\mathrm{rn}$ & & Winter & & & Sor & $\operatorname{lum}_{\mathrm{s}}$ \\
\hline & Grain & Silage & Soybeans & Wheat & Hay & Cotton & Grain & Silage \\
\hline Gasoline & 594 & 977 & 445 & 392 & 572 & 275 & 617 & 670 \\
\hline Diesel & 773 & 1272 & 519 & 396 & 119 & 563 & 724 & 787 \\
\hline LPG & 268 & 442 & 78 & 50 & 107 & 87 & 179 & 195 \\
\hline Natural Gas & 3219 & 5297 & 1189 & 465 & 457 & 993 & 2016 & 2189 \\
\hline Electricity & 232 & 381 & 85 & 42 & 39 & 77 & 149 & 162 \\
\hline Fertilizers & 2928 & 2882 & 533 & 843 & 1 & 750 & 1240 & 1935 \\
\hline Chemicals (Pesticides) & 83 & 83 & 83 & 2 & 0 & 2359 & 218 & 218 \\
\hline Other & $\underline{0}$ & $\underline{0}$ & $\underline{0}$ & 0 & 0 & $\underline{0}$ & $\underline{0}$ & $\underline{0}$ \\
\hline Total & 8097 & 11334 & 2932 & 2190 & 1295 & 5104 & 5143 & 6156 \\
\hline Average Acres & 28.4 & 2.5 & 17.7 & 229.3 & 65.5 & 116.8 & 87.2 & 2.2 \\
\hline Total these Crops & & & 549.6 & & & & & \\
\hline Total other Crops & & & 21.4 & & & & & \\
\hline
\end{tabular}


TABLE B.7. Average Farm Size, 2570 Acres (Mil7ion Btu's/Average Farm)

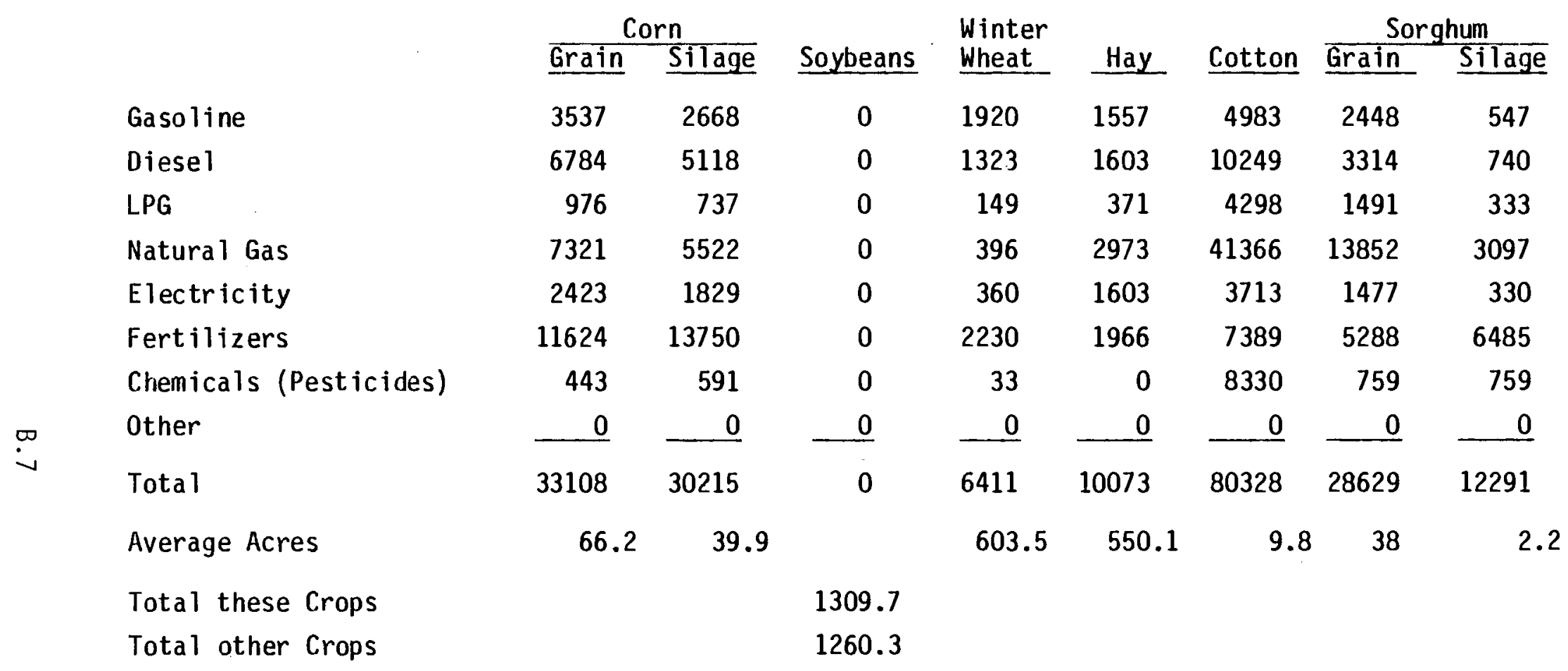


TABLE B.8. Average Farm Size (Region 8), 1907 Acres (Million Btu's/Average Farm)

\begin{tabular}{|c|c|c|c|c|c|c|c|c|}
\hline & \multicolumn{2}{|c|}{ Corn } & \multirow[b]{2}{*}{ Soybeans } & \multirow{2}{*}{$\begin{array}{l}\text { Winter } \\
\text { Wheat }\end{array}$} & \multirow[b]{2}{*}{ Hay } & \multirow[b]{2}{*}{ Cotton } & \multicolumn{2}{|c|}{ Sorghum } \\
\hline & Grain & Silage & & & & & Grain & Silage \\
\hline Gasoline & 1650 & 1384 & 0 & 467 & 1322 & 2416 & 1182 & 667 \\
\hline Diesel & 4256 & 3572 & 0 & 383 & 397 & 4613 & 1709 & 965 \\
\hline LPG & 71 & 59 & 0 & 27 & 158 & 0 & 128 & 72 \\
\hline Natural Gas & 782 & 656 & 0 & 299 & 2859 & 58856 & 10084 & 5694 \\
\hline Electricity & 4190 & 3515 & 0 & 360 & 6604 & 5616 & 6230 & 3518 \\
\hline Fertilizers & 11624 & 13750 & 0 & 2230 & 1966 & 7389 & 5288 & 6485 \\
\hline Chemicals (Pesticides) & 236 & 236 & 0 & 31 & 0 & 3665 & 235 & 235 \\
\hline Other & $\begin{array}{l}0 \\
\end{array}$ & $\underline{0}$ & $\underline{0}$ & $\underline{0}$ & $\underline{0}$ & $\underline{0}$ & $\underline{0}$ & $\underline{0}$ \\
\hline Total & 19677 & 20721 & 0 & 7919 & 11660 & 30174 & 28945 & 11328 \\
\hline Average Acres & 30.5 & 25.1 & & 433 & 327.2 & 164.0 & 19 & 1 \\
\hline Total these Crops & & & 999.9 & & & & & \\
\hline Total other Crops & & & 907 & & & & & \\
\hline
\end{tabular}


TABLE B.9. Energy in Thousands of Btu's per Milk Cow by Fuel Type

\begin{tabular}{|c|c|c|c|c|c|c|c|c|}
\hline Region & 1 & 2 & 3 & 4 & 5 & 6 & 7 & 8 \\
\hline Gasoline & 2232 & 2738 & 2464 & 2165 & 2645 & 3038 & 1711 & 2950 \\
\hline Diesel & 0 & 0 & 0 & 0 & 0 & 0 & 0 & 0 \\
\hline LPG & 559 & 944 & 701 & 342 & 818 & 1084 & 633 & 1068 \\
\hline Natural Gas & 0 & 0 & 0 & 0 & 0 & 0 & 0 & 0 \\
\hline Electrical & 1592 & 1398 & 1481 & 1688 & 1384 & 1304 & 870 & $\underline{1517}$ \\
\hline Total & 4383 & 5080 & 4646 & 4195 & 4847 & 5426 & 3214 & 5535 \\
\hline
\end{tabular}


PNL-3981

DISTRIBUTION

UC-93

No. of

Copies

OFFSITE

A. A. Churm

DOE Patent Division

2 DOE Technical Information Center

9800 S. Cass Avenue

Argonne, IL 60439

Dr. J. L. Butler

Manager

SEA Southern Agricultural

Energy Center

Tifton, Georgia 31793

Mr. E. F. Olver

Office of the Assistant Director

Special Programs

United States Department of Agriculture

Washington, D.C. 20250

Wanda Porterfield

Department of Energy

Forrestal Building

Washington, D.C. 20585

Mr. W. Ralph Nave

U.S. Department of Agriculture

Science and Education Administration

Beltsvi11e, MD 20705

Mr. John Archbold

Foxlease Farms of Archbold Investment Co.

Upperville, VA 22176

Mr. Tom Snider

CENTEC

11800 Sunrise Valley Drive

Reston, VA 22091

Mr. David A. Malish

Sumx Corp.

P.0. Box 14864

1300 E. Braker Lane

Austin, TX 78761

Mr. William E. Splinter

Dept. of Agricultural Engineering

University of Nebraska

Lincoln, NE 68583 


\section{Distribution (cont'd)}

Mr. Richard S. Combes

Director, Technology Applications Laboratory

Engineering Experiment Station

Georgia Institute of Technology

Atlanta, GA 30332

Dr. G. Pratt

Agricultural Engineering Department

North Dakota State University

P.0. Box 5435

Fargo, ND 58105

Dr. Alex G. Alexander

Center for Energy and Environmental Research

University of Puerto Rico

Caparra Heights Station

San Juan, Puerto Rico 00935

Dr. Larry P. Walker

Agricultural Engineering Department

Cornell University

Ithaca, NY 14853

Dr. David Pinkerton

Energy Management Corp.

19208 S. Vermont

Gardena, CA 90248

ONSITE

DOE Richland Operations Office

H. E. Ransom

17 Pacific Northwest Laboratory

D. E. Eakin (5)

M. A. Clark

K. I. Johnson

L. K. Inaba

P. M. Molton

G. L. Wilfert

Publishing Coordination (2)

Technical Information (5) 